\title{
A Simulation Study of Infiltration Into Surficial Sediments at the Subsurface Disposal Area, Idaho National Engineering Laboratory
}

\author{
P. Martian \\ S. O. Magnuson
}

Published April 1994

\begin{abstract}
Idaho National Engineering Laboratory
EG\&G Idaho, Inc. Idaho Falls, Idaho 83415
\end{abstract}




\section{DISCLAIMER}

This report was prepared as an account of work sponsored by an agency of the United States Government. Neither the United States Government nor any agency thereof, nor any of their employees, make any warranty, express or implied, or assumes any legal liability or responsibility for the accuracy, completeness, or usefulness of any information, apparatus, product, or process disclosed, or represents that its use would not infringe privately owned rights. Reference herein to any specific commercial product, process, or service by trade name, trademark, manufacturer, or otherwise does not necessarily constitute or imply its endorsement, recommendation, or favoring by the United States Government or any agency thereof. The views and opinions of authors expressed herein do not necessarily state or reflect those of the United States Government or any agency thereof. 


\section{DISCLAIMER}

Portions of this document may be illegible in electronic image products. Images are produced from the best available original document. 


\section{ABSTRACT}

Soil moisture monitoring data in the surficial sediments at the Subsurface Disposal Area (SDA) at the Idaho National Engineering Laboratory were used to calibrate two numerical infiltration models. The calibration was performed with the ultimate goal of providing a reliable estimate of hydraulic properties and infiltration amounts to be used in other modeling efforts. Two neutron probe access tubes and a tensiometer nest were monitored from 1986 to 1990 and again during 1993. The field measurements of moisture content and matric potential inside the SDA were used as calibration data for the two locations. The two locations showed vastly different behavior, which was well captured in the models. The average root mean square error between simulated and measured moisture contents over the simulation period was 0.03 and 0.06 for the two locations. The hydraulic parameters resulting from the calibration compared favorably with laboratory and field scale estimates.

The simulation results also provided the opportunity to partially explain infiltration and redistribution processes occurring at the SDA. The underlying fractured basalt appears to behave similar to a capillary barrier. This behavior inhibits moisture movement into the underlying basalts until moisture contents in the overlying silts approach saturation. As a result, a large proportion of recharge occurring at the SDA may be due to spring snowmelt, when the surficial sediments become nearly saturated. The results also indicated that a unit gradient boundary condition (free drainage due to gravity) at the bottom of the silts is not appropriate because of the very low relative hydraulic conductivity of the basalts. Finally, the amount of water moving into the SDA subsurface from spring snowmelt appears larger than cumulative snowfall, indicating that snow drifting due to local topography as well as current snow management practices may have a substantial influence on local infiltration. 


\section{CONTENTS}

ABSTRACT $\ldots \ldots \ldots \ldots \ldots \ldots \ldots \ldots \ldots \ldots \ldots \ldots \ldots \ldots \ldots \ldots \ldots \ldots$

ACKNOWLEDGMENTS $\ldots \ldots \ldots \ldots \ldots \ldots \ldots \ldots \ldots \ldots \ldots \ldots \ldots \ldots$ viii

1. INTRODUCTION $\ldots \ldots \ldots \ldots \ldots \ldots \ldots \ldots \ldots \ldots \ldots \ldots \ldots \ldots \ldots \ldots \ldots \ldots$

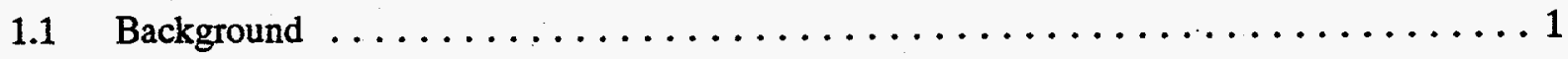

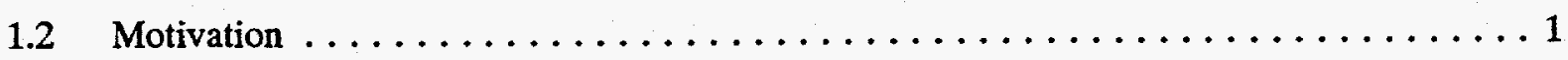

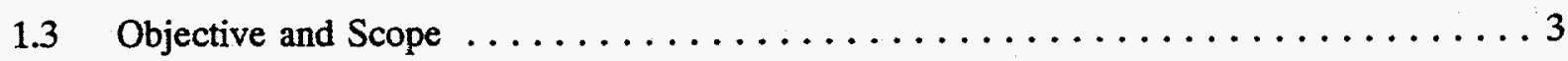

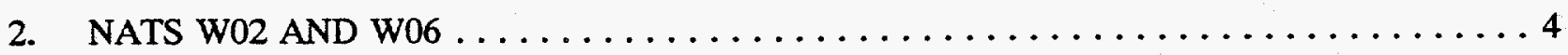

2.1 Geology and Climatic Conditions $\ldots \ldots \ldots \ldots \ldots \ldots \ldots \ldots \ldots \ldots \ldots \ldots$

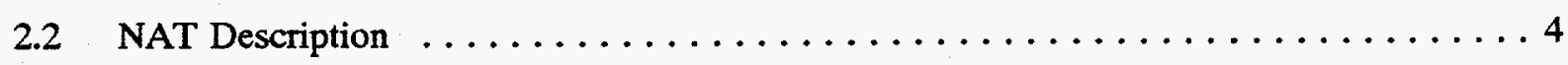

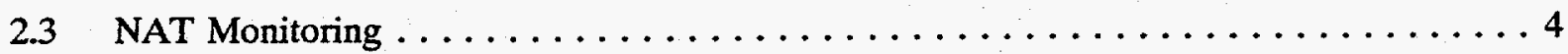

3. INVESTIGATION OF LATERAL FLOW $\ldots \ldots \ldots \ldots \ldots \ldots \ldots \ldots \ldots \ldots \ldots \ldots \ldots$

4. MODELING APPROACH $\ldots \ldots \ldots \ldots \ldots \ldots \ldots \ldots \ldots \ldots \ldots \ldots \ldots$

4.1 Infiltration and Redistribution Physics $\ldots \ldots \ldots \ldots \ldots \ldots \ldots \ldots \ldots \ldots$

$4.2 \quad$ Numerical Model $\ldots \ldots \ldots \ldots \ldots \ldots \ldots \ldots \ldots \ldots \ldots \ldots \ldots \ldots$

4.2.1 Hydraulic Properties $\ldots \ldots \ldots \ldots \ldots \ldots \ldots \ldots \ldots \ldots \ldots \ldots$

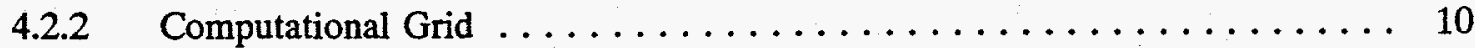

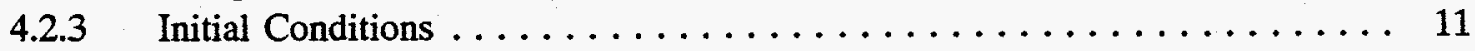

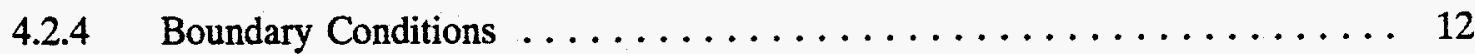

4.2 .5 Model Calibration $\ldots \ldots \ldots \ldots \ldots \ldots \ldots \ldots \ldots \ldots \ldots \ldots \ldots \ldots$

5. MODELING RESULTS $\ldots \ldots \ldots \ldots \ldots \ldots \ldots \ldots \ldots \ldots \ldots \ldots \ldots \ldots$

5.1 Evaluation of Calibration Results $\ldots \ldots \ldots \ldots \ldots \ldots \ldots \ldots \ldots \ldots \ldots$

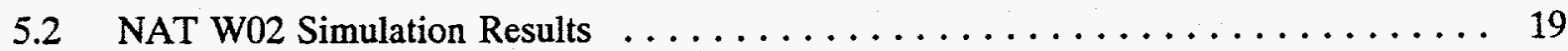

5.2.1 Comparison of Field and Simulation Results . . . . . . . . . . . 19

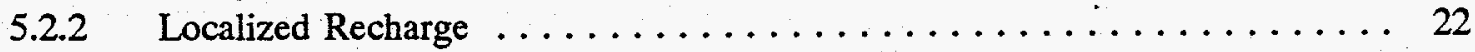

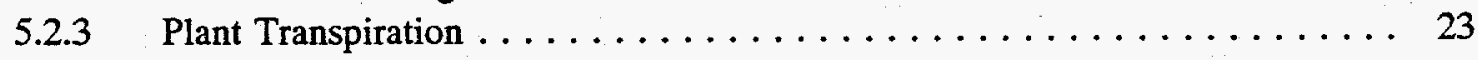




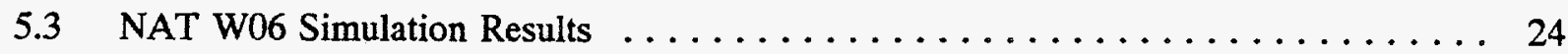

5.3.1 Comparison of Field and Simulation Results . . . . . . . . . . . . . 24

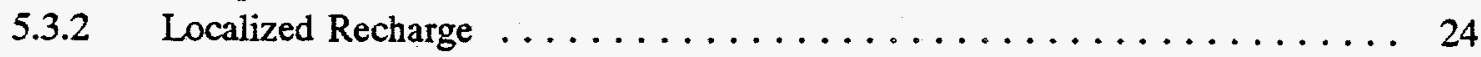

5.3.3 Comparison with Laboratory Scale Properties . . . . . . . . . . . 30

5.3.4 Comparison with Field Scale Properties $\ldots \ldots \ldots \ldots \ldots \ldots \ldots \ldots \ldots \ldots$

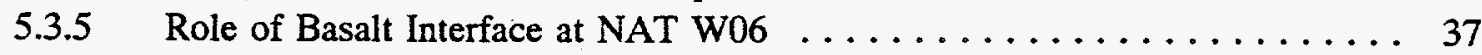

6. CONCLUSIONS AND FUTURE DIRECTIONS $\ldots \ldots \ldots \ldots \ldots \ldots \ldots \ldots \ldots \ldots$

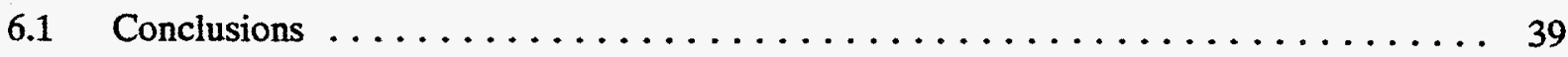

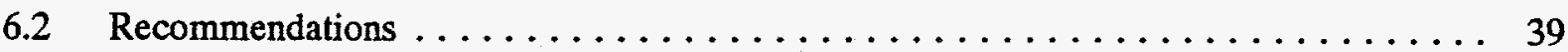

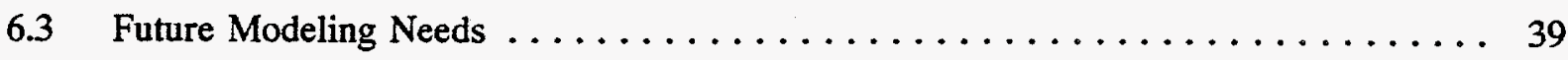

7. REFERENCES $\ldots \ldots \ldots \ldots \ldots \ldots \ldots \ldots \ldots \ldots \ldots \ldots \ldots \ldots \ldots \ldots \ldots \ldots \ldots \ldots \ldots \ldots$

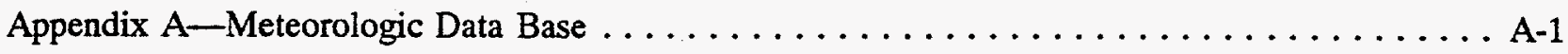

Appendix B-UNSAT-H Simulation Input Data Decks $\ldots \ldots \ldots \ldots \ldots \ldots \ldots \ldots \ldots$ B-1

FIGURES

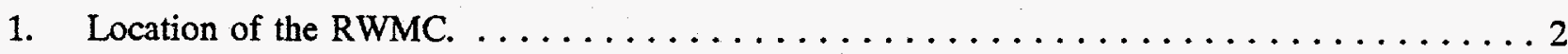

2. Simulation soil profiles for NATs W02 and W06. .................. 11

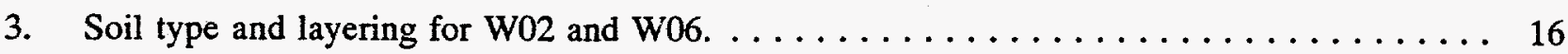

4. NAT W02 field and simulation moisture contents for 1987 to $1989 \ldots \ldots \ldots \ldots \ldots \ldots 20$

5. NAT W02 field and simulation moisture contents for 1990 to $1993 \ldots \ldots \ldots \ldots \ldots .21$

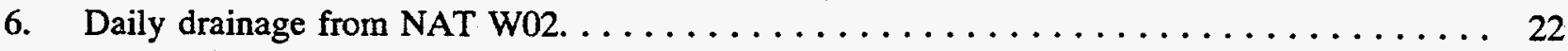

7. NAT W06 field and simulation moisture contents for 1987 to $1989 \ldots \ldots \ldots \ldots \ldots 25$

8. NAT W06 field and simulation moisture contents for 1990 to $1993 \ldots \ldots \ldots \ldots \ldots \ldots 26$

9. NAT W06 field and simulation tensions for 1987 to $1989 \ldots \ldots \ldots \ldots \ldots \ldots \ldots$. 27

10. NAT W06 field and simulation tensions for 1990 to $1993 \ldots \ldots \ldots \ldots \ldots \ldots \ldots$

11. Drainage from NAT W06 (two different vertical scales). . . . . . . . . . . . . 29 
12. NAT W06 field and simulation moisture contents using field estimated parameters for 1987 to 1989

13. NAT W06 field and simulation moisture contents using field estimated parameters for 1990 and 1989

14. Comparison of basalt and sand soil moisture curves. $\ldots \ldots \ldots \ldots \ldots \ldots \ldots \ldots \ldots$

15. Sediment moisture contents and daily drainage during $1993 \ldots \ldots \ldots \ldots \ldots \ldots \ldots \ldots$

\section{TABLES}

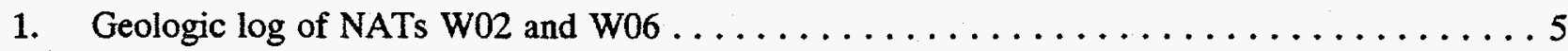

2. Infiltrated water amounts at various depths for NATs W02 and W06 (1987-1989) $\ldots \ldots \ldots 7$

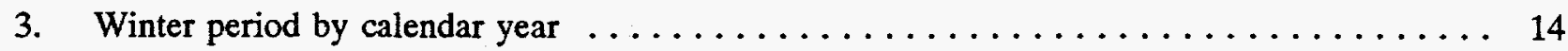

4. Base and modified snowpack water equivalent $\ldots \ldots \ldots \ldots \ldots \ldots \ldots \ldots \ldots$

5. Hydraulic properties for $w_{02} \ldots \ldots \ldots \ldots \ldots \ldots \ldots \ldots \ldots \ldots \ldots \ldots \ldots$

6. Hydraulic properties for W06 $\ldots \ldots \ldots \ldots \ldots \ldots \ldots \ldots \ldots \ldots \ldots \ldots \ldots \ldots \ldots$

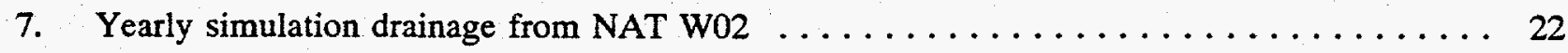

8. Yearly simulation drainage from NAT W06 $\ldots \ldots \ldots \ldots \ldots \ldots \ldots \ldots \ldots \ldots \ldots \ldots$

9. Laboratory scale hydraulic properties $\ldots \ldots \ldots \ldots \ldots \ldots \ldots \ldots \ldots \ldots \ldots \ldots$

10. Simulation hydraulic properties $\ldots \ldots \ldots \ldots \ldots \ldots \ldots \ldots \ldots \ldots \ldots \ldots \ldots \ldots$

11. Field scale hydraulic properties $\ldots \ldots \ldots \ldots \ldots \ldots \ldots \ldots \ldots \ldots \ldots \ldots \ldots \ldots$

12. Simulation hydraulic properties $\ldots \ldots \ldots \ldots \ldots \ldots \ldots \ldots \ldots \ldots \ldots \ldots \ldots \ldots \ldots$ 


\section{ACKNOWLEDGMENTS}

The authors wish to thank the individuals who provided assistance with this work. First and foremost, we wish to thank John A. Logan for his forethought and willingness to support research modeling efforts. We also wish to thank Deborah L. McElroy for her assistance in interpreting the field data used by this work and for her extensive review and comments on an early draft of this document. Lastly, the authors also acknowledge Dr. Annette Schafer-Perini for providing insight as well as assistance with the visual data analysis of the many computer simulations performed during this work. 


\section{A Simulation Study of Infiltration into Surficial Sediments at the Subsurface Disposal Area, Idaho National Engineering Laboratory}

\section{INTRODUCTION}

\subsection{Background}

Since the mid-1950s, the Radioactive Waste Management Complex (RWMC), located in the southwestern portion of the Idaho National Engineering Laboratory (INEL), has been used for storage and disposal of wastes generated by national defense programs and reactor research activities. The INEL is located along the western edge of the Eastern Snake River Plain, which encompasses most of the southeastern portion of Idaho and occupies approximately $890 \mathrm{mi}^{2}$. The RWMC consists of about 144 acres of a shallow depression surrounded by low hills and is divided into two major areas: (a) the Subsurface Disposal Area (SDA) in which low-level radioactive and other hazardous wastes have been buried in shallow pits excavated in the surficial sediments and (b) the Transuranic Storage Area in which transuranic wastes are stored above ground in covered pads. The location of the RWMC within the INEL and Snake River Plain is illustrated in Figure 1.

\subsection{Motivation}

Infiltration is the process in which surface water enters the soil. Infiltrated water moving down through wastes in the soil, becoming contaminated, and eventually reaching the aquifer is one of the most realistic scenarios for aquifer contamination at the SDA. Therefore, infiltration is an important factor controlling contaminant migration because it is responsible for the amount of dissolution and transport of contaminants away from the waste disposal pits.

Because of the possibility of serious consequences of atmosphere and aquifer contamination if wastes in the disposal pit migrate, a significant amount of effort has been devoted to investigate potential pathways for contaminant migration away from the SDA, including both field and modeling studies. One such field study consisted of a vadose zone monitoring program, which was conducted to characterize infiltration at the SDA (McElroy, 1990). From 1985 to 1987, a network of vadose zone instruments were installed at the SDA. The instrumentation included neutron probe access tubes (NATs) and tensiometers. Two NATs (W02 and W06) were regularly monitored for moisture content and matric potentials. The locations of NAT W02 and W06 within the SDA are illustrated in Figure 1. In addition to infiltration amount estimates, the monitoring program resulted in a substantial data base that can be used for model development and calibration.

During previous RWMC infiltration modeling studies, no attempts were made to calibrate the numerical models used because no quantitative data were available (Baca et al., 1992). They 


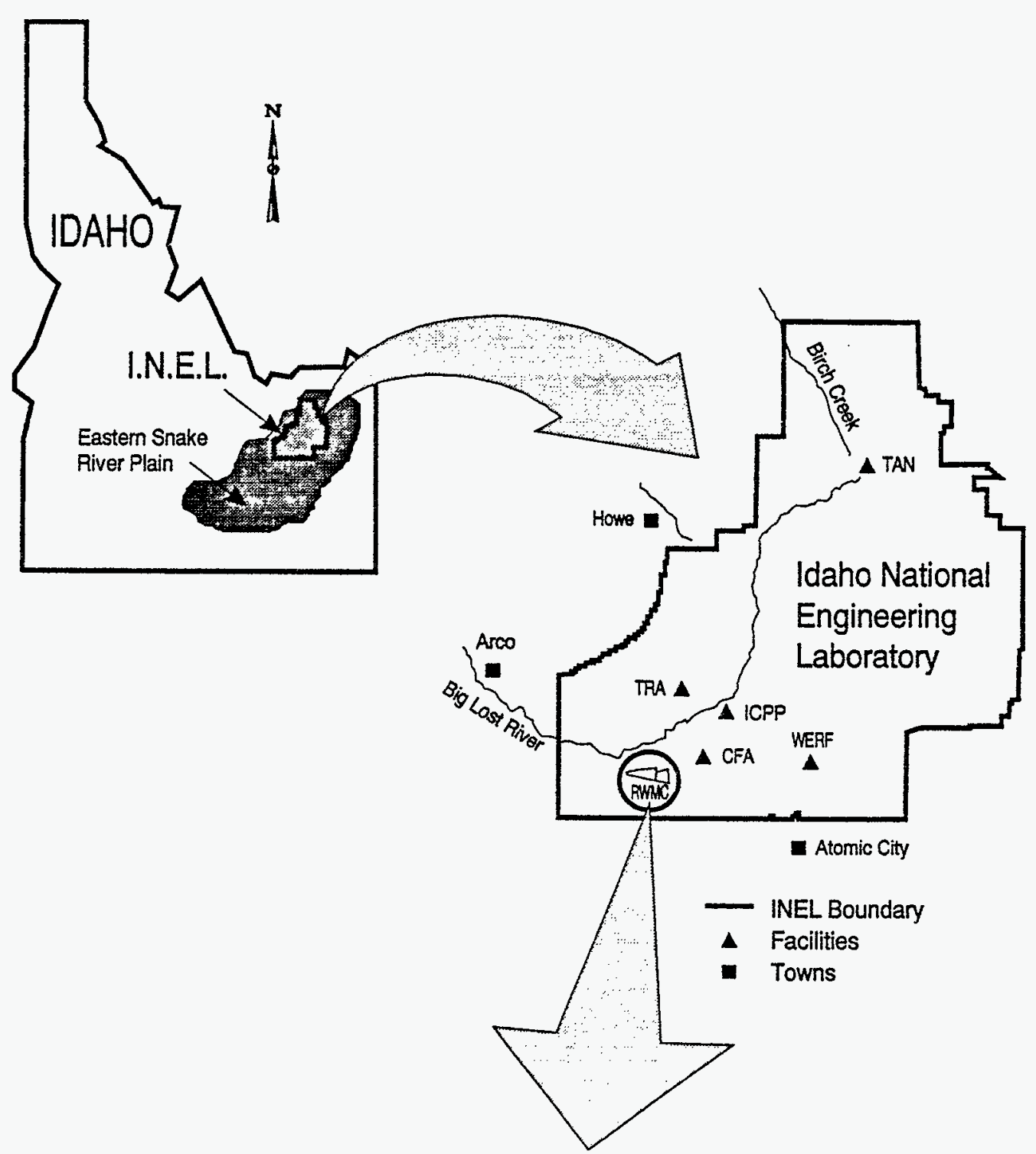

Radioactive Waste Management Complex

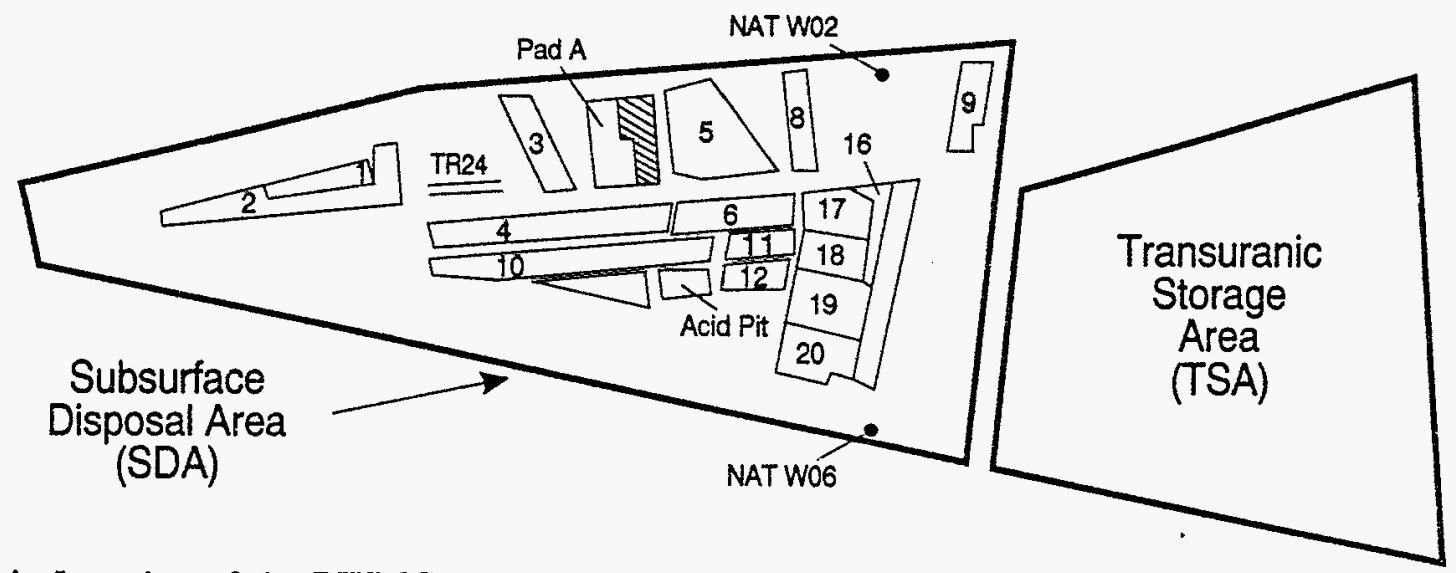

Figure 1. Location of the RWMC. 
were constrained to rely on the assumption of uniform infiltration rates across the SDA that were equivalent to the amount of precipitation occurring at either the nearby Central Facilities Area (CFA) weather station or the National Weather Service Station located in Pocatello, Idaho. Recent analysis of data gathered in the vadose zone monitoring program indicates that a substantially greater amount of water infiltrated into the underlying basalts than is shown in the CFA precipitation measurements. McElroy (1993) estimated that $56 \mathrm{~cm}$ and $24 \mathrm{~cm}$ of water infiltrated at NATs W06 and W02, respectively, during the spring of 1993 , while only $12.2 \mathrm{~cm}$ of precipitation occurred between November 1992 and March 1993 at CFA. Additionally, the snowpack water equivalent measurements at NATs W02 and W06 taken early in 1993 were also higher than the cumulative precipitation measurements at CFA. McElroy (1993) measured maximum water equivalent snowpack amounts to be over $20 \mathrm{~cm}$ at both NATs.

Large recharge events due to localized infiltration, as seen in W06, could enhance contaminant migration in these areas. This information indicates that there is a need to use more detailed models for predicting SDA infiltration amounts. The moisture content and matric potential field measurements collected by McElroy (1993) provide a readily available source of data to calibrate two locationspecific models.

\subsection{Objective and Scope}

A calibrated simulation study of moisture infiltration at NAT W02 and W06 was conducted to obtain a reliable estimate of hydraulic parameters, which then could be used to extend the simulation period backwards and forwards in time. Extending simulation back in time permits evaluation of water movement, which previous disposal practices were subject to; extending the simulation forward in time with estimated meteorological conditions allows evaluation of future conditions.

The objective of the simulation study is to obtain a good match between simulated and field estimates of moisture contents and matric potentials at W06, and moisture contents at W02. Once this objective is met, the calibrated simulations will provide (a) a reliable estimate of the amount and timing of net infiltration at the two locations, (b) a validation of hydraulic properties measured from W06 core samples presented in McElroy and Hubbell (1990) and field scale estimates of hydraulic properties presented in McElroy, and (c) an insight into the soil physics occurring at the SDA (i.e., explain the role of the surface soil-basalt interface and the presence of perched water in some of the NATs).

Section 2 of this report contains a description of NATs W02 and W06 as well as the monitoring program. Section 3 discusses an investigation of lateral flow into NAT W02 and W06 areas. Section 4 presents the modeling approaches including the methodology used to calibrate the numerical model at NATs W02 and W06, and results of the model calibration are discussed in Section 5. Lastly, Section 6 presents the conclusions and future modeling needs identified by this work.

a. Unpublished work, 1994. 


\section{NATS W02 AND W06}

\subsection{Geology and Climatic Conditions}

Much of the Snake River Plain subsurface consists of a thin layer of sediments composed of silt, sand, clay, and gravel ranging in thickness from 2 to $24 \mathrm{ft}$, which are underlain by a complex sequence of basalt flows. The basalt flows continue down to through the aquifer, which is located approximately $120 \mathrm{~m}$ below the surface. The basalts are often fractured, especially near the top and bottom of each layer and are separated by discontinuous sedimentary interbeds.

The climate on the INEL is that of a semi-arid, high desert region and is characterized by large daily and seasonal temperature variations. During the summer, low humidity, clear skies, and high temperatures result in high evaporation rates while average winter temperatures remain below freezing for 2 to 3 months, essentially preventing most evapotranspiration during the winter. The average annual temperature is approximately $42^{\circ} \mathrm{F}$ and the average annual precipitation is about $22 \mathrm{~cm}$ with $30 \%$ falling as snow (Clawson et al., 1989). Most of the precipitation occurs during the late spring or early fall, with an occasional heavy thunderstorm occurring during the summer. Precipitation usually exceeds evaporation from October through May, and evaporation exceeds precipitation during June though September (Anderson et al., 1991).

\subsection{NAT Description}

NATs W02 and W06 were installed in the fall of 1986. The neutron access holes were handaugured to the underlying basalt at $14.5 \mathrm{ft}$ and $10.5 \mathrm{ft}$ below land surface for holes W02 and W06, respectively. Carbon steel pipes were then installed leaving $2 \mathrm{ft}$ of pipe extending above the ground (Hubbell et al., 1987). In addition to the neutron access holes, three tensiometer nests were installed at 3-, 6-, and 9-ft depths in a borehole located approximately $4 \mathrm{ft}$ east of NAT W06. Table 1 provides a geologic description of layering in NAT W02 and the tensiometer access hole near NAT W06, which was recorded during their construction.

\subsection{NAT Monitoring}

In situ soil moisture and matric potential data at the NAT W02 and W06 locations were collected monthly from November 1986 to November 1990. In December 1992, neutron probe access tube monitoring was resumed with more frequent monitoring during the spring when the majority of infiltration occurred from snowmelt and spring rains. The neutron probes were monitored at least once a week prior to the spring snowmelt in March 1993, and monitored every other day during the snowmelt and subsequent infiltration in March and early April. As the soil profile began to dry, monitoring frequency was reduced to about once a week in April through June, twice a month in July, and once a month during August and September (McElroy, 1993). 
Table 1. Geologic log of NATs W02 and W06 (McElroy, 1993).

\begin{tabular}{|c|c|c|c|c|}
\hline \multirow{2}{*}{\multicolumn{2}{|c|}{$\begin{array}{l}\text { W02 } \\
\text { Description }\end{array}$}} & \multicolumn{3}{|c|}{ W06 } \\
\hline & & $\begin{array}{c}\text { Depth } \\
(\mathrm{ft})\end{array}$ & Description & \\
\hline 0.0 & Silty clay & 0.0 & Sandy silt & \\
\hline 2.5 & Silt & 1.7 & Sandy silt & \\
\hline 4.3 & Sandy silt & 2.8 & Sandy silt & \\
\hline 6.0 & Sand & 4.3 & Sandy silt & \\
\hline 7.7 & Silt & 6.0 & Sandy silt & \\
\hline 9.5 & Silt & 7.7 & Clayey sandy silt & \\
\hline 11.2 & Silt & 9.3 & Sandy silt & \\
\hline 13.0 & Clayey silt & 11.0 & Sandy silt & 8 \\
\hline 14.7 & Basalt & 11.8 & Basalt & \\
\hline
\end{tabular}




\section{INVESTIGATION OF LATERAL FLOW}

Prior to performing the simulations, an investigation was conducted to determine if and at which depth lateral water movement may be occurring at the W02 and W06 NAT locations by analyzing the field measurements of moisture content. The net amount of water inflow or outflow at each monitored depth can be roughly estimated by summing the differences in moisture contents between each monitoring date using the equation

$$
I_{i}=\sum_{t=1}^{t=t_{t}} \sigma\left(\theta_{i, t+1}-\theta_{i, t}\right)
$$

where

$$
\begin{aligned}
& I=\text { net water inflow or outflow at individual depths } \\
& \theta=\text { moisture content at each depth interval } \\
& t^{\prime}=\text { times at which measurements were taken } \\
& 6=\text { distance between moisture content recordings. }
\end{aligned}
$$

The maximum infiltration amounts were found by simply retaining the largest single difference from the equation for each depth; this is an attempt to quantify the amount of moisture that moved into the soil from the largest infiltration event (i.e., the spring snowmelt). The net and maximum flow amounts for each depth can then be used to estimate lateral flow by identifying areas of high and relatively low inflow. If a large maximum or net inflow occurred below areas of lower inflow, continuity would dictate that the infiltration would be a result of lateral flow.

The differencing was performed over the 1993 data, which extended between January 20 and October 11. The 1993 data were chosen because if any lateral flow did occur, it would most likely be due to the large and rapid spring snowmelt that occurred during 1993.

Results of the differencing (i.e., net and maximum and changes in moisture contents for 6-in. depth intervals at 1-ft increments) are presented in Table 2. Both net and maximum changes in moisture contents followed a generally decreasing trend with increasing depth in both NATs. These trends indicated that much of the infiltration occurs near the surface and also exits through the surface via evapotranspiration. The amounts by which net and maximum changes in moisture contents deviate from a decreasing trend are small compared to the gross infiltration amounts described in McElroy (1993). Furthermore, most areas that deviated from the decreasing infiltration with depth trend were in areas of relatively low conductivity with the exception of maximum infiltration in NAT W06. Lateral flow would most likely occur in areas of high conductivity immediately over areas of low conductivity. The appearance of higher infiltration amounts in low conductivity is probably due to water remaining longer in the low conductivity areas. These results suggest that lateral water movement does not appear to be a significant factor contributing to the increased infiltration occurring at NATs W02 or W06 during 1993.

Results of the differencing also indicate that the soil profiles in both NATs retained some of the water from the relatively large 1993 precipitation amount, which reflects the precipitation pattern previous to and during the period. The integration period consisted of a relatively wet year, which 
was proceeded by a dry year. Finally, it should be noted that this analysis for lateral flow is only a crude estimation. Steady-state lateral flow would not be seen by the differencing equation.

Table 2. Infiltrated water amounts at various depths for NATs W02 and W06 (1987-1989).

\begin{tabular}{|c|c|c|c|c|}
\hline \multirow{2}{*}{$\begin{array}{l}\text { Depth } \\
\text { (ft) }\end{array}$} & \multicolumn{2}{|c|}{$\begin{array}{l}\text { Net infiltrated water } \\
\text { (in.) }\end{array}$} & \multicolumn{2}{|c|}{$\begin{array}{l}\text { Maximum infiltrated water } \\
\text { (in.) }\end{array}$} \\
\hline & W02 & W06 & W02 & W06 \\
\hline 1.0 & 0.25 & 0.41 & 1.55 & 1.85 \\
\hline 2.0 & 0.29 & 0.46 & 1.44 & 1.34 \\
\hline 3.0 & 0.13 & 0.50 & 1.62 & 1.04 \\
\hline 4.0 & 0.05 & 0.46 & 0.20 & 1.09 \\
\hline 5.0 & 0.22 & 0.33 & 0.35 & 1.17 \\
\hline 6.0 & 0.17 & 0.25 & 0.26 & 1.25 \\
\hline 7.0 & 0.00 & 0.18 & 0.04 & 0.71 \\
\hline 8.0 & 0.00 & 0.14 & 0.04 & 0.67 \\
\hline 9.0 & 0.08 & 0.24 & 0.11 & 0.78 \\
\hline 10.0 & -0.02 & unknown & 0.05 & unknown \\
\hline 11.0 & 0.04 & unknown & 0.11 & unknown \\
\hline 12.0 & 0.02 & unknown & 0.07 & unknown \\
\hline 13.0 & -0.02 & unknown & 0.01 & unknown \\
\hline
\end{tabular}




\section{MODELING APPROACH}

To simulate infiltration, the underlying physical processes must be identified, and a suitable numerical model must be selected. Once a numerical model is chosen, input parameters representing the simulation site must be specified. These parameters include boundary conditions, initial conditions, model geometry, and soil hydraulic properties. This section contains a general discussion of infiltration and redistribution physics including the governing equation, the numerical model selected along with specification of the input parameters, and the methodology used in calibrating the model.

\subsection{Infiltration and Redistribution Physics}

Infiltration is the process by which surface water enters the soil. Redistribution is the process through which water made available from infiltration redistributes itself during infiltration and after the infiltration has stopped. After surface water has infiltrated into the soil, it redistributes itself in response to gravity and capillary forces. The redistribution process will ultimately partition the infiltrated water into a three-part water balance. These parts consist of (a) surface losses that are due evaporation and transpiration, (b) drainage that becomes aquifer recharge, and (c) storage that is water that remains in the vadose zone.

When water is applied in relatively small amounts, (i.e., at rates less than the soil's saturated conductivity), the water infiltrates as fast as it is applied, and the application rate controls the infiltration. However, as often is the case during spring snowmelt, application rates exceed the soil's capacity for infiltration, and the soil's hydraulic conductivity controls the infiltration rate after the initial soil wetting. In this latter case, the initial infiltration rate is relatively large and may even exceed the saturated hydraulic conductivity. This large initial infiltration rate is due to the extremely large matric potential gradients between the dry soil ahead of the wetting front and the moist soil behind the wetting front as well as the soil's capacity to store the initial water. Eventually, the infiltration rate will decrease with time because of pore infilling and eventually reach a steady-state rate equal to the soil's saturated hydraulic conductivity.

The partial differential equation governing unsaturated flow, including infiltration and redistribution, can be derived from the general mass conservation equation and Darcy's law as originally performed by Richards (1931). For the case of one-dimensional flow, Richards' equation is

$\mathrm{C}(\mathrm{h}) \frac{\partial \mathbf{h}}{\partial \mathrm{t}}=-\frac{\partial}{\partial z}\left[\mathrm{~K}(\mathrm{~h})\left(\frac{\partial \mathbf{h}}{\partial z}+1\right)\right]$

where

h = suction head

$\mathrm{C}(\mathrm{h})=$ specific moisture capacity, the slope of the soil moisture curve $\partial \theta / \partial \mathrm{h}$ in which $\theta$ is the volumetric moisture content

$\mathrm{z} \quad=$ depth into the soil

$\mathrm{t}=$ time

$\mathrm{K}(\mathrm{h})=$ relative hydraulic conductivity. 


\subsection{Numerical Model}

The UNSAT-H Version 2.01 computer code (Fayer and Jones, 1990) was chosen for the simulations in this study because of its ability to model infiltration as a function of meteorological conditions at semi-arid sites. The code uses an iterative finite-difference technique to solve a modified form of Richards' equation, which also accounts for water vapor diffusion. Specifically, the code has the ability to account for (a) liquid and vapor water movement, (b) heat transfer by conduction and convection, (c) evapotranspiration at the soil surface, and (d) transpiration by plants.

The UNSAT-H code has been verified and benchmarked by Baca and Magnuson (1990) and has been successfully applied to simulate moisture transport at several semi-arid locations (Fayer et al., 1992; Baca et al., 1992; Magnuson, 1993).

In order to solve Richards' equation, the UNSAT-H code must be supplied with four basic components. These components are soil hydraulic properties, computational grid, initial conditions, and boundary conditions. Each of these components will be discussed in turn.

\subsubsection{Hydraulic Properties}

Characterizing unsaturated flow requires three basic hydraulic properties for each material type identified in the simulation profile. These three properties are (a) the moisture characteristic curve, which is the relation between the matric potential and moisture content, (b) the hydraulic conductivity curve, which is the relation between the matric potential and the relative hydraulic conductivity, and (c) the saturated hydraulic conductivity.

Although obtaining soil hydraulic properties is one of the final objectives of this study, initial estimates of these properties were needed before beginning the calibration process. These initial estimates were obtained from hydrologic characterization of core samples taken from the SDA (McElroy and Hubbell, 1990; Bishop, 1991). These estimates were then revised as of part of the calibration process.

Points on the moisture characteristic curve and hydraulic conductivity curve are usually determined experimentally, and analytic curves are empirically curve fit to these data. The van Genuchten equations (van Genuchten, 1980) were used to represent these constitutive relationships. The equation for the characteristic curve is

$\theta=\theta_{\mathrm{I}}+\left(\theta_{\mathrm{s}}-\theta_{\mathrm{r}}\right)\left[1+(\alpha h)^{\mathrm{n}}\right]^{1-1 / \mathrm{h}}$

and the equation for the hydraulic conductivity curve is

$K(h)=K_{s} \frac{\left[1-(\alpha h)^{n-2}\left[1+(\alpha h)^{n}\right]^{-(1-1 / n)}\right]^{2}}{\left[1+(\alpha h)^{n}\right]^{(1-1 / h) / 2}}$ 
where

$\mathrm{h}=$ suction head

$\mathrm{K}_{\mathrm{s}}=$ saturated hydraulic conductivity

$\theta=$ volumetric moisture content

$\alpha=$ curve-fitting parameter

$\mathrm{n}=$ curve-fitting parameter

$\theta_{\mathrm{s}}=$ residual saturation

$\theta_{\mathrm{s}}=$ porosity.

\subsubsection{Computational Grid}

The general model domain is a one-dimensional vertical column. Soil layer profiles were constructed for NATs W02 and W06 by defining distinct soil layers and assigning hydraulic properties. Transition layers were then assigned between the main layers, and the hydraulic properties for these layers were linearly interpolated from the bounding layers.

Soil layering was determined by analyzing field estimates of soil moisture profiles. Low conductivity zones in soils typically have a higher moisture content because water tends to accumulate in these regions. This is primarily due to the restriction of water flow by the low conductivity zones. Laboratory analysis of core samples taken from surficial sediments and sedimentary interbeds of the SDA (McElroy and Hubbell, 1990) included two silt samples from NAT W06, which represented a relatively low and a somewhat higher hydraulic conductivity zone. The lower and higher zones of conductivity from the soil moisture profiles for both NATs W02 and W06 were identified and assigned initial estimates of hydraulic properties from the NAT W06 core samples.

In addition to the low- and high-conductivity silt layers, the neutron probe data indicated that a dry layer exists near the surface of NAT W06 and that two very dry layers were present at 4-ft and 7$\mathrm{ft}$ depths in NAT W02. The dry layers suggest that sand is present at these locations. Hydraulic properties of SDA interbed core sample taken from a 31-ft depth and described as "silty sand" in McElroy and Hubbell (1990) were assigned to the dry layer at the surface of W06, and hydraulic properties corresponding to a sample described as "sand" from a 234-ft depth core sample were assigned to the two sandy layers in NAT W02.

Finally, computational grids were assigned to the simulation profiles using exponentially decreasing and increasing spacing moving towards and away from soil type boundaries, respectively. Exponential spacing at material interfaces places more nodes in areas where they are needed (i.e., at high-gradient areas at the surface due to evaporation or infiltration and high-gradient areas across interfaces due to different material types). The end result is to reduce pressure gradients across adjacent nodes and provide a more accurate solution. The W02 model profile includes seven main soil layers and 12 transition layers and uses a total of 183 nodes. The W06 profile consists of five main soil layers and seven transition layers and uses a total of 123 nodes. The extent of layering and the depth of each layer was adjusted in the calibration process. Final simulation soil profiles are presented in Figure 2 to illustrate the model layering. 


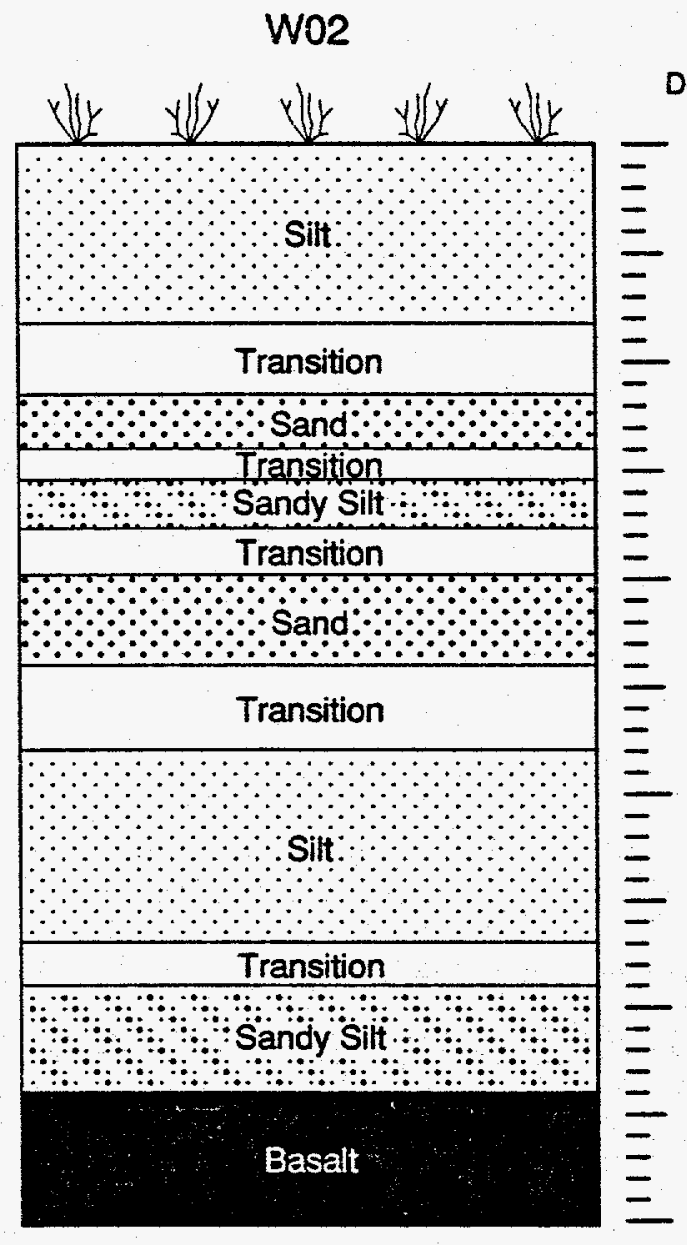

W06

Depth (cm)

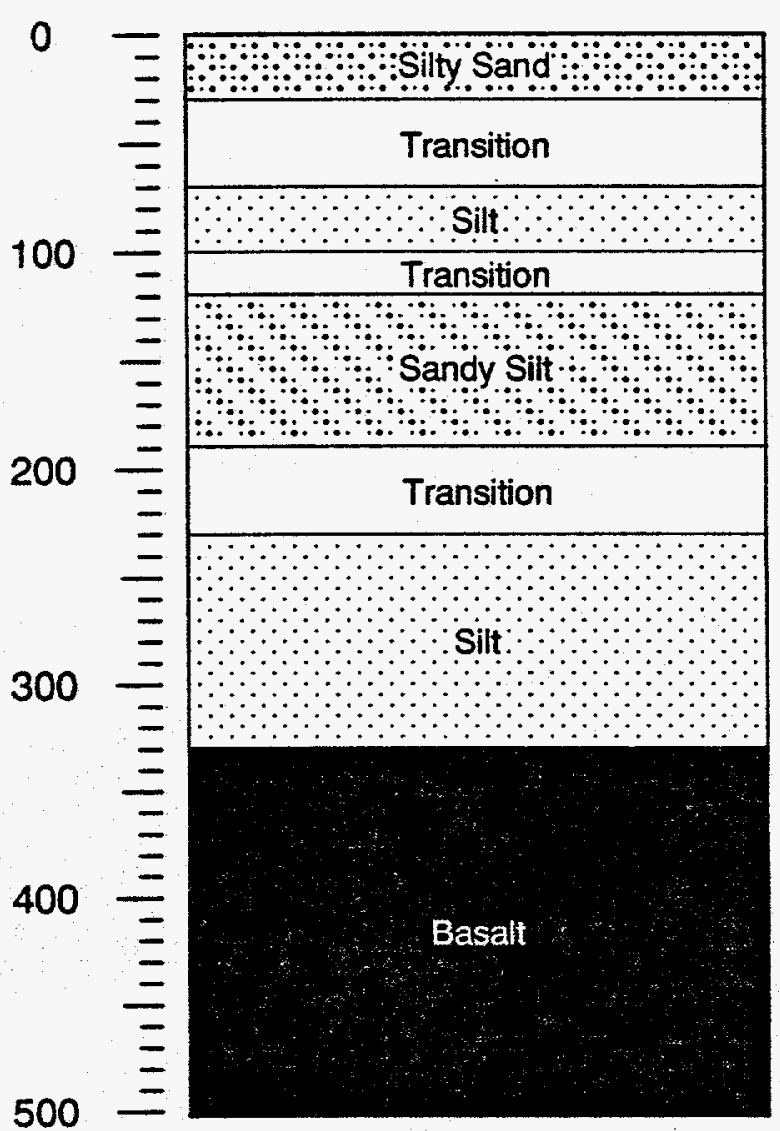

Figure 2. Simulation soil profiles for NATs W02 and W06.

\subsubsection{Initial Conditions}

Moisture movement within the surficial sediments is dynamic because the driving forces of precipitation and evapotranspiration continually change. There is rarely, if ever, a time when a uniform moisture content can be considered to be representative. The method used in this modeling study to obtain initial conditions is to select a time far enough in advance of any measurements so that the water profile in the surficial sediments is in equilibrium with the meteorologic and evapotranspirative conditions that have occurred prior to that time. The starting time that was chosen for this purpose was January 1,1985 . Since there were no field measurements of moisture content and matrix potential until near the end of 1986, this starting time allowed more than a full year as a buffer for this equilibrium to occur. Further improvement of the initial conditions was obtained by repetitively simulating one representative year of meteorological conditions until the soil moisture 
tension profile was the same at the end of each repetitive year. The 1986 meteorological conditions were arbitrarily used for this repetitive simulation to obtain the initial conditions for January 1,1985 .

\subsubsection{Boundary Conditions}

The lower boundary condition was specified as a unit gradient (water movement across the bottom boundary layer is only influenced by gravity). The upper boundary, as implemented in the UNSAT-H code, can be either a flux or constant head depending on conditions at the soil surface. Initially, during periods of infiltration or evaporation, the boundary is a flux. However, if the surface node becomes less than a minimum suction head (saturated conditions) during infiltration, or if the surface node rises above a maximum value (unnaturally dry conditions) during evaporation, the upper boundary becomes a constant head until conditions revert to normal.

When the upper boundary condition is a flux, the flux amount is a function of meteorologic conditions. If the plant option is selected in the code, transpiration amounts are distributed throughout the near surface by a rooting depth function. Simulations were tried using the plant option with various rooting depth functions. However, as will be seen in Section 5, better results were obtained by modeling evapotranspiration simply as evaporation.

As discussed in the previous section, the UNSAT-H code requires daily records of meteorologic data in order to compute the upper boundary condition. These parameters are maximum and minimum air temperature, dewpoint temperature, solar radiation, average wind speed, average cloud cover, and daily precipitation. However, the cloud cover information is used only to calculate radiative heat losses at the soil surface when the heat transfer option has been selected.

An engineered barrier simulation study by Magnuson (1993) provided a representative meteorologic data base for the period from January 1981 through December 1990 . This data base was extended through August 1993 using data collected by the National Oceanographic and Atmospheric Administration (NOAA) weather station located at CFA. Solar radiation and cloud cover information were not available from CFA. The missing solar radiation data were synthetically generated using the WGEN computer program (Richardson and Wright, 1984). WGEN allows the synthetic data to be conditioned on observed precipitation. Magnuson (1993) showed a high correlation between synthetic values generated with WGEN and measured values at a United States Geological Survey weather station adjacent to the SDA. The missing cloud cover information was not necessary because the UNSAT-H heat transfer option was not used.

Because the daily precipitation records collected at the NOAA weather station included all forms of precipitation including both rain and snow, the precipitation amounts were modified during the winter months to account for accumulation and melting of snow following the method outlined in Magnuson (1993). The results of this modification were to concentrate winter precipitation into a short period of snowmelt during the early spring.

When the ground surface is covered with snow, the snow prevents most evaporation from occurring by insulating the ground from wind and solar radiation. Additionally; as the ground freezes, the effective porosity and hydraulic conductivity can be reduced by any remaining moisture freezing in the soil pores. This reduces evaporation by limiting the amount of soil water that can move toward the soil surface. Finally, most vegetation becomes dormant during the winter months, further 
decreasing evapotranspiration. The combination of the above processes effectively stops most evapotranspiration during the winter season. To accurately simulate winter soil processes, the potential evapotranspiration was set to zero during the winter period.

\subsubsection{Model Calibration}

Model calibration is the trial and error process of adjusting input data until computed data match the field observations. This calibration included adjusting parameters from the soil hydraulic parameters, the soil layering, and timing and amount of spring snowmelt. The initial estimates of soil layering and hydraulic parameters discussed in Sections 4.2.1 and 4.2.2 were adjusted until a reasonable match between field measurements of moisture contents were obtained for NAT W02 and both moisture contents and matric potentials for NAT W06. The initial estimate of spring snowmelt was simply the amount of precipitation that occurred each winter.

A buffer year (1985) was included at the start of the simulation in which the results were not used for calibration of the model parameters. The goal of the calibration process was to match moisture contents throughout the entire simulation period; however, most emphasis was placed on matching the 1993 field data because of much more frequent monitoring during the spring infiltration.

The field monitoring of moisture contents in NATs W02 and W06 during the 1993 spring snowmelt showed that approximately $24 \mathrm{~cm}$ of water moved into the soil over a 15-day period near NAT W02, and approximately $56 \mathrm{~cm}$ of water moved into the soil near NAT W06 over a 10-day period. Both these values are far greater than the $12.2 \mathrm{~cm}$ of precipitation that occurred at CFA during the 1992-1993 winter as indicated by McElroy (1993).

Since the main objective of this study was to match the observed moisture contents in the NATs, it was necessary to increase the amount of spring snowmelt to agree with the observed infiltration. To calculate the additional snowmelt needed to match the observed infiltration, it was necessary to (a) define the winter period for each year of the simulation, (b) sum the total precipitation during this period, and (c) determine a multiplying factor to increase the amount of frozen precipitation to account for the increased infiltration from drifting or snow berms as a result of road plowing.

The criteria for selecting the start of the winter period was the beginning of the first extended period in which the average temperature fell below freezing where the average temperature was the average of the maximum and minimum values. Conversely, the criteria for selecting the last day of the winter period was the day preceding the first period in which the average temperature was above freezing. Table 3 presents the last and first days of the winter period for each calendar year of the simulation. 
Table 3. Winter period by calendar year.

\begin{tabular}{lcc}
\hline Year & Last day & First day \\
\hline 1985 & 90 & 311 \\
1986 & 46 & 322 \\
1987 & 60 & 319 \\
1988 & 56 & 312 \\
1989 & 75 & 329 \\
1990 & 60 & 330 \\
1991 & 44 & 300 \\
1992 & 40 & 297 \\
1993 & 83 & - \\
\hline
\end{tabular}

The total precipitation that occurred during the winter was summed for each year to provide a base snow accumulation. The 1993 total was compared to spring infiltration measured by McElroy (1993) to determine a maximum snow accumulation multiplication factor for NATs W02 and W06. Finally, the additional snow accumulation was distributed over a 15-day melting period for NAT W02 and over a 10-day melting period for NAT W06 in accordance with the snowmelt period described by McElroy (1993). Various multiplication factors were tried as part of the calibration process. Table 4 presents the base snow accumulation, the total precipitation during the winter period, and modified accumulations for NATs W02 and W06 for each year. The multiplication factors used in Table 4 are the final estimates and represent the drifted snow at NAT W02 and the snow berm at NAT W06.

The large amount of water that infiltrated near NAT W06 is plausible considering the NAT's location. The NAT is located in a shallow ditch next to a maintenance road. During the winter, the road is regularly plowed, which resulted in a 5 -ft snow berm slightly uphill from the NAT during 1993. In addition, snowpack measurements taken by McElroy (1993) indicated that approximately eight inches of water equivalent snowpack accumulated near NATs W02 and W06 during the winter of 1993. This value is almost two times the precipitation at CFA during the same period, indicating the importance of drifting snow in water balance simulations at the SDA.

Appendix A contains the modified meteorological data base for the simulation period along with the dates over which the additional water was applied to match field infiltration amounts. 
Table 4. Base and modified snowpack water equivalent.

\begin{tabular}{cccc}
\hline Winter period & $\begin{array}{c}\text { Base CFA precipitation } \\
\text { (in.) }\end{array}$ & $\begin{array}{c}\text { NAT W02 } \times 2.16 \\
\text { (in.) }\end{array}$ & $\begin{array}{c}\text { NAT W06 } \times 5.12 \\
\text { (in.) }\end{array}$ \\
\hline $1984-85$ & 3.28 & 7.23 & 17.14 \\
$1985-86$ & 2.36 & 5.10 & 12.07 \\
$1986-87$ & 1.08 & 2.33 & 5.52 \\
$1987-88$ & 0.94 & 2.03 & 4.81 \\
$1988-89$ & 3.51 & 7.58 & 17.96 \\
$1989-90$ & 1.69 & 3.65 & 8.65 \\
$1990-91$ & 0.41 & 0.89 & 2.10 \\
$1991-92$ & 0.96 & 2.07 & 4.91 \\
$1992-93$ & 4.30 & 9.30 & 22.00 \\
\hline
\end{tabular}




\section{MODELING RESULTS}

Distinct layering was identified in both the W02 and W06 profiles, indicating that undisturbed soil is present at both locations. However, because NAT W06 is located in a shallow ditch next to a maintenance road, the top layers probably have been disturbed to a greater extent than NAT W02. The NAT W02 location represented a highly stratified area that included materials of vastly different properties (i.e., silt and sand). The NAT W06 location represented a less heterogenous area comprised primarily of silt. Final soil layering for the NATs are depicted in Figure 3, and final estimates of soil hydraulic properties for NATs W02 and W06 are presented in Tables 5 and 6, respectively. Finally, Appendix B contains the final UNSAT-H input decks used in the W02 and W06 simulations.

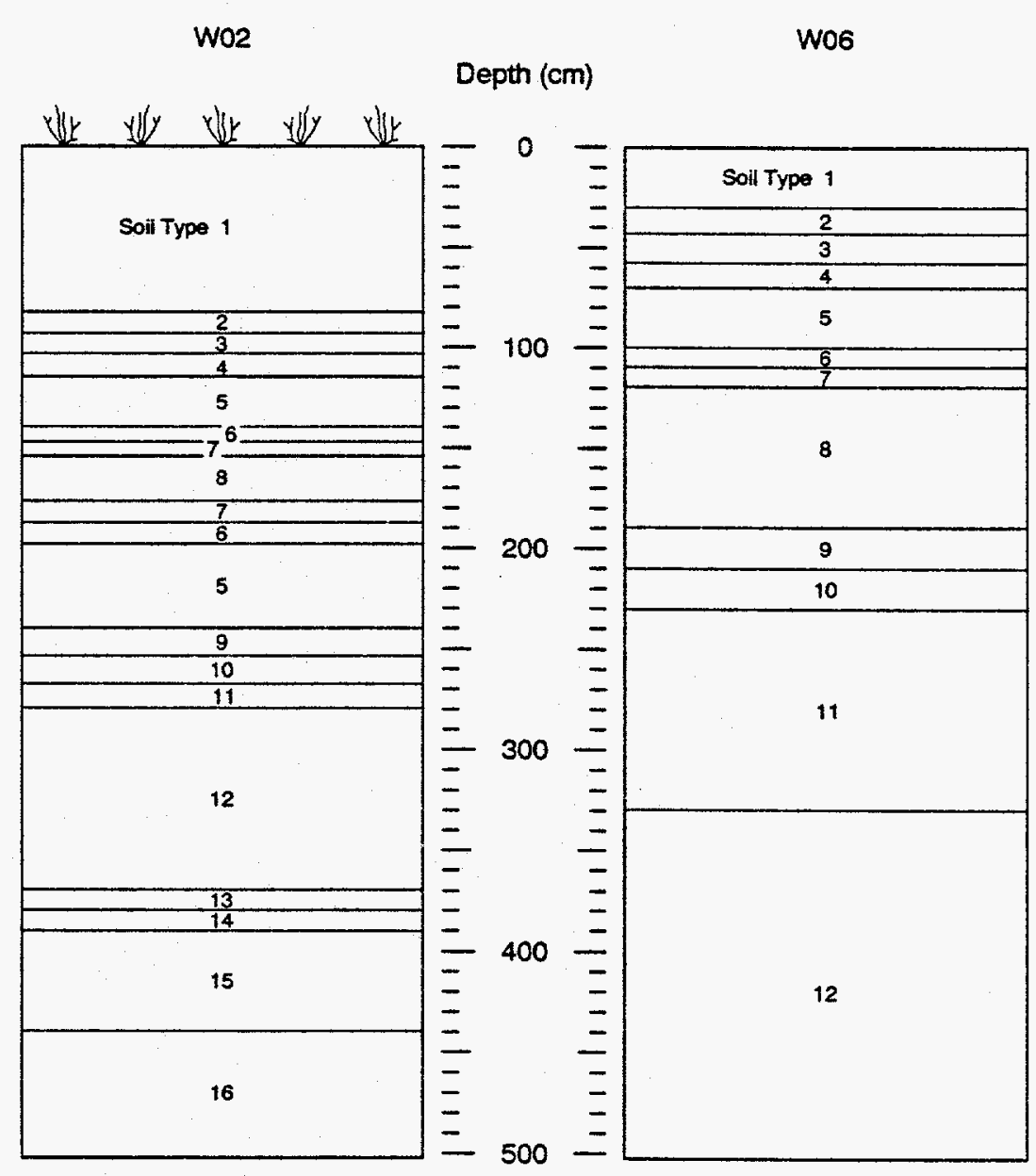

Figure 3. Soil type and layering for W02 and W06. 
Table 5. Hydraulic properties for W02.

\begin{tabular}{ccccccl}
\hline Soil layer & $\begin{array}{c}\mathrm{K}_{\mathrm{s}} \\
(\mathrm{cm} / \mathrm{hr})\end{array}$ & $\theta_{\mathrm{s}}$ & $\theta_{\mathrm{s}}$ & $\begin{array}{c}\alpha \\
(1 / \mathrm{cm})\end{array}$ & $\mathrm{n}$ & $\begin{array}{l}\text { Soil layer } \\
\text { description }\end{array}$ \\
\hline 1 & 0.9 & .500 & .060 & .0100 & 1.600 & Silt \\
2 & 6.7 & .485 & .055 & .0175 & 1.838 & Transition \\
3 & 12.5 & .470 & .049 & .0250 & 2.075 & Transition \\
4 & 18.3 & .455 & .044 & .0325 & 2.313 & Transition \\
5 & 24.1 & .440 & .038 & .0400 & 2.550 & Sand \\
6 & 16.7 & .463 & .065 & .0350 & 2.230 & Transition \\
7 & 9.3 & .487 & .093 & .0300 & 1.910 & Transition \\
8 & 1.9 & .510 & .120 & .0250 & 1.590 & Sandy silt \\
9 & 18.2 & .455 & .064 & .0309 & 2.308 & Transition \\
10 & 12.4 & .470 & .089 & .0218 & 2.065 & Transition \\
11 & 6.5 & .485 & .115 & .0127 & 1.823 & Transition \\
12 & 0.6 & .500 & .140 & .0036 & 1.580 & Silt \\
13 & 0.8 & .503 & .133 & .0054 & 1.583 & Transition \\
14 & 0.9 & .507 & .127 & .0072 & 1.587 & Transition \\
15 & 1.0 & .510 & .120 & .0090 & 1.590 & Sandy silt \\
16 & 1.0 & .230 & .015 & .0384 & 1.474 & Basalt \\
\hline
\end{tabular}

Table 6. Hydraulic properties for W06.

\begin{tabular}{ccccccl}
\hline Soil layer & $\begin{array}{c}\mathrm{K}_{\mathrm{s}} \\
(\mathrm{cm} / \mathrm{hr})\end{array}$ & $\theta_{\mathrm{S}}$ & $\theta_{\mathrm{r}}$ & $\begin{array}{c}\alpha \\
(1 / \mathrm{cm})\end{array}$ & $\mathrm{n}$ & $\begin{array}{l}\text { Soil layer } \\
\text { description }\end{array}$ \\
\hline 1 & 11.4 & .554 & .038 & .0155 & 1.800 & Silty sand \\
2 & 9.8 & .540 & .064 & .0147 & 1.763 & Transition \\
3 & 8.2 & .527 & .089 & .0139 & 1.725 & Transition \\
4 & 6.6 & .514 & .115 & .0131 & 1.688 & Transition \\
5 & 5.0 & .500 & .140 & .0123 & 1.650 & Silt \\
6 & 7.5 & .503 & .133 & .0169 & 1.630 & Transition \\
7 & 10.0 & .507 & .127 & .0216 & 1.610 & Transition \\
8 & 12.5 & .510 & .120 & .0262 & 1.590 & Sandy silt \\
9 & 10.0 & .507 & .127 & .0216 & 1.610 & Transition \\
10 & 7.5 & .503 & .133 & .0169 & 1.630 & Transition \\
11 & 5.0 & .500 & .140 & .0123 & 1.650 & Silt \\
12 & 1.0 & .230 & .015 & .0384 & 1.474 & Basalt \\
\hline
\end{tabular}




\subsection{Evaluation of Calibration Results}

To evaluate the match between the simulated and field moisture contents, both quantitative and qualitative judging were used. However, only qualitative judging was used to evaluate the match between matric potentials for NAT W06 because of the sparse number of data points (i.e., measurements were taken only at the 3-, 6-, and 9-ft depths). Two quantitative indicators were chosen to measure the match between field and simulated data. The first indicator was the root mean square (RMS) error, and the second was the correlation coefficient. Data pairs corresponding to 6-in. measurement intervals were compared with the quantitative indicators. To ensure that the data points compared corresponded to the same depth, a linear interpolation was used to obtain simulation moisture contents at the field measurement depths.

The RMS error provides a good estimation of the average error throughout the data set being compared and is defined by

$R M S=\frac{\sqrt{\sum_{i=1}^{k}\left(s_{i}-f_{i}\right)^{2}}}{k}$

where

$$
\begin{aligned}
& \mathrm{f}_{\mathrm{i}}=\text { field moisture content } \\
& \mathrm{s}_{\mathrm{i}}=\text { simulation moisture content } \\
& \mathrm{k}=\text { number of comparison points. }
\end{aligned}
$$

The correlation coefficient measures the degree to which there is a linear relationship between corresponding field and simulation data. It provides an estimate of how well the trends between the data sets agree (i.e., the shape of the soil moisture profile). The correlation coefficient is defined to be the quantity

$$
r=\frac{k \sum_{i=1}^{k} s_{i} f_{i}-\sum_{i=1}^{k} s_{i} \sum_{i=1}^{k} f_{i}}{\sqrt{\left[k \sum_{i=1}^{k} s_{i}^{2}-\left(\sum_{i=1}^{k} s_{i}\right)^{2}\right]\left[k \sum_{i=1}^{k} f_{i}^{2}-\left(\sum_{i=1}^{k} f_{i}\right)^{2}\right]}} .
$$

A perfect linear relationship between data sets would result in a correlation coefficient of 1 while at the other end of the scale, a correlation coefficient of 0 would indicate that the data sets are completely independent.

Finally, graphical comparisons between the field and simulation data were used as the qualitative judging criteria. Plots were made of the field data superimposed over the simulation data, and the agreement was visually evaluated. 


\subsection{NAT W02 Simulation Results}

Results from the W02 simulation illustrate the dramatic effect that natural layering in the sediments has on infiltration. The two distinct sand layers show a sharp drop in soil moisture. The sand layers behave as a natural capillary barrier as the larger pore spaces in the sand retain less moisture and have lower tensions than the surrounding silts. The very low moisture contents in the sand corresponds to a very low relative hydraulic conductivity, which tends to reduce infiltration and redistribution into the sand until the overlying silt layers become nearly saturated.

\subsubsection{Comparison of Field and Simulation Results}

A graphical comparison of field and simulation moisture contents is presented in Figures 4 and 5 and clearly illustrates the drying effect of the sand layers. Soil moisture profiles for representative days during winter, spring, summer, and fall seasons from 1987 to 1990 are presented for the simulation period along with soil moisture profiles before, during, and after the 1993 snowmelt. Simulated profiles are represented by dashed lines while field profiles are represented by the solid lines. Moisture contents below the second sand layer remained relatively constant throughout the modeling period.

Static moisture contents at this depth indicate that the amount of drainage at NAT W02 will be between two extremes, which are (a) steady-state drainage due to gravity at a rate equivalent to the relative hydraulic conductivity or (b) no drainage because the upward capillary forces are in equilibrium with the downward gravitational forces. The latter extreme appears to be occurring at NAT W02 because the simulation predicted matric potential gradients to be negative unity at this depth and the infiltration amounts to be very small. Only $1.6 \mathrm{~cm}$ of water moved from the silts into basalts below NAT W02 during the simulation period while if steady-state drainage was occurring, the amount would have been approximately $45 \mathrm{~cm}$.

The overall agreement between field and simulation moisture content is good. However, there appears to be an anomaly during 1986 (results not shown) and 1987. The field moisture content measurements suggest that evapotranspiration occurred only to a depth of $30 \mathrm{~cm}$ while the model predicted a behavior similar to other years in which evapotranspiration occurred down to the first sand layer at $90 \mathrm{~cm}$. Differences between the field and simulation data may be due to recontouring of the surface near NAT W02 during 1986 and 1987, which would reduce the capacity for evaporation and plant growth.

In an attempt to get a better estimate of the 1986 initial conditions, the initialization period was extended backwards by starting the simulation in 1982. However, the extended initial conditions did not improve the match during 1986 and 1987. Nevertheless, the 1993 spring infiltration event from the snowpack melting was well captured by the simulation. Moisture content in the top soil layer rose to a maximum of approximately 0.40 on March 29,1993 , in both the simulation and field measurements.

The average RMS error for the time points illustrated in the graphical comparison (Figures 4 and 5) was 0.06. The largest RMS error was 0.08 for April 8, 1987, and the smallest error was 0.05 for July 26,1988 . The average correlation coefficient was 0.87 with the lowest being 0.72 for October 2 , 1992, and the highest being 0.94 for January 4, 1989. The overall agreement between the field and simulation moisture contents was good as indicated by the low RMS error and high correlation coefficients. 

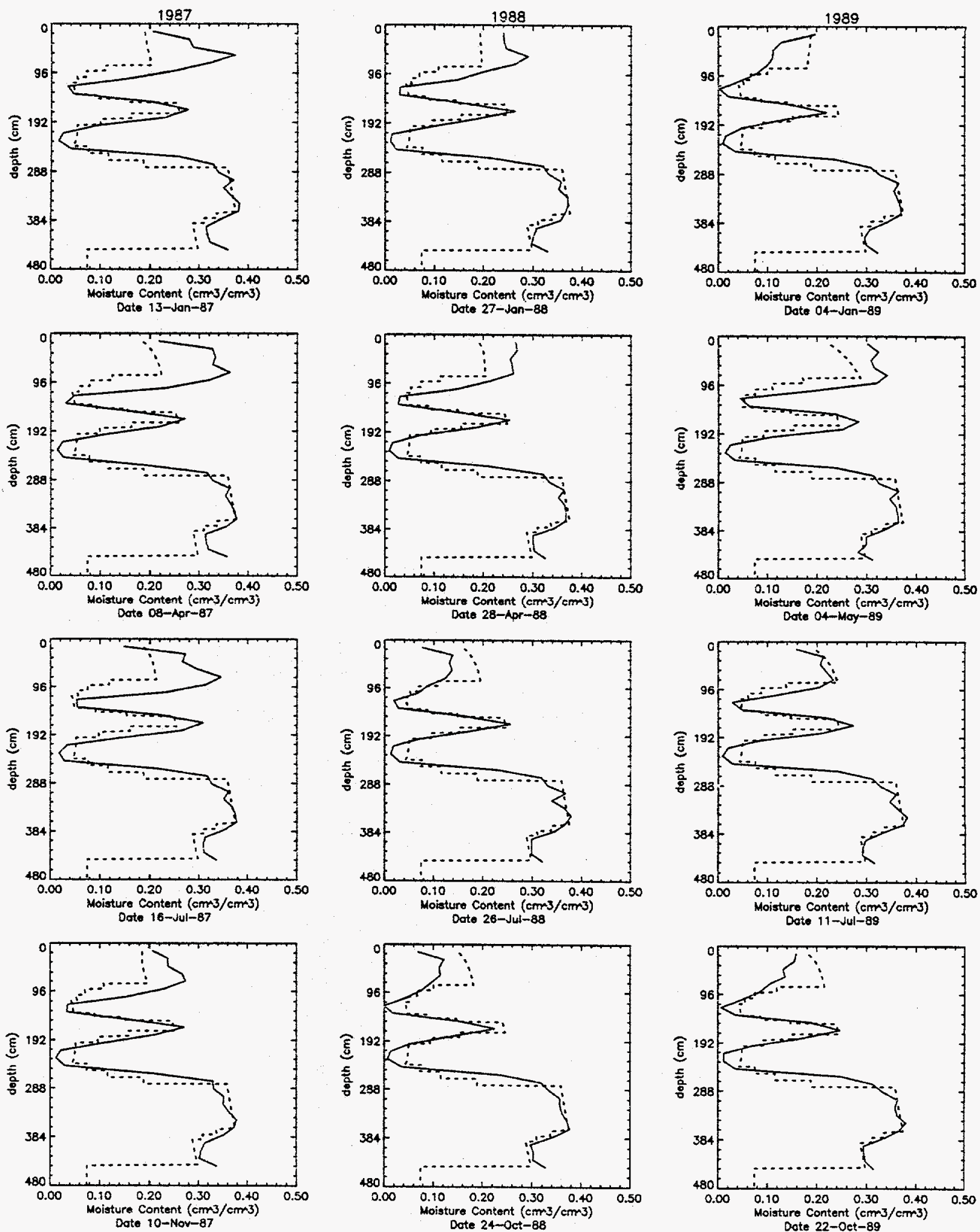

Figure 4. NAT W02 field and simulation moisture contents for 1987 to 1989 . (Simulated moisture contents are dashed lines, and field moisture contents are solid lines.) 

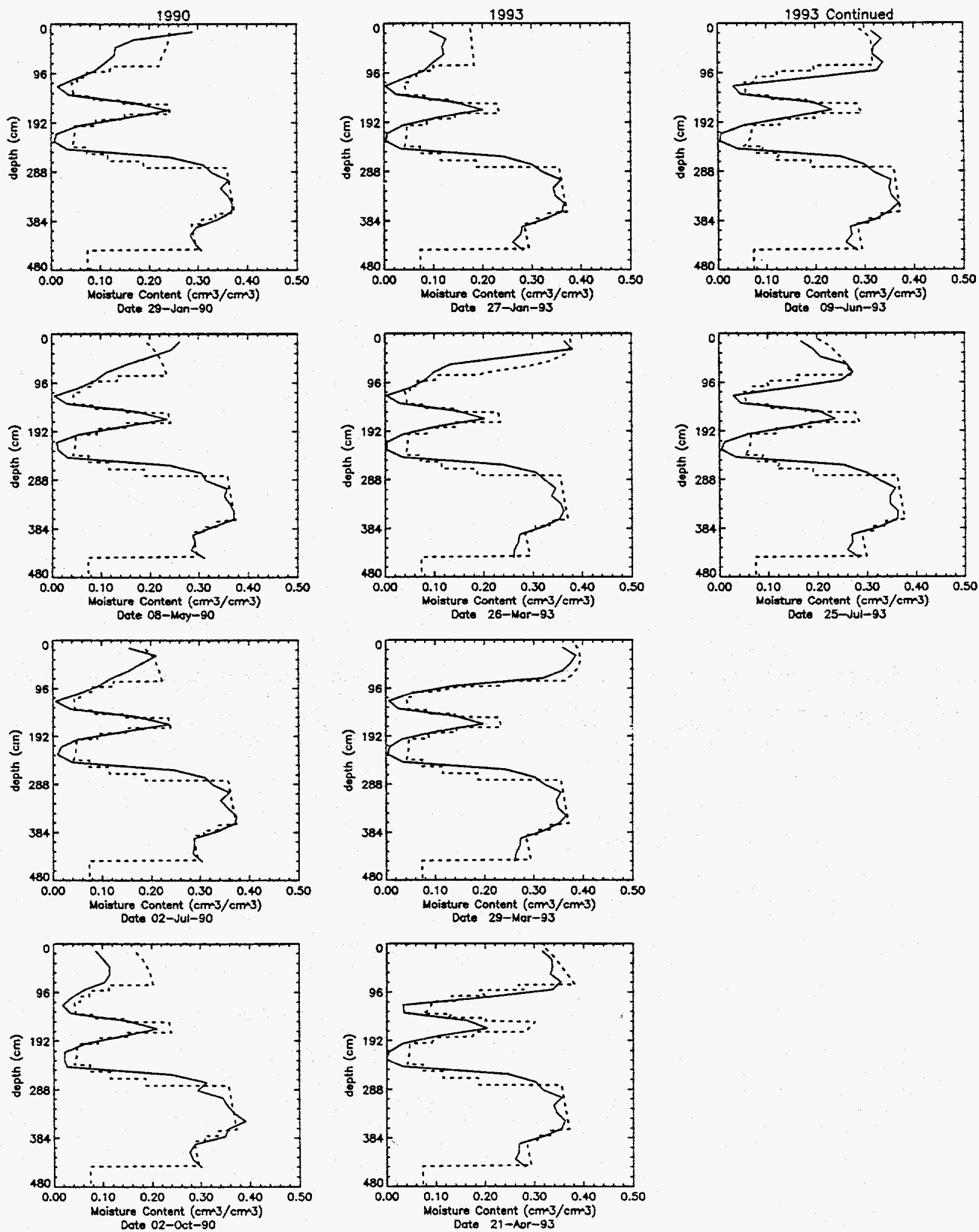

Figure 5. NAT W02 field and simulation moisture contents for 1990 to 1993 . (Simulated moisture contents are dashed lines and field moisture contents are solid lines.) 


\subsubsection{Localized Recharge}

The amount of water that infiltrated past the basalt interface is a good indication of aquifer recharge because this water has no chance of retuming to the surface via evapotranspiration. This is primarily due to the depth of the interface and the fact that the moisture retention for the basalt is much lower than the silts at the same tensions. The simulated daily drainage into the underlying basalt is illustrated in Figure 6, and yearly drainage is presented in Table 7.

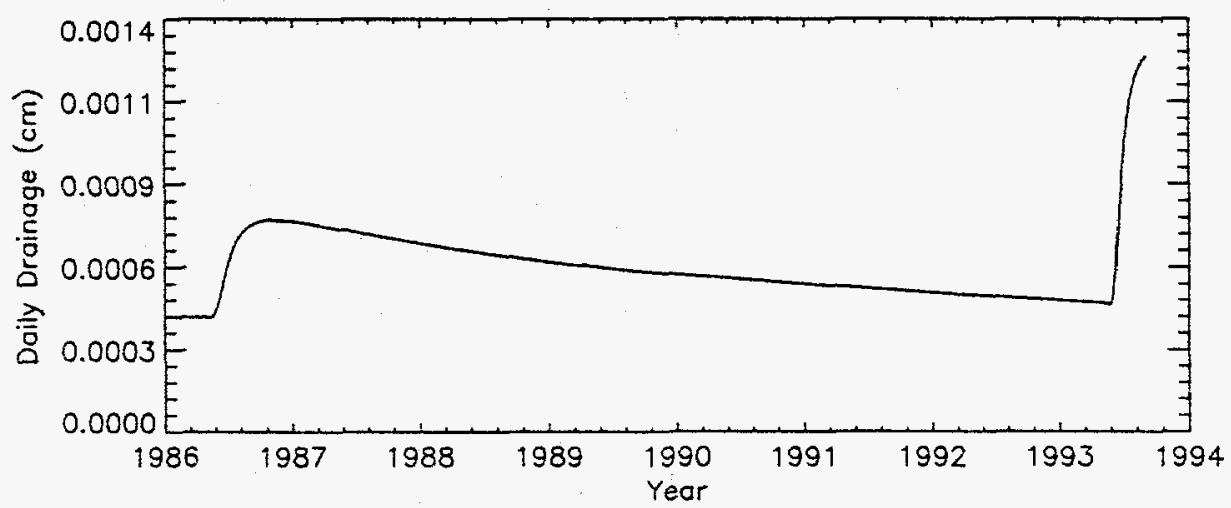

Figure 6. Daily drainage from NAT W02.

Table 7. Yearly simulation drainage from NAT W02.

\begin{tabular}{ll}
\hline Year & $\begin{array}{c}\text { Drainage } \\
(\mathrm{cm})\end{array}$ \\
\hline 1986 & 0.20 \\
1987 & 0.25 \\
1988 & 0.23 \\
1989 & 0.21 \\
1990 & 0.19 \\
1991 & 0.18 \\
1992 & 0.17 \\
1993 & $0.16^{\mathrm{a}}$
\end{tabular}

a. Drainage is for January 1 through August 31.

The simulation results indicated that a total of $1.6 \mathrm{~cm}$ of recharge occurred during the simulation period (1986 to 1993) and that $0.12 \mathrm{~cm}$ of recharge occurred from the 1993 spring snowmelt (January through July). The latter amount compared favorably to the less than $3 \mathrm{~cm}$ estimated by McElroy (1993). Two drainage peaks can be seen, one during spring 1986 and the other during spring 1993. 
The two peaks represent the two wettest years during the simulation period. The time-dependent drainage plot in Figure 6 illustrates that NAT W02 may respond to years with high precipitation amounts and not to individual spring infiltration events.

\subsubsection{Plant Transpiration}

Although the final W02 simulation did not directly include the effects of plant transpiration, the plants around NAT W02 and their effect on evapotranspiration warrants some discussion. The standard operating procedure at the SDA throughout the simulation period has been to reseed crested wheatgrass each spring in the inactive areas. Crested wheatgrass is a long-lived perennial bunchgrass that can quickly establish a stable monoculture. The area surrounding NAT W02 sustains an abundant population as observed by the authors.

A field study performed by Anderson et al. (1987) compared the ability of crested wheatgrass and other monocultures to deplete water from a clay loam soil at the INEL. The results showed that the plants extracted increasingly more water from the soil as they established deeper roots over the 3year study period. However, when plants were included in the UNSAT-H simulations, the end result was a small decrease in overall evapotranspiration. These results did not improve the agreement between the simulation, and the field measurements and were not included in this report.

The field study conducted by Anderson et al. (1987) suggested that overall evapotranspiration was increased by the presence of plants. Therefore, the exclusion of plants in the simulation may be responsible for some of the discrepancies between the observed and simulated moisture contents. Simulated moisture contents in the topmost layer were higher than those observed in the field at the end of the growing period (i.e. late summer and fall). Observed moisture contents were near 0.10, which is the lower limit of water extraction by crested wheatgrass (Anderson et al., 1987), while simulated moisture contents were 0.15 to 0.20 . In separate simulations not presented, the upper soil hydraulic parameters were changed to those of a sandy-type soil. This resulted in a better match between moisture contents during the dry summer periods, but did not match the observed spring infiltration response, and the best overall agreement was obtained using the silt-type soil.

The divergence from observed phenomenon seen in the field and that seen in the model may be due in part to the method that UNSAT-H uses to calculate transpiration. If the plant option is selected, total potential evapotranspiration is partitioned between potential transpiration and potential evaporation. The amount of transpiration that may occur is then constrained by the current growth stage of the plants. Conversely, if the plant option is not selected, the entire potential evapotranspiration becomes potential evaporation. In conclusion, the results of this particular calibration exercise suggest that the UNSAT-H code appears to simulate evapotranspiration better as evaporation than as two distinct processes (i.e., evaporation and transpiration for this particular application).

A more likely reason why the plant option did not improve the agreement between field and simulation results may be due to inadequate parameterization of crested wheatgrass transpiration. To simulate transpiration, the UNSAT-H code requires input of several parameters related to plant roots, and adequate information defining these parameters were not available for crested wheatgrass. 


\subsection{NAT W06 Simulation Results}

The behavior of NAT W06 was vastly different from NAT W02 in that water infiltrated quickly through the entire profile. The silty sand layer at the surface encouraged infiltration while it inhibited evaporation. The relatively high conductivity of sand allows surface water to quickly move through the sand layer during an infiltration event. As the potential evaporation rates increased after the event, the lower tensions in the larger sand pores restrict the movement of water back to the surface. A silt or clay soil would have more readily allowed water to be brought back to the surface.

\subsubsection{Comparison of Field and Simulation Results}

Agreements between the simulated and field moisture contents through the simulation period were very good as shown in Figures 7 and 8. Details of the 1993 snowmelt agreed closely. By March 29, 1993, both the field measurements and the simulation indicated that the bottom of NAT W06 approached saturation. However, the simulation results show that the soil profile began to dry sooner than the field data. This discrepancy may be in part due to the UNSAT-H code not being able to simulate saturated conditions. Complete agreement with the field data should have included the occurrence of perched water at the basalt interface during the spring snow melt.

Graphical comparison of simulated soil tensions and field measurements are presented in Figures 9 and 10. The illustrated dates vary slightly from those illustrated in Figures 7 and 8 due to data availability. The asterisks represent field measurements at 3,6, and $9 \mathrm{ft}$ below the soil surface, and the solid line represents simulated tensions. Overall agreement between field and simulated tensions appear to be fair. The general trends of greater tensions near the surface are seen in both the field and simulated data.

The average RMS error for the days illustrated in the graphical comparison of moisture content (Figures 7 and 8) was 0.03 . The largest RMS error was 0.09 for June 9, 1993, and the smallest error was 0.01 for November 10,1987 . The average correlation coefficient was 0.78 . The lowest was 0.2 for May 8, 1990, and the highest was 0.99 for November 10, 1987.

\subsubsection{Localized Recharge}

Most recharge occurring near NAT W06 appears to be a result of spring snowmelt. Figure 11 illustrates that three significant recharge events took place during the simulation period. These events took place in 1986, 1989, and 1993. A higher than average winter precipitation was experienced during these years with 1993 being the most dramatic year. During the spring-summer of 1993 (March 26 to July 25), the simulation predicted $36 \mathrm{~cm}$ of water passed through the basalt interface, which compares favorably to $28 \mathrm{~cm}$ of net downward drainage estimated by McElroy (1993). The time-dependent drainage shown in the lower half of Figure 11 shows a response every year and not just years with high infiltration, as did NAT W02. Total recharge over the simulation period was 87 $\mathrm{cm}$, which was primarily due to the assumption of a snow berm proportional to winter precipitation amounts adjacent to NAT W06. Table 8 presents yearly drainage from NAT W06. 

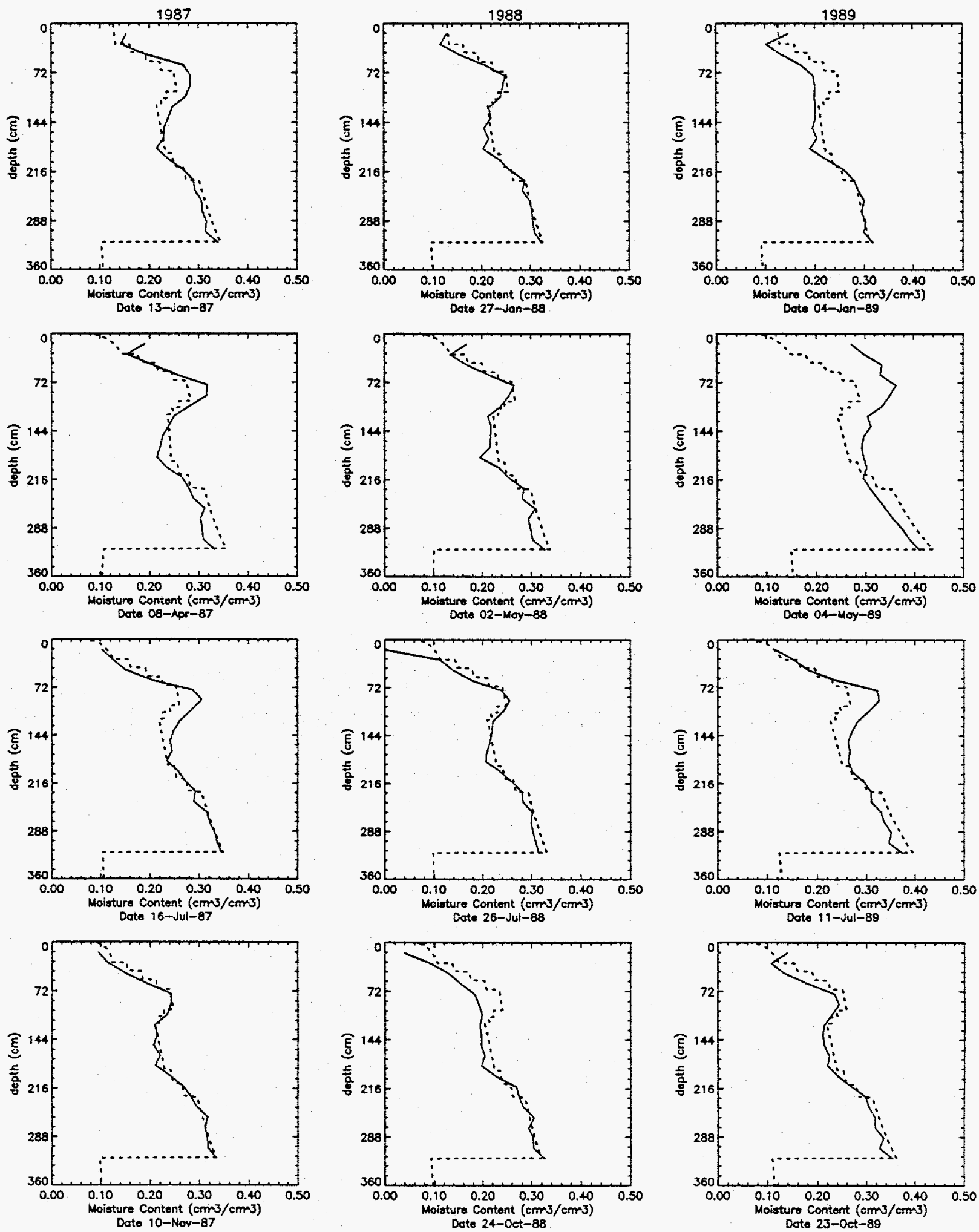

Figure 7. NAT W06 field and simulation moisture contents for 1987 to 1989. (Simulated moisture contents are dashed lines and field moisture contents are solid lines.) 

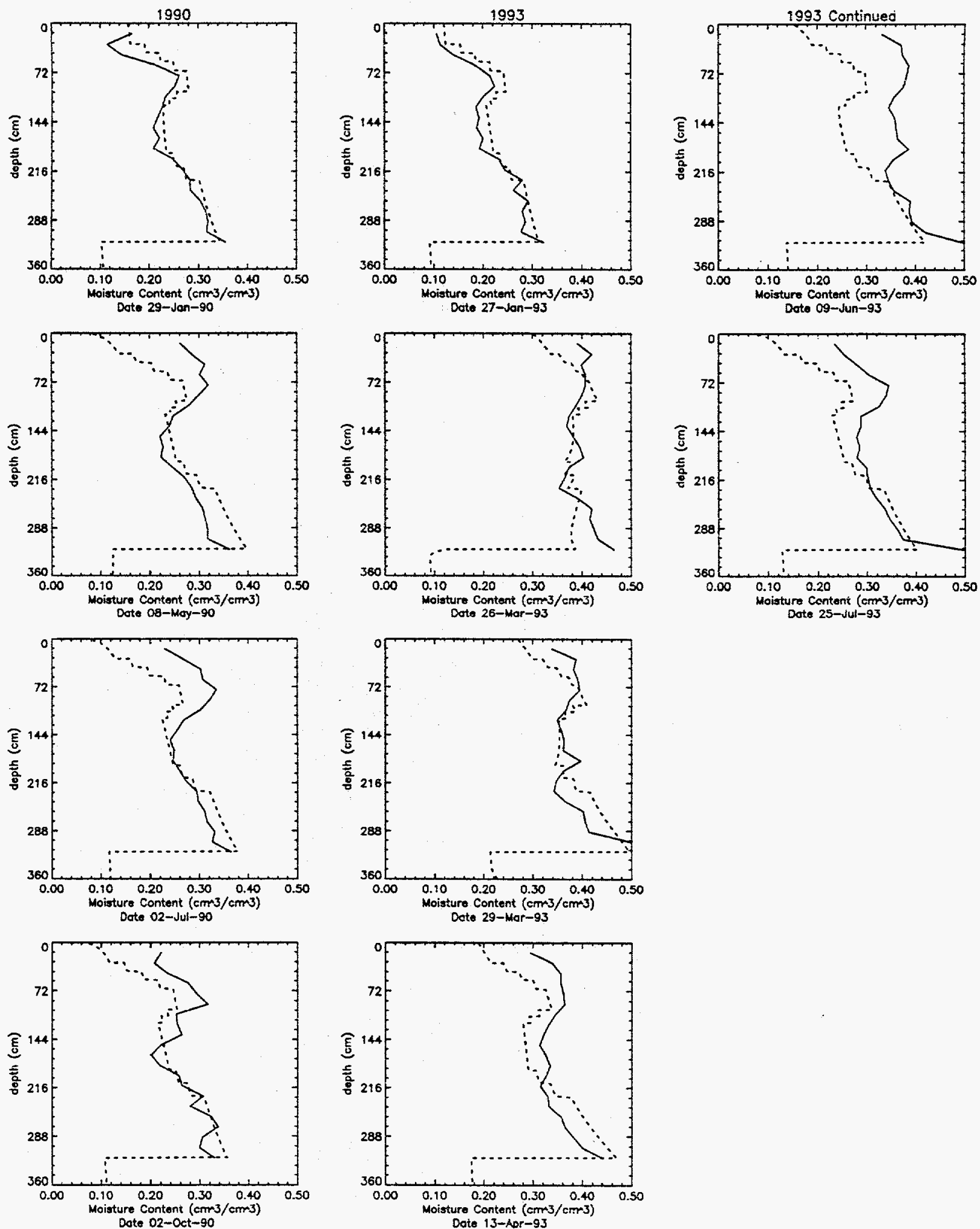

Figure 8. NAT W06 field and simulation moisture contents for 1990 to 1993 . (Simulated moisture contents are dashed lines and field moisture contents are solid lines.) 


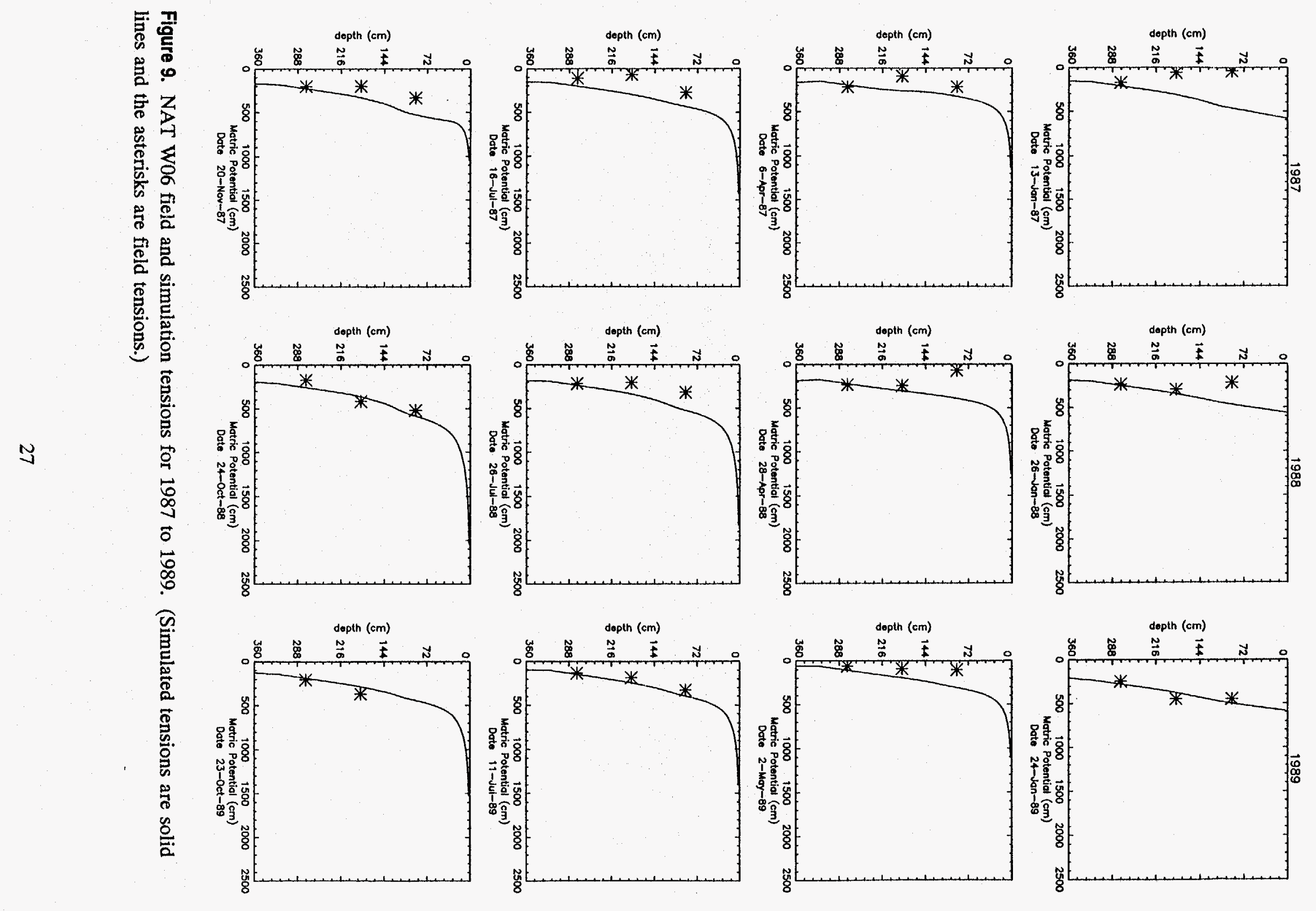



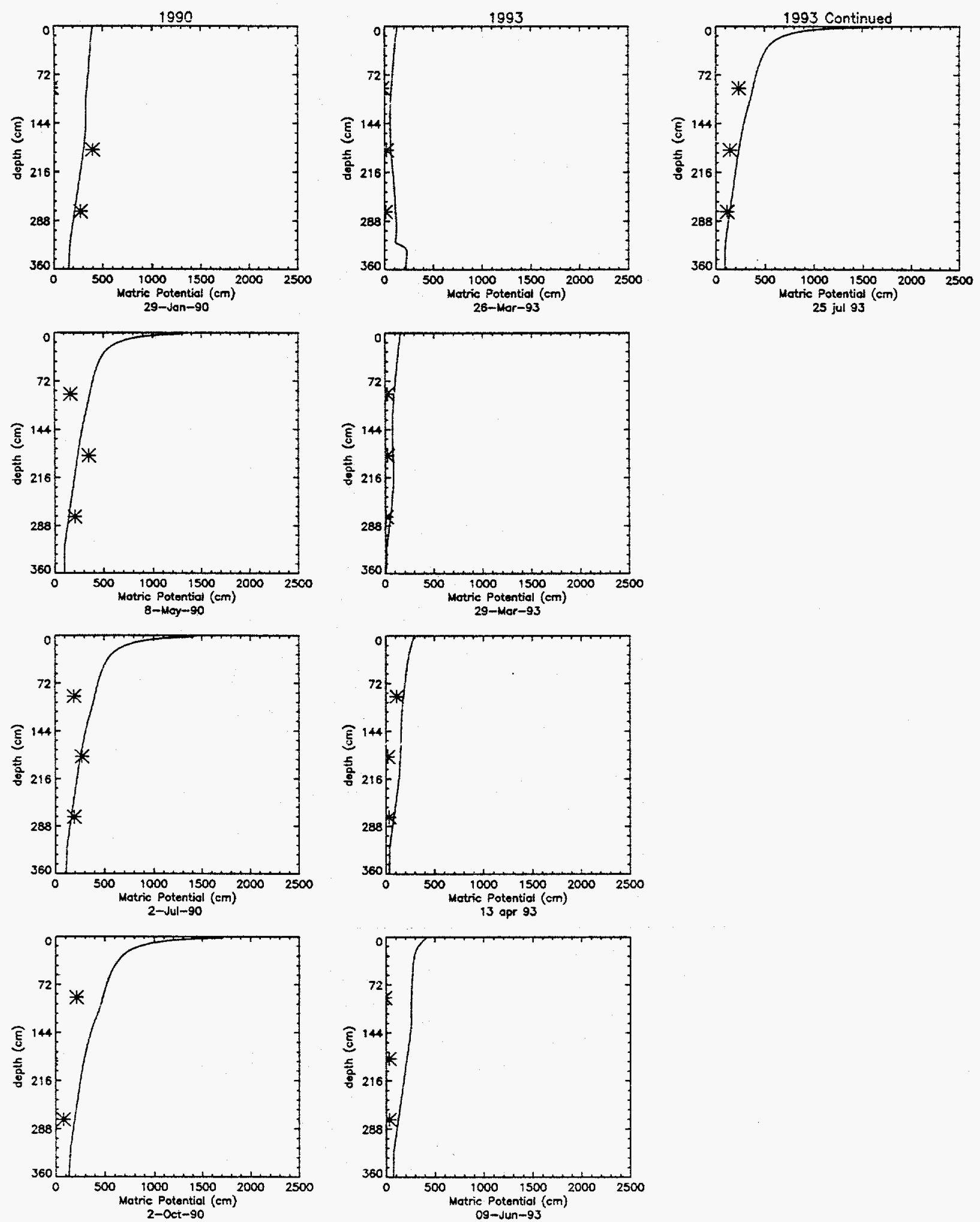

Figure 10. NAT W06 field and simulation tensions for 1990 to 1993. (Simulated tensions are solid lines and the asterisks are field tensions.) 

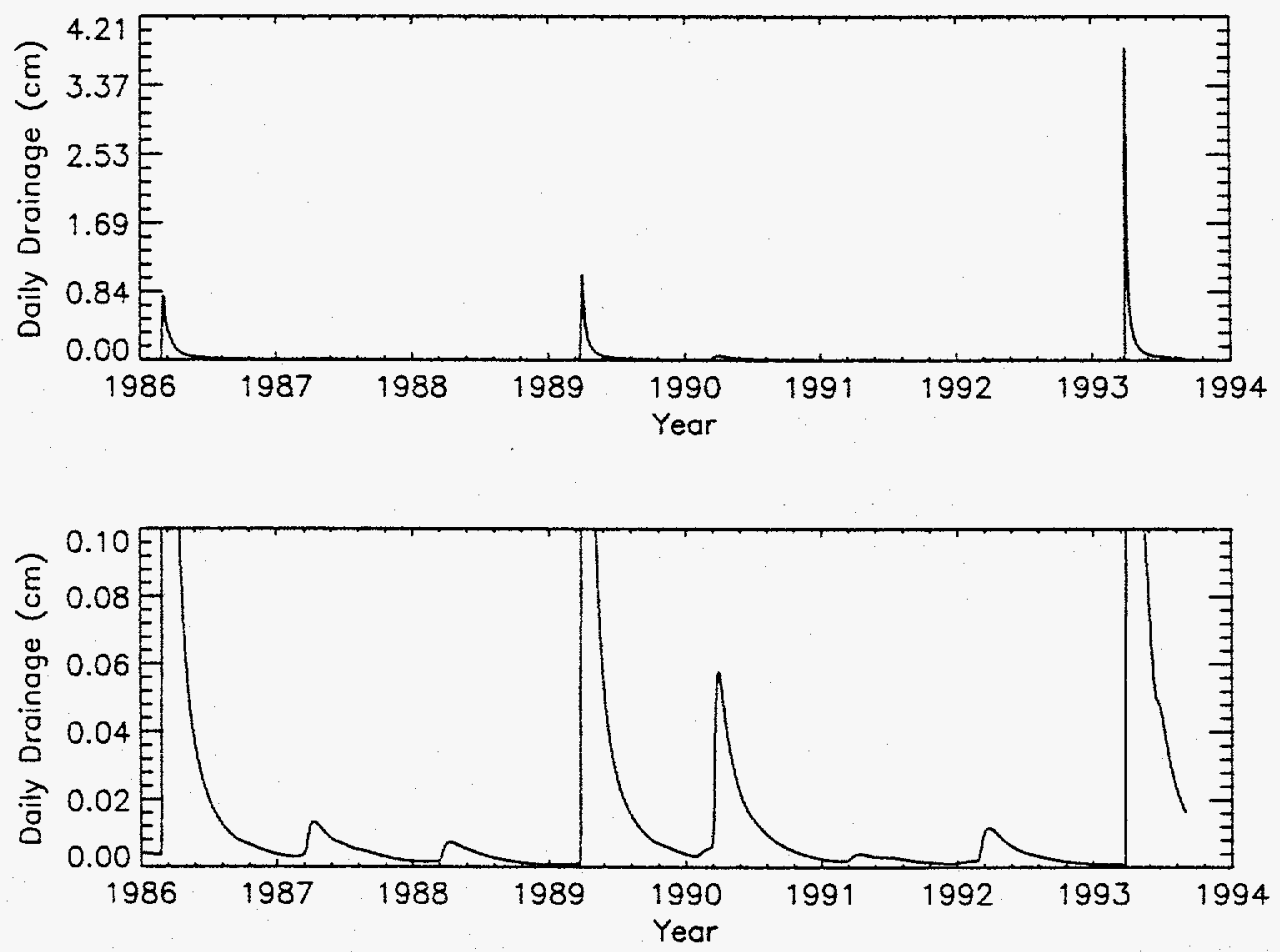

Figure 11. Drainage from NAT W06 (two different vertical scales).

Table 8. Yearly simulation drainage from NAT W06.

\begin{tabular}{cc} 
Year & $\begin{array}{c}\text { Drainage } \\
(\mathrm{cm})\end{array}$ \\
\hline 1986 & 21 \\
1987 & 2 \\
1988 & 1 \\
1989 & 20 \\
1990 & 5 \\
1991 & 1 \\
1992 & 2 \\
1993 & $36^{\mathrm{a}}$ \\
a. Drainage is for January 1 through August 31. & \\
\hline
\end{tabular}




\subsubsection{Comparison with Laboratory Scale Properties}

In 1989 , selected sediment samples from the SDA were analyzed for hydrological and physical properties (McElroy and Hubbell, 1990). The analysis included two samples taken from borehole W06, located approximately $4 \mathrm{ft}$ east of NAT W06. The samples were collected during the summer of 1986 and archived until 1989 when they were submitted for analysis. Measurements were performed for the following:

- Hydraulic conductivity

- Moisture-retention characteristics

- Moisture content

- Bulk density

- Porosity

- Particle density

- Particle-size distribution

- Unsaturated hydraulic conductivity

- Air permeability.

The majority of the testing was performed by a private laboratory. However, one of the W06 samples was analyzed by the INEL laboratory for saturated hydraulic conductivity.

The w06 samples were taken from two depth ranges. The first was taken from a core section located 52 to $82 \mathrm{~cm}$ below the surface. The second was taken from a core section located 335 to 360 $\mathrm{cm}$ below the surface. Because the samples were taken from a known general depth, the opportunity presented itself to compare the laboratory hydraulic properties with the calibrated properties from the NAT simulation. Laboratory properties are compared to the calibrated properties in Tables 9 and 10. Because the archived core sections extended through more than one layer of the simulation profile, properties are presented for depth ranges rather than specific depths.

Results of the comparison show that the calibrated hydraulic parameters agree well with the laboratory parameters. This was expected because the laboratory parameters were used as the initial estimates in the model. The calibrated parameters were within the $95 \%$ confidence limits of the laboratory parameters with the exception of $\alpha$ and $\mathrm{K}_{\mathrm{s}}$. To match the field tension measurements, it was necessary to significantly increase $\alpha$. Increasing $\alpha$ had the effect of decreasing the air entry potential and lowering the soil moisture curve. It was necessary to increase the $\mathrm{K}_{\mathrm{s}}$ values to match the travel times of the wetting front created by the spring snowmelt. The calibrated $\mathrm{K}_{\mathrm{s}}$ was an order of magnitude higher than the values determined by the private lab. However, the calibrated $\mathrm{K}_{\mathrm{s}}$ was also an order of magnitude lower than the value determined by the INEL lab.

One reason for the discrepancies between the lab estimates and the calibration estimates of hydraulic properties is that significant spatial variations may be occurring over small distances in the SDA sediments. Laboratory analysis of different samples taken from the same relatively short core sections resulted in significantly different parameter estimates for some cases. Furthermore, the depth range from which the two core sections were extracted extended through several of the simulation layers. For these reasons, the limited data from the laboratory analysis should be viewed with discretion because it may represent only a small portion of the surficial sediments. 
Table 9. Laboratory scale hydraulic properties.

\begin{tabular}{|c|c|c|c|c|c|c|c|c|c|c|c|}
\hline $\begin{array}{l}\text { Depth range } \\
(\mathrm{cm})\end{array}$ & $\begin{array}{c}\mathrm{K}_{\mathrm{s}} \\
(\mathrm{cm} / \mathrm{hr})\end{array}$ & $\begin{array}{c}\text { INEL Lab. } \\
\mathrm{K}_{\mathrm{s}}\end{array}$ & $\begin{array}{c}\alpha \\
(1 / \mathrm{cm})\end{array}$ & $\begin{array}{c}\text { Lower } \\
95 \%\end{array}$ & $\begin{array}{l}\text { Upper } \\
95 \%\end{array}$ & n & Lower & Upper & $\theta_{\mathrm{s}}$ & $\theta_{\mathrm{r}}$ & $\begin{array}{l}\text { Variation } \\
\text { (approx.) }\end{array}$ \\
\hline $52-82$ & 0.61 & 36.0 & 0.0012 & 0.0044 & 0.0195 & 1.5891 & 1.3293 & 1.8489 & 0.511 & 0.126 & 12 \\
\hline $335-360$ & 0.21 & - & 0.0071 & 0.0041 & 0.0100 & 1.5756 & 1.4017 & 1.7498 & 0.496 & 0.142 & 14 \\
\hline
\end{tabular}

Table 10. Simulation hydraulic properties.

\begin{tabular}{|c|c|c|c|c|c|c|}
\hline $\begin{array}{l}\text { Depth range } \\
(\mathrm{cm})\end{array}$ & $\begin{array}{c}\mathrm{K}_{\mathrm{s}} \\
(\mathrm{cm} / \mathrm{hr})\end{array}$ & $\begin{array}{c}\alpha \\
(1 / \mathrm{cm})\end{array}$ & $\mathrm{n}$ & $\theta_{\mathrm{s}}$ & $\theta_{\mathrm{r}}$ & $\begin{array}{l}\text { Variation } \\
\text { (approx.) }\end{array}$ \\
\hline $43-57$ & 8.20 & 0.0139 & 1.725 & 0.527 & 0.089 & 3 \\
\hline $57-70$ & 6.60 & 0.0131 & 1.687 & 0.514 & 0.115 & 4 \\
\hline $70-100$ & 5.00 & 0.0123 & 1.650 & 0.500 & 0.140 & 5 \\
\hline $230-320$ & 5.00 & 0.0123 & 1.650 & 0.500 & 0.140 & 11 \\
\hline
\end{tabular}




\subsubsection{Comparison with Field Scale Properties}

The frequent monitoring of NAT W06 during the 1993 spring snowmelt infiltration event provided sufficient data to perform field scale estimation of hydraulic properties. McElroy used the soil moisture and matric potential data during drainage periods to estimate hydraulic parameters for a characteristic curve and an unsaturated conductivity curve at different depths. Estimates for $\mathrm{K}_{s}, \theta_{s}, \theta_{r}$ and $n$ were obtained using the UNGRA computer code (van Genuchten, 1988) at 1/2-ft intervals, while estimates for $\mathrm{K}_{\mathrm{s}}, \theta_{\mathrm{s}}, \theta_{\mathrm{r}} \mathrm{n}$, and $\alpha$ at 3-ft and 6-ft depths were determined using the RETC computer code (van Genuchten, 1985). Results of the field scale investigation in Table 11 can be compared to the simulation results in Table 12 .

Resuits from the comparison indicate that the calibrated $\mathrm{K}_{\mathrm{s}}$ values in the low conductivity zones tend to be an order of magnitude higher while the high conductivity zones values are comparable. Field estimates of porosity are lower than the calibration estimates. Values of 0.40 vs. 0.50 were obtained for the calibration and field estimates, respectively. Estimates for residual moisture contents in most of the relatively high conductivity zones were zero, suggesting that the very low pressure section of the soil moisture curve determined from the field parameters may not be valid. Field estimates for $\alpha$ at the 3- and 6-ft depths were lower and higher, respectively, than the calibration estimates. Finally, field estimates for the n parameter tended to be lower than the calibration estimates, especially in the higher conductivity regions. A significant amount of variation was seen in the field estimates, which can be seen in the large spread between the $95 \%$ confidence intervals. As can be seen in Table 11, many of the intervals ranged in the negative range, which physically should not occur.

To evaluate the usefulness of the field scale estimations of hydraulic parameters, a simulation was run using these parameters. Because field estimates of hydraulic parameters were not available for the top $1 \mathrm{ft}$ of soil, the parameters were estimated from the other layers. Additionally, because $\alpha$ was evaluated only at the 3 and $6 \mathrm{ft}$ depths, intermediate values were estimated and were improved through a very limited series of calibration runs.

Figures 12 and 13 illustrate that the soil moistures predicted with the field measurements show reasonable agreement with the actual field measurements. The hydraulic conductivities of the higher moisture content zones were nearly two orders of magnitude lower than those estimated by the calibration runs. As can be seen in Figures 12 and 13, the wetting front resulting from the 1993 spring snowmelt does not appear to move as fast as the field measurements indicate. Also, during the same heavy infiltration periods, the simulation results indicated that a significant proportion of the applied water was lost to runoff due to the very low hydraulic conductivity near the surface.

The simulation results showed that simply relying on the field data for hydraulic properties may not be appropriate. Some interpretation of the field estimates is necessary when the data are input into a numerical model. Nevertheless, field estimates can provide a good initial estimate for the hydraulic properties.

b. Unpublished work, 1994. 
Table 11. Field scale hydraulic properties.

\begin{tabular}{|c|c|c|c|c|c|c|c|c|c|c|c|c|c|c|c|}
\hline $\begin{array}{l}\text { Depth } \\
(\mathrm{cm})\end{array}$ & $\begin{array}{c}\mathrm{K}_{\mathrm{s}} \\
(\mathrm{cm} / \mathrm{hr})\end{array}$ & $\begin{array}{c}\text { Lower } \\
95 \%\end{array}$ & $\begin{array}{l}\text { Upper } \\
95 \%\end{array}$ & $\theta$ & Lower & Upper & $\theta_{r}$ & Lower & Upper & $\begin{array}{c}\alpha \\
(1 / \mathrm{cm})\end{array}$ & Lower & Upper & $\mathbf{n}$ & Lower & Upper \\
\hline 30.5 & 0.81 & -4.42 & 6.04 & .441 & .316 & .566 & .000 & & & $0.0300^{3}$ & & & 1.235 & 1.040 & 1.420 \\
\hline 45.7 & 0.02 & -0.01 & 0.05 & .386 & .376 & .397 & .000 & & & $0.0055^{3}$ & & & 1.535 & .9217 & 2.148 \\
\hline 61.0 & 0.02 & -0.01 & 0.05 & .386 & .376 & .397 & .000 & & & $0.0055^{3}$ & & & 1.535 & .9217 & 2.148 \\
\hline 76.2 & 1.20 & -105 & 107. & .394 & .382 & .406 & .171 & -9.10 & 9.44 & $0.0500^{3}$ & & & 1.134 & -5.800 & 8.067 \\
\hline 91.4 & 0.15 & -0.20 & 0.51 & .382 & .376 & .388 & .000 & & & 0.0055 & -0.0009 & 0.1200 & 1.158 & 1.037 & 1.285 \\
\hline 107. & 2.66 & -27.4 & 32.7 & .391 & .304 & .477 & .000 & & & $0.0220^{3}$ & & & 1.124 & .9122 & 1.335 \\
\hline 122 & 3.26 & -37.7 & 44.2 & .376 & .262 & .491 & .000 & & & $0.0385^{3}$ & & & 1.141 & .8909 & 1.391 \\
\hline 137. & 0.06 & -0.29 & 0.41 & .364 & .302 & .425 & .221 & -.234 & .675 & $0.0551^{3}$ & & & 2.378 & -7.478 & 12.35 \\
\hline 167 & 2.42 & -13.7 & 18.5 & .403 & .309 & .496 & .000 & & & $0.0551^{3}$ & & & 1.220 & .9971 & 1.443 \\
\hline 183. & 45.5 & -208 & 299. & .524 & .335 & .711 & .000 & & & 0.1046 & -0.1462 & 0.3554 & 1.233 & 1.168 & 1.298 \\
\hline 213 & 0.04 & 0.01 & 0.07 & .347 & .259 & .319 & .283 & .259 & .319 & $0.0055^{3}$ & & & 18.73 & -132.2 & 169.6 \\
\hline 229. & 3.92 & -74.7 & 82.6 & .368 & .226 & .511 & .000 & & & $0.0055^{3}$ & & & 1.131 & .7026 & 1.559 \\
\hline 244. & 11.9 & -95.9 & 119. & .402 & .296 & .508 & .000 & & & $0.0055^{3}$ & & & 1.141 & 1.002 & 1.281 \\
\hline
\end{tabular}


Table 12. Simulation hydraulic properties.

\begin{tabular}{|c|c|c|c|c|c|c|}
\hline $\begin{array}{l}\text { Depth } \\
(\mathrm{cm})\end{array}$ & $\begin{array}{c}\mathrm{K}_{\mathrm{s}} \\
(\mathrm{cm} / \mathrm{hr})\end{array}$ & $\theta_{s}$ & $\theta_{\mathrm{t}}$ & $\begin{array}{c}\alpha \\
(1 / \mathrm{cm})\end{array}$ & n & $\begin{array}{l}\text { Soil layer } \\
\text { description }\end{array}$ \\
\hline $30-43$ & 9.8 & .540 & .064 & .0147 & 1.763 & Transition \\
\hline $43-57$ & 8.2 & .527 & .089 & .0139 & 1.725 & Transition \\
\hline $57-70$ & 6.6 & .514 & .115 & .0131 & 1.688 & Transition \\
\hline $70-100$ & 5.0 & .500 & .140 & .0123 & 1.650 & Silt \\
\hline $100-110$ & 7.5 & .503 & .133 & .0169 & 1.630 & Transition \\
\hline $110-120$ & 10.0 & .507 & .127 & .0216 & 1.610 & Transition \\
\hline $120-190$ & 12.5 & .510 & .120 & .0262 & 1.590 & Sandy Silt \\
\hline $190-210$ & 10.0 & .507 & .127 & .0216 & 1.610 & Transition \\
\hline $210-230$ & 7.5 & .503 & .133 & .0169 & 1.630 & Transition \\
\hline $230-320$ & 5.0 & .500 & .140 & .0123 & 1.650 & Silt \\
\hline
\end{tabular}



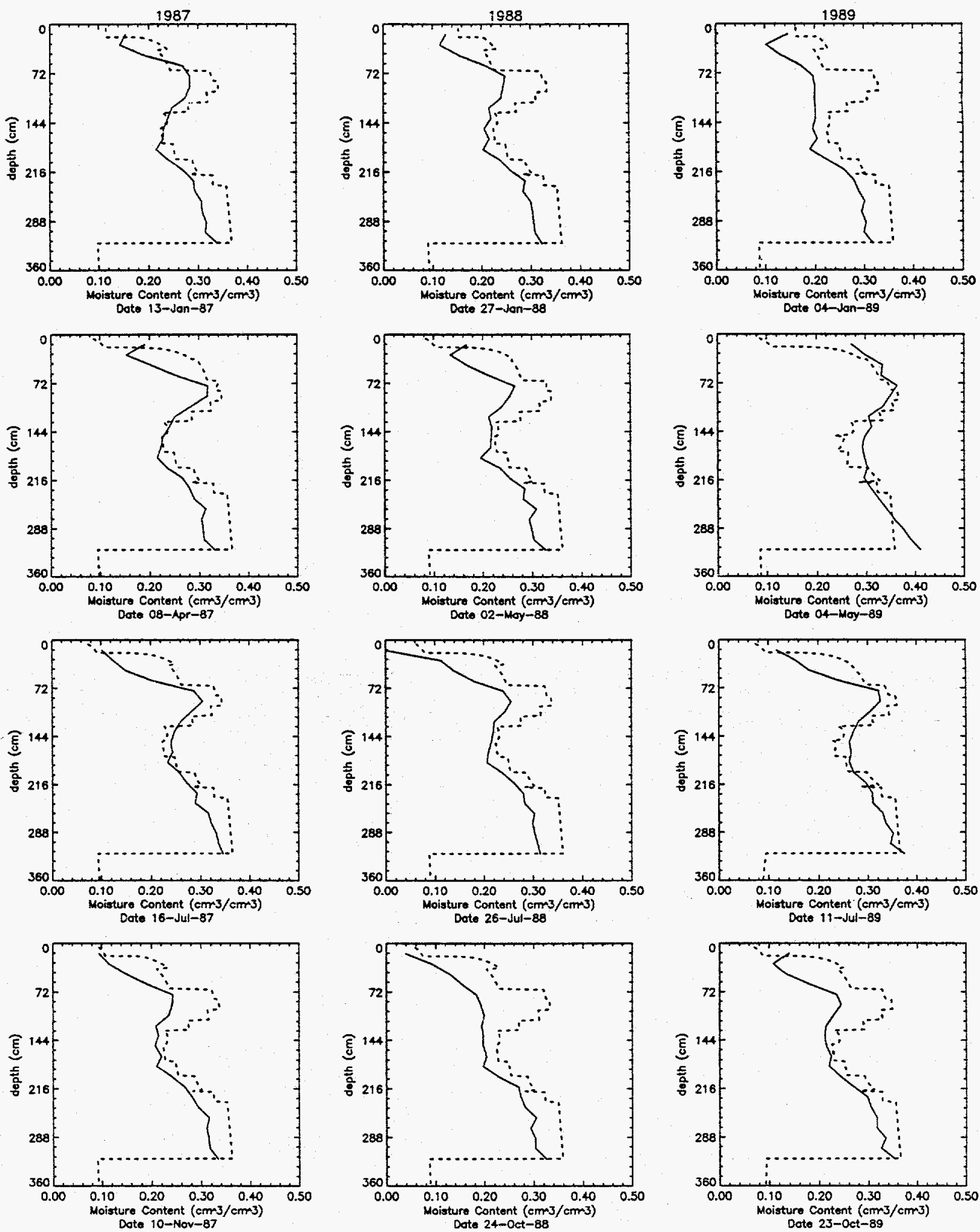

Figure 12. NAT W06 field and simulation moisture contents using field estimated parameters for 1987 to 1989. (Simulated are dashed lines and field are solid lines.) 

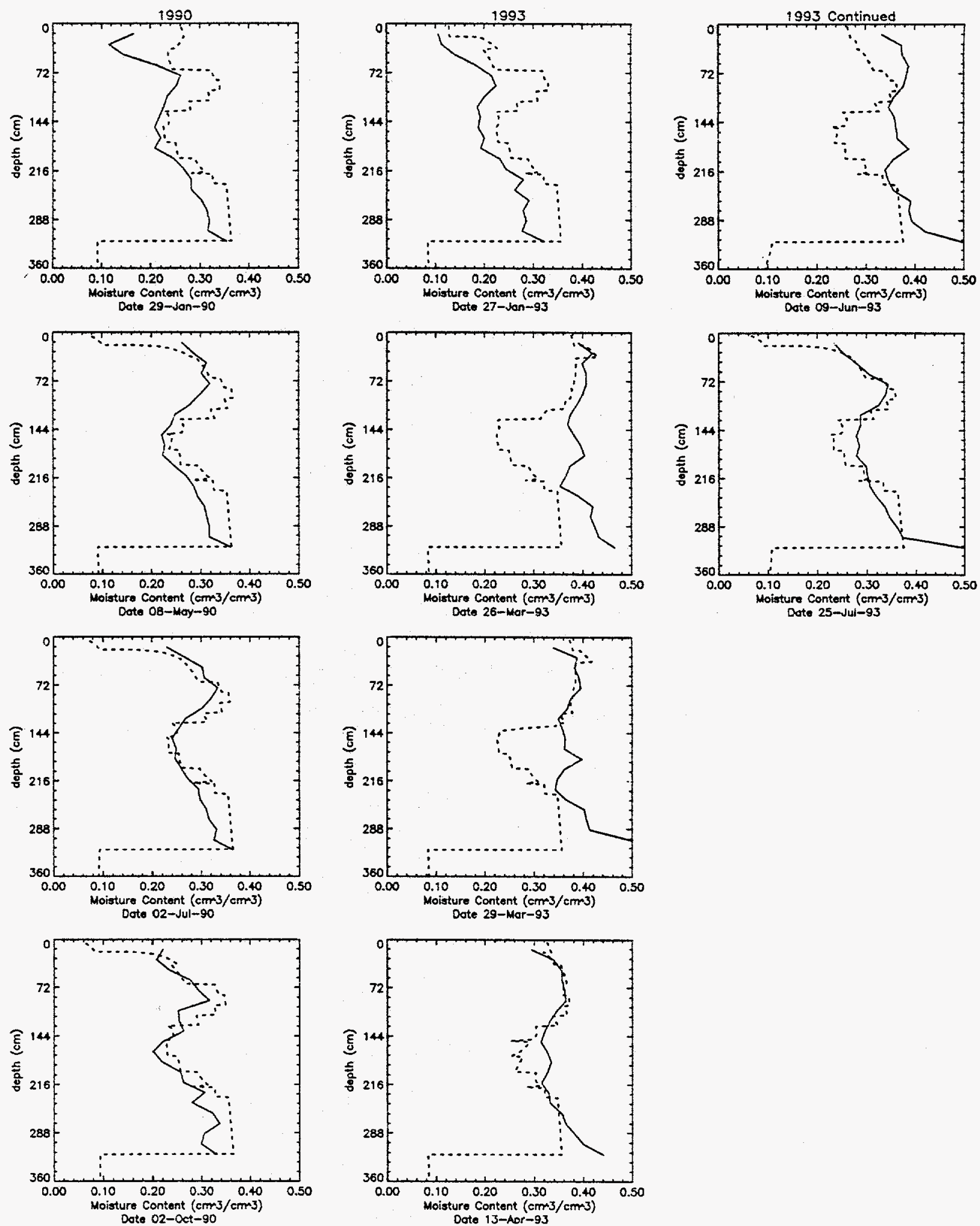

Figure 13. NAT W06 field and simulation moisture contents using field estimated parameters for 1990 and 1989. (Simulated are dashed lines and field are solid lines.) 


\subsubsection{Role of Basalt interface at NAT W06}

The simulation results provided an opportunity to quantitatively explain some of the infiltration and redistribution phenomena occurring at the SDA. One such phenomenon is the role played by the basalt interface. The basalt interface appears to behave similar to a capillary barrier, which inhibits water movement out of the overlying silts until they become nearly saturated. This behavior is primarily due to the very low relative hydraulic conductivity of basalt at the baseline tensions (the relative steady matric potential prior to water movement from snowmelt or precipitation). The basalts also retain much less water than the silts at the same tension.

This behavior can also be seen in the soil moisture curves and relative hydraulic conductivity curves. Baseline tensions at the basalt interface are near $170 \mathrm{~cm}$. Figure 14 illustrates the soil moisture curves and the relative hydraulic conductivity curves at the silt and basalt from simulation W06. Moisture contents at $170 \mathrm{~cm}$ tension are 0.10 for the basalt and 0.35 for the silts while the relative hydraulic conductivity is $0.1 \mathrm{~cm} / \mathrm{hr}$ for the silts and near zero for the basalt.
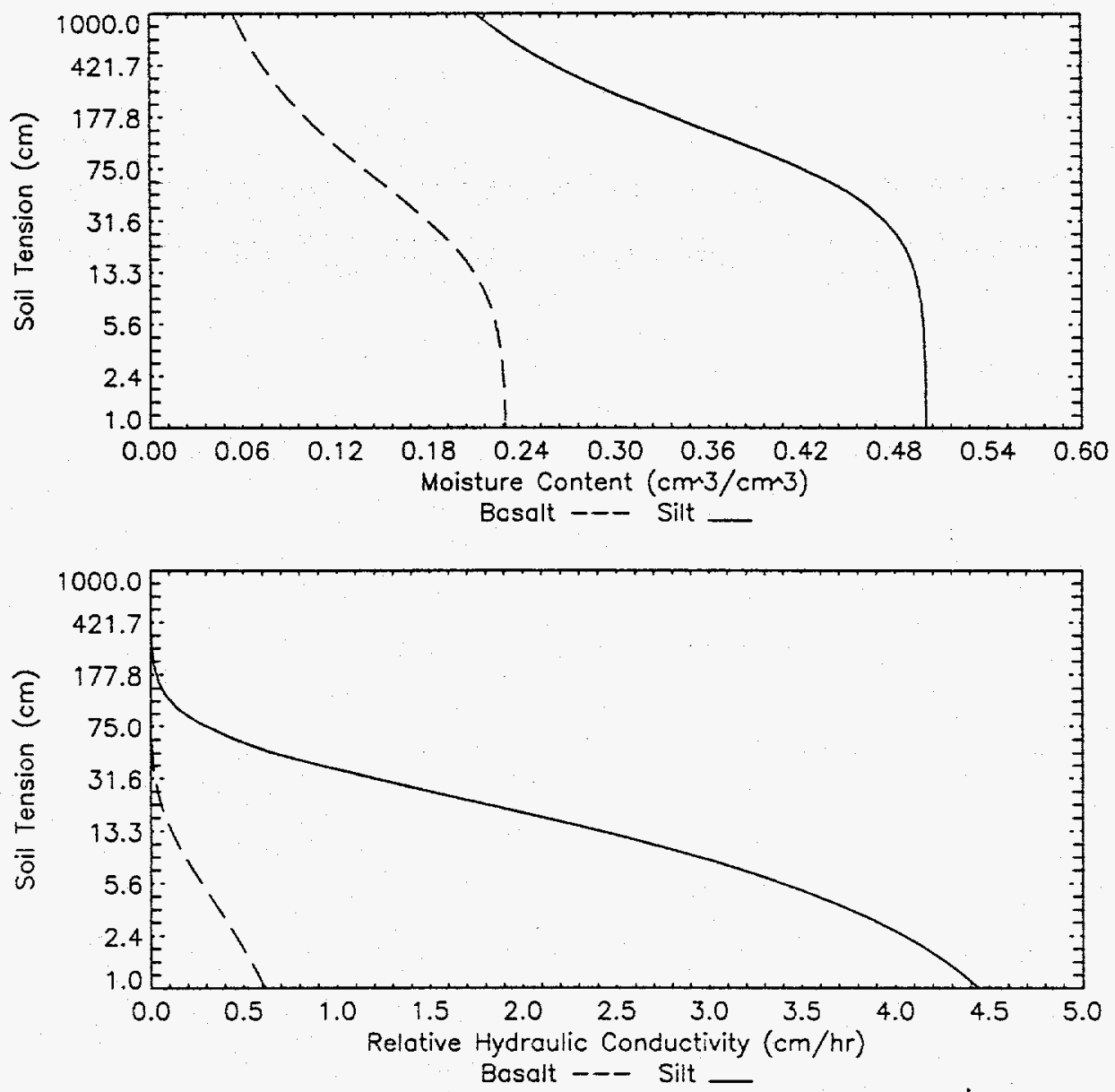

Figure 14. Comparison of basalt and sand soil moisture curves. 
The presence of perched water immediately over the basalt interface can also be explained in the constitutive relation curves. The relative hydraulic conductivity of the basalt is near zero until tensions drop to $50 \mathrm{~cm}$ while the corresponding silt moisture content is apprcaching saturation. The end resuit is that a large influx of water, such as that from the spring snowmelt, causes the silts to quickly saturate and then backs up until sufficient time has passed to allow drainage into the basalts.

This behavior can be clearly seen during the 1993 spring snowmelt at NAT W06. Drainage from the sediments remain extremely low until soil moisture approaches saturation at which time a large pulse of water enters the basalt. Figure 15 shows sediment moisture contents in the silts immediately above the basalt and daily drainage into the basalt layer.

From a modeling standpoint, the significance of the basalt interface is that a unit gradient boundary condition (free drainage due to gravity) is not appropriate at the bottom of the silts, and infiltration modeling at the SDA should include the underlying basalts.

Finally, it should be noted that this simulation study consisted of a 1-dimensional model that assumed a sharp interface between the silt and basalt. The effects of fracturing or 2-dimensional effects due to the uneven nature of the basalt surface were not considered. Because most of the nearsurface fractures are likely to be infilled with silt, the actual behavior of the basait interface may be similar but is probably spread out over a small distance.
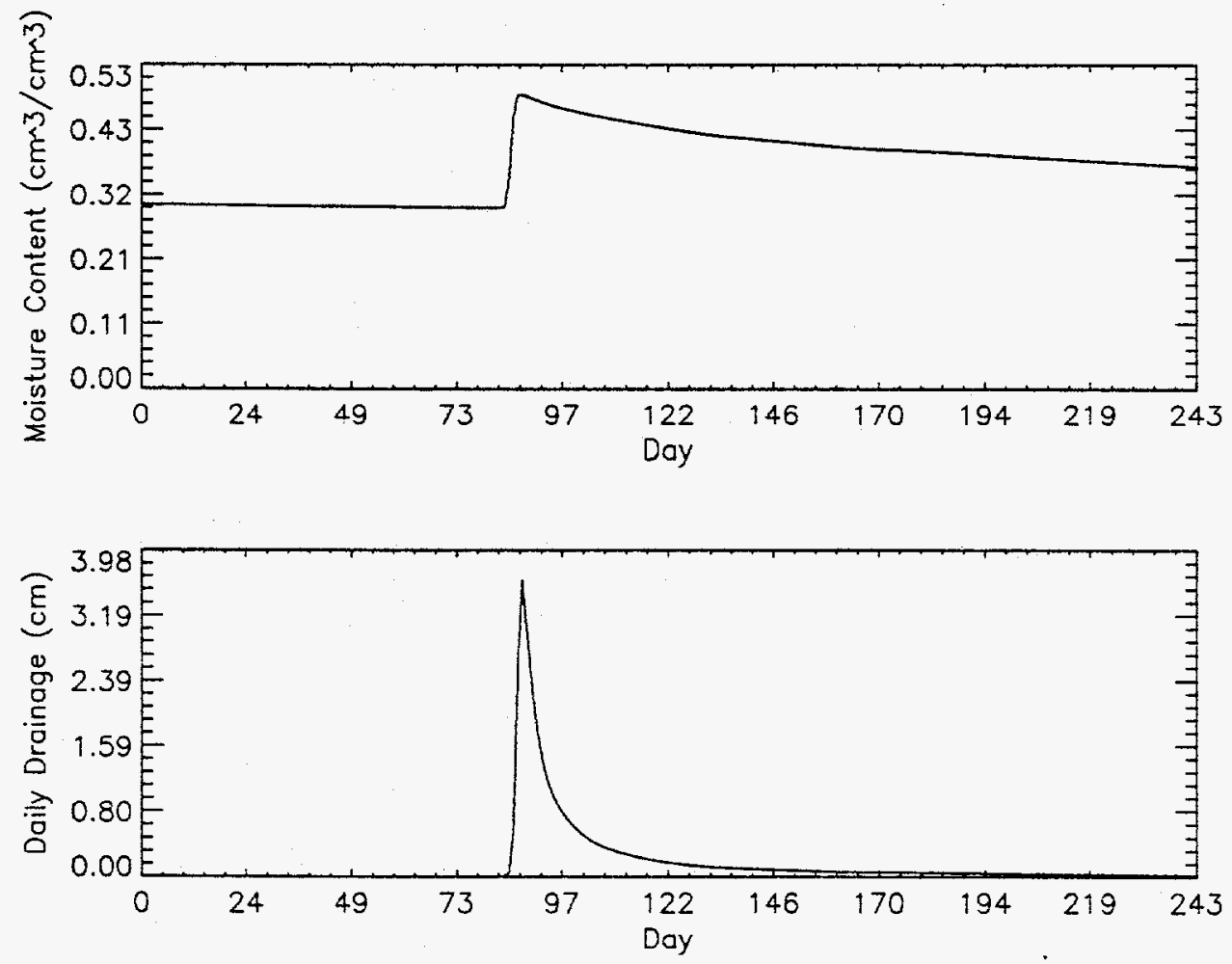

Figure 15. Sediment moisture contents and daily drainage during 1993. 


\section{CONCLUSIONS AND FUTURE DIRECTIONS}

A calibrated simulation study of moisture infiltration at two locations within the INEL SDA was conducted for the purpose of obtaining insight into the amount and timing of infiltration occurring at the SDA. The main focus of this simulation was on obtaining a good match between field and simulated data. In the process of performing the calibration exercise and obtaining this match, insight was gained as to the nature of infiltration at the SDA, which allowed the following conclusions and recommendations to be drawn.

\subsection{Conclusions}

The infiltration occurring at the SDA appears to be highly localized as the amounts and timing can vary dramatically at different locations. The net infiltration at the two locations was vastly different, with the W02 simulation predicting only $2.4 \mathrm{~cm}$ of net infiltration occurring during the 1986 through 1993 simulation period. During the same period, nearly $87.0 \mathrm{~cm}$ of water moved down at the W06 location.

The underlying fractured basalt appears to behave similar to a capillary barrier. This behavior inhibits moisture movement into the underlying basalts until moisture contents in the silts approach saturation. Furthermore, a unit gradient assumption in the silts is not appropriate because the basalts have a much lower relative hydraulic conductivity than the silts at the same tension. As a result, a large proportion of recharge occurring at the SDA is due to spring snowmelt, and only a relatively small amount of recharge occurs otherwise.

Snowpack water equivalents can be greater than cumulative winter precipitation due to the accumulation of drifting snow within the SDA. The field data collected by McElroy (1993) indicate that snowpack water equivalent was up to twice the cumulative winter precipitation at CFA. The simulation results reinforced this conclusion because adjusting the timing and increasing the amount of spring infiltration from snowmelt was necessary to obtain good agreement between field and simulated moisture contents.

\subsection{Recommendations}

Current snow management practices at the SDA should be reviewed to prevent creation of snow berms over or near waste pits. The NAT W06 simulation suggested that a large amount of water quickly saturated the surficial sediments and moved into the underlying basalt during the 1993 spring thaw. The large snow berm that accumulated from plowing the maintenance was primarily responsible for this infiltration and recharge event.

\subsection{Future Modeling Needs}

Currently, 14 additional NATs are being installed in the SDA with five of these being placed in disturbed areas such as the early waste retrieval pits and cover material over the low-level waste pits. Future modeling efforts at the SDA should include calibrating models to these additional locations. This additional calibration effort would provide a representative numerical data base of hydraulic parameters for the SDA surficial sediments. This data base could then be used to predict future 
overall infiltration rates for the SDA. Predictions using the models in this report and the additional models would be the first "hard" estimates (estimates from models based on observed field conditions) of infiltration amounts and timing available for use in RWMC performance assessment studies.

The travel time for infiltrated water to move through the vadose zone to the aquifer is critical to estimate whether nonsorbing radionuclides pose a threat to aquifer contamination. If travel times are much larger than contaminant half-lives, the threat of contamination is minimal. However, if travel times are shorter or on the order of contaminant half-lives, some remedial action may be necessary, such as removing or preventing snow accumulation within the SDA. As the amount of water entering the vadose zone increases, the travel time through the vadose zone decreases because of higher relative hydraulic conductivities of the wetter soil. The snow berm near NAT W06 in 1993 probably represents an extreme case for an infiltration event resulting from snowmelt.

The amount and timing of water movement into the basalts predicted by the NAT W06 simulation could be used as an upper boundary condition in a vadose zone model that extends to the water table. This model could then be used to predict the extent of water travel times being accelerated by the increased infiltration at NAT W06. Furthermore, data on perched water levels at depths down to $200 \mathrm{ft}$ have been and continue to be collected (Hubbell, 1990; 1993). The data collected indicate that the perched water has a transient behavior that may be correlated to the transient infiltration discussed in this report. The perched water and infiltration data could be used to calibrate the deep vadose zone model with the ultimate goal of also predicting the amounts and timing of water movement to the aquifer. 


\section{REFERENCES}

Anderson, J.E., M.L. Shumar, and N.L. Toft, 1987, "Control of the Soil Water Balance by Sagebrush and Three Perennial Grasses in a Cold-Desert Environment," Arid Soil Research and Rehabilitation, 1, pp. 229-244.

Anderson, J.E., R.S. Nowak, T.D. Ratzlaff, and O.D. Markham, 1991, Managing Soil Moisture on Waste Burial Sites, DOE/ID-12123, U.S. Department of Energy Idaho Operations Office, Idaho Falls, ID.

Baca, R.G. and S.O. Magnuson, 1990, Independent Verification and Benchmark Testing of the UNSATH Computer Code, Version 2.0, EGG-BEG-8811, EG\&G Idaho, Inc., Idaho Falls, ID.

Baca, R.G., S.O. Magnuson, H.D. Nguyen, and P. Martian, 1992, A Modeling Study of Water Flow in the Vadose Zone Beneath the Radioactive Waste Management Complex, EGG-GEO-10068, EG\&G Idaho Inc., Idaho Falls, ID.

Bishop, C.W., 1991, Hydraulic Properties of Vesicular Basalt, Masters Thesis, University of Arizona, Tucson, AZ.

Clawson, K.L. et al., 1989, Climatography of the Idaho National Engineering Laboratory, 2nd Edition, DOE/ID-12118.

Fayer, M.J. and T.L. Jones, 1990, UNSAT-H Version 2.0: Unsaturated Soil Water and Heat Flow Model, PNL-6779, Pacific Northwest Laboratory, Richland, WA.

Fayer, M.J., M.L. Rockhold, and D.J. Holford, 1992, Model Assessment of Protective Barriers: Part III, Status of FY 1990 Work, PNL-7975, Pacific Northwest Laboratory, Richland, WA.

Hubbell, J.M. et al., 1987, Annual Progress Report: FY-1986 Subsurface Investigations Program at the Radioactive Waste Management Complex of the Idaho National Engineering Laboratory, DOE/ID-10153, Idaho Falls, ID.

Hubbell, J.M., 1990, Perched Ground Water at the Radioactive Waste Management Complex of the Idaho National Engineering Laboratory, EGG-ER-8779, EG\&G Idaho, Inc., Idaho Falls, ID.

Hubbell, J.M., 1993, Perched Water Monitoring in the Subsurface Disposal Area of the Radioactive Waste Management Complex, FY-93, ER\&WM-EDF-002293, EG\&G Idaho, Inc., Idaho Falls, ID.

Magnuson, S.O., 1993, A Simulation of Moisture Movement in Proposed Barriers for the Subsurface Disposal Area, INEL, EGG-WM-10974, EG\&G Idaho, Inc., Idaho Falls, ID.

McElroy, D.L., 1990, Vadose Zone Monitoring at the Radioactive Waste Management Complex at the Idaho National Engineering Laboratory 1985-1989, EGG-WM-9299, EG\&G Idaho, Inc., Idaho Falls, ID. 
McElroy, D.L., 1993, Soil Moisture Monitoring Results at the Radioactive Waste Management Complex of the Idaho National Engineering Laboratory, FY-1993, EGG-WM-11066, EG\&G Idaho, Inc., Idaho Falls, ID.

McElroy, D.L. and J.M. Hubbell, 1990, Hydrologic and Physical Properties of Sediments at the Radioactive Waste Management Complex, EGG-BG-9147, EG\&G Idaho, Inc., Idaho Falls, ID.

Richards, L.A., 1931, "Capillary Conduction of Liquids Through Porous Mediums," Physics, 1, pp. 318-333.

Richardson, C.W., and D.A. Wright, 1984, WGEN: A Model for Generating Daily Weather Variables, United States Department of Agriculture (Agriculture Research Service), USDA Report PB85107100.

van Genuchten, M.Th., 1980, "A Closed-Form Equation for Predicting the Hydraulic Conductivity of Unsaturated Soils," Soil Science Society of America Journal, Vol. 44, pp. 892-898.

van Genuchten, M.Th., 1985, RETC.F77: A Program to Analyze Observed Soil Water Tension and Hydraulic Conductivity Data, U.S. Salinity Lab. Spec. Rep. U.S. Salinity Lab., Riverside, CA.

van Genuchten, M.Th., 1988, UNGRA Computer Code, USDA-ARS, U.S. Salinity Laboratory, Riverside, CA. 
Appendix A

Meteorologic Data Base 



\section{Appendix A}

\section{Meteorologic Data Base}

This appendix contains 1991 to 1993 base data from the meteorologic data used in the UNSAT-H calibration simulations. The precipitation received during sub-freezing periods is shifted later to nonfreezing periods. Water application amounts and dates for the increased snowmelt are presented in Table A-1, and the base meteorologic data are presented in Table A-2.

Table A-1. Increased water application amounts and dates.

\begin{tabular}{|c|c|c|c|c|}
\hline \multirow[t]{2}{*}{ Year } & \multicolumn{2}{|c|}{$\begin{array}{l}\text { Daily additional water } \\
\text { (in.) }\end{array}$} & \multicolumn{2}{|c|}{ Application dates } \\
\hline & W02 & W06 & W02 & W06 \\
\hline 1985 & 0.26 & 1.37 & $91-105$ & $91-100$ \\
\hline 1986 & 0.18 & 0.97 & $47-61$ & $47-56$ \\
\hline 1987 & 0.08 & 0.45 & $61-75$ & $61-70$ \\
\hline 1988 & 0.07 & 0.39 & $57-71$ & $57-66$ \\
\hline 1989 & 0.27 & 1.45 & $76-90$ & $76-85$ \\
\hline 1990 & 0.13 & 0.70 & $61-75$ & $61-70$ \\
\hline 1991 & 0.03 & 0.17 & $45-59$ & $45-54$ \\
\hline 1992 & 0.07 & 0.40 & $41-55$ & $41-50$ \\
\hline 1993 & 0.33 & 1.77 & $84-98$ & $84-93$ \\
\hline
\end{tabular}

Table A-2. Base meteorologic data for 1991 to 1993.

Year 1991

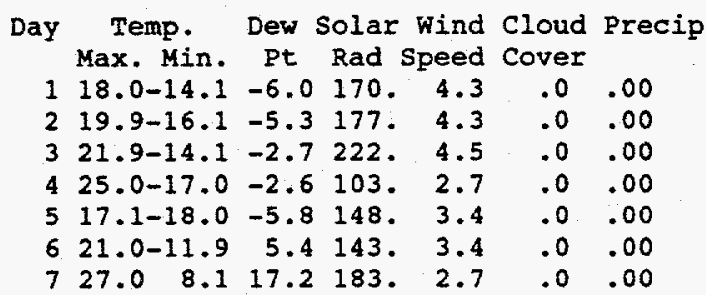

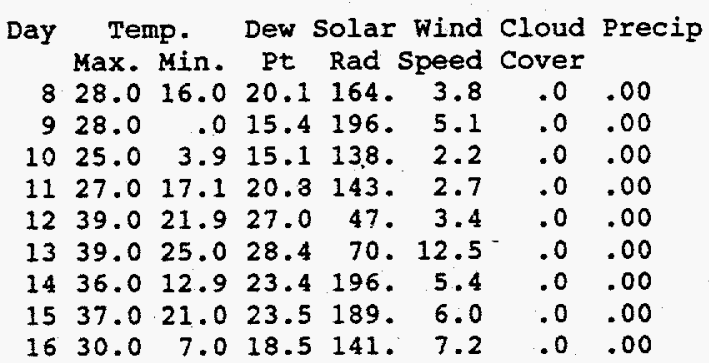


Day Temp. Dew Solar Wind Cloud Precip Max. Min. Pt Rad Speed Cover

$\begin{array}{llllllllllllll}17 & 30.9 & 19.9 & 22.1 & 98 . & 2.2 & .0 & .00\end{array}$

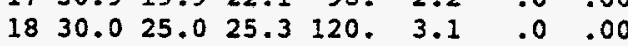

$\begin{array}{lllllllll}19 & 32.0 & -6.0 & 14.0 & 151.10 .7 & .0 & .00\end{array}$

$\begin{array}{lllllll}20 & 23.0-14.1 & -.9224 . & 4.7 & .0 & .00\end{array}$

$\begin{array}{lllllll}21 & 28.0-13.0 & -.2 & 211 . & 5.6 & .0 & .00\end{array}$

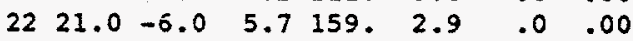

$2326.1-13.0 \quad 3.4 \quad 193.4 .3 .0000$

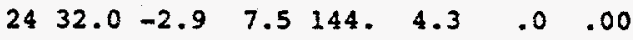

$\begin{array}{lllllllll}25 & 21.0 & -9.0 & -.2 & 234 . & 3.8 & .0 & .00\end{array}$

$\begin{array}{lllllll}26 & 26.1-14.1 & -.6 & 232 & 4.3 & .0 & .00\end{array}$

$\begin{array}{lllllll}27 & 30.9-11.9 & 3.4 & 276 . & 3.4 & .0 & .00\end{array}$

$\begin{array}{lllllll}28 & 21.0-13.0 & .0 & 279 . & 7.2 & .0 & .00\end{array}$

$\begin{array}{llllll}29 & 8.1-18.9-10.7 & 256 . & 5.4 & .0 & .00\end{array}$

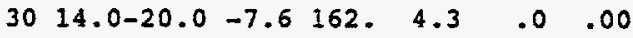

$\begin{array}{lllllllll}31 & 32.0 & -8.0 & 1.6 & 128 . & 3.4 & .0 & .00\end{array}$

$\begin{array}{lllllllll}32 & 39.0 & -6.0 & 5.0 & 197 . & 4.0 & .0 & .00\end{array}$

$\begin{array}{llllllll}33 & 41.0 & -2.9 & 9.9 & 226 . & 4.7 & .0 & .00\end{array}$

$\begin{array}{llllllll}34 & 41.0 & 19.0 & 23.5 & 214 & 3.6 & .0 & .00\end{array}$

$\begin{array}{lllllllllll}35 & 44.1 & 12.9 & 23.0 & 172 & 2.9 & .0 & .00\end{array}$

$\begin{array}{llllllllll}36 & 39.9 & 16.0 & 24.6 & 213 . & 2.9 & .0 & .00\end{array}$

$\begin{array}{llllllllll}37 & 45.0 & 10.0 & 19.8 & 273 . & 4.9 & .0 & .00\end{array}$

$\begin{array}{lllllllllll}38 & 46.0 & 10.0 & 20.5 & 315 . & 4.3 & .0 & .00\end{array}$

$\begin{array}{llllllllllll}39 & 48.0 & 10.0 & 20.8 & 238 . & 2.7 & .0 & .00\end{array}$

$\begin{array}{llllllll}40 & 44.1 & 15.1 & 22.3 & 171 . & 4.5 & .0 & .00\end{array}$

$\begin{array}{lllllllll}41 & 46.9 & 10.9 & 20.1 & 256 . & 4.5 & .0 & .00\end{array}$

$\begin{array}{llllllll}42 & 50.0 & 9.0 & 19.4 & 332 . & 3.6 & .0 & .00\end{array}$

$\begin{array}{llllllllll}43 & 44.1 & 16.0 & 23.9 & 310 . & 8.5 & .0 & .00\end{array}$

$\begin{array}{lllllllll}44 & 48.0 & 26.1 & 29.3 & 256 . & 7.4 & .0 & .28\end{array}$

$\begin{array}{llllllll}45 & 45.0 & 28.0 & 30.2 & 327 . & 3.8 & .0 & .00\end{array}$

$\begin{array}{llllllll}46 & 48.0 & 32.0 & 34.0 & 303 . & 4.0 & .0 & .00\end{array}$

$\begin{array}{lllllllll}47 & 44.1 & 34.0 & 36.1 & 203 . & 6.7 & .0 & .00\end{array}$

$\begin{array}{lllllllll}48 & 41.0 & 23.0 & 19.9 & 246 . & 7.4 & .0 & .00\end{array}$

$\begin{array}{llllllll}49 & 39.0 & 12.9 & 19.2 & 271 . & 7.4 & .0 & .00\end{array}$

$\begin{array}{llllllllll}50 & 43.0 & 19.0 & 24.6 & 312 . & 4.5 & .0 & .00\end{array}$

$\begin{array}{llllllllll}51 & 55.9 & 18.0 & 26.4 & 188 . & 9.6 & .0 & .00\end{array}$

$\begin{array}{lllllllll}52 & 51.1 & 25.0 & 27.9 & 376 . & 6.9 & .0 & .00\end{array}$

$\begin{array}{llllllll}53 & 57.9 & 24.1 & 24.8 & 198 . & 4.5 & .0 & .00\end{array}$

$\begin{array}{llllllll}54 & 48.9 & 19.9 & 20.1 & 255 . & 5.1 & .0 & .00\end{array}$

$\begin{array}{lllllllllll}55 & 45.0 & 18.0 & 14.2 & 143 . & 6.9 & .0 & .00\end{array}$

$\begin{array}{lllllllllllll}56 & 48.0 & 12.9 & 14.4 & 202 & 3.1 & .0 & .00\end{array}$

$\begin{array}{llllllllll}57 & 52.0 & 17.1 & 12.4 & 257 . & 2.7 & .0 & .00\end{array}$

$\begin{array}{lllllllll}58 & 48.0 & 9.0 & 13.6 & 322 . & 4.5 & .0 & .00\end{array}$

$\begin{array}{lllllllll}59 & 44.1 & 8.1 & 21.9 & 249 & 6.7 & .0 & .00\end{array}$

$\begin{array}{lllllllll}60 & 46.9 & 32.0 & 34.0 & 158 . & 9.4 & .0 & .01\end{array}$

$\begin{array}{llllllllll}61 & 48.9 & 34.0 & 31.3 & 183.18 .3 & .0 & .03\end{array}$

$\begin{array}{lllllllll}62 & 45.0 & 30.0 & 34.0 & 272 . & 13.2 & .0 & .15\end{array}$

$\begin{array}{llllllll}63 & 46.0 & 35.1 & 36.9 & 96 . & 12.1 & .0 & .89\end{array}$

$\begin{array}{llllllll}64 & 39.0 & 19.9 & 14.7 & 435 & 16.8 & .0 & .00\end{array}$

$\begin{array}{llllllll}65 & 33.1 & 15.1 & 13.6 & 205 . & 6.5 & .0 & .00\end{array}$

$\begin{array}{lllllllll}66 & 37.0 & 15.1 & 16.0 & 272 . & 11.9 & .0 & .00\end{array}$

$\begin{array}{llllllll}67.43 .0 & 16.0 & 15.4 & 451 . & 7.8 & .0 & .00\end{array}$

$\begin{array}{lllllllll}68 & 48.9 & 12.9 & 18.1 & 405 . & 5.6 & .0 & .00\end{array}$

$\begin{array}{llllllll}69 & 52.0 & 19.9 & 23.5 & 399 . & 9.2 & .0 & .00\end{array}$

$\begin{array}{llllllll}70 & 44.1 & 27.0 & 27.1 & 199 . & 7.5 & .0 & .05\end{array}$

$\begin{array}{lllllllll}71 & 37.9 & 21.9 & 21.7 & 282.10 .1 & .0 & .00\end{array}$

$\begin{array}{llllllllll}72 & 44.1 & 28.0 & 26.6 & 157 . & 4.7 & .0 & .00\end{array}$

$\begin{array}{llllllllll}73 & 45.0 & 25.0 & 27.7 & 351 . & 4.5 & .0 & .01\end{array}$

$\begin{array}{llllllll}74 & 44.1 & 18.0 & 25.2 & 401 . & 4.3 & .0 & .00\end{array}$

$\begin{array}{lllllllllllll}75 & 46.0 & 21.0 & 21.0 & 338 . & 8.7 & .0 & .00\end{array}$
Day Temp. Dew Solar Wind Cloud Precip Max. Min. Pt Rad Speed Cover

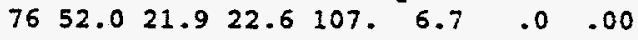

$\begin{array}{lllllllllllll}77 & 55.0 & 21.9 & 22.5 & 283 . & 4.7 & .0 & .00\end{array}$

$\begin{array}{llllllll}78 & 55.9 & 21.9 & 21.7 & 485 & 8.5 & .0 & .00\end{array}$

$\begin{array}{lllllllllll}79 & 46.9 & 19.9 & 23.2 & 307 . & 13.6 & .0 & .00\end{array}$

$\begin{array}{llllllll}80 & 51.1 & 12.9 & 17.8 & 202 . & 4.7 & .0 & .00\end{array}$

$\begin{array}{llllllllll}81 & 50.0 & 19.9 & 18.5 & 479 . & 10.5 & .0 & .00\end{array}$

$\begin{array}{llllllll}82 & 44.1 & 26.1 & 29.5 & 529 & 6.0 & .0 & .03\end{array}$

$\begin{array}{llllllll}83 & 46.928 .923 .7 \quad 534.11 .6 & .0 & .00\end{array}$

$\begin{array}{lllllllllll}84 & 48.0 & 28.9 & 27.0 & 245 . & 9.4 & .0 & .01\end{array}$

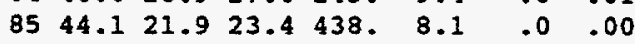

$\begin{array}{llllllll}86 & 46.9 & 21.0 & 19.0 & 271 . & 10.1 & .0 & .00\end{array}$

$8755.0 \quad 19.019 .2 \quad 436.12 .5 \quad .0 \quad .00$

$88 \quad 50.019 .0 \quad 11.5 \quad 542.08 .1 \quad .0 \quad .00$

$8957.0 \quad 14.0 \quad 19.8 \quad 471.05 .1 \quad .0 \quad .00$

$\begin{array}{llllllll}90 & 63.0 & 17.1 & 21.2 & 417 . & 4.5 & .0 & .00\end{array}$

$\begin{array}{lllllllllll}91 & 64.9 & 23.0 & 19.4 & 337 . & 5.1 & .0 & .00\end{array}$

$\begin{array}{llllllll}92 & 63.0 & 26.1 & 26.2 & 372 . & 11.9 & .0 & .00\end{array}$

$\begin{array}{lllllllllll}93 & 60.1 & 24.1 & 20.8 & 436 . & 10.7 & .0 & .00\end{array}$

$\begin{array}{llllllll}94 & 68.0 & 34.0 & 24.8 & 520 . & 9.2 & .0 & .00\end{array}$

$\begin{array}{llllllllll}95 & 69.1 & 45.0 & 23.4 & 550.15 .2 & .0 & .00\end{array}$

$\begin{array}{lllllllll}96 & 59.0 & 37.0 & 30.9 & 300.18 .3 \quad .0 & .00\end{array}$

$\begin{array}{lllllllllll}97 & 50.0 & 23.0 & 18.1 & 385.13 .9 & .0 & .00\end{array}$

$\begin{array}{llllllll}98 & 48.0 & 10.9 & 10.6 & 249 . & 6.7 & .0 & .00\end{array}$

$\begin{array}{lllllllll}99 & 53.1 & 28.0 & 25.0 & 394.13 .4 & .0 & .00\end{array}$

$\begin{array}{llllllll}100 & 43.0 & 25.0 & 14.0 & 482 . & 9.6 & .0 & .00\end{array}$

$\begin{array}{llllllll}101 & 46.0 & 26.1 & 14.0 & 584.16 .8 & .0 & .00\end{array}$

$\begin{array}{llllllll}102 & 46.9 & 35.1 & 16.2 & 466.20 .8 & .0 & .00\end{array}$

$\begin{array}{lllllllll}103 & 48.0 & 25.0 & 15.3 & 568 . & 7.4 & .0 & .00\end{array}$

$\begin{array}{llllllll}104 & 59.0 & 18.0 & 20.1 & 379 . & 9.6 & .0 & .00\end{array}$

$\begin{array}{lllllllllll}105 & 57.0 & 39.0 & 32.4 & 178 . & 6.5 & .0 & .04\end{array}$

$\begin{array}{llllllll}106 & 50.0 & 30.0 & 32.7 & 346 . & 5.8 & .0 & .08\end{array}$

$\begin{array}{llllllll}107 & 55.0 & 25.0 & 28.2 & 479 . & 4.9 & .0 & .07\end{array}$

$\begin{array}{llllllll}108 & 48.9 & 33.1 & 34.5 & 155 . & 5.4 & .0 & .19\end{array}$

$\begin{array}{llllllllllll}109 & 59.0 & 30.0 & 30.4 & 512 . & 3.4 & .0 & .00\end{array}$

$\begin{array}{lllllllllll}110 & 62.1 & 32.0 & 31.1 & 620 . & 6.7 & .0 & .00\end{array}$

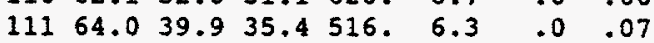

$\begin{array}{lllllllll}112 & 64.9 & 32.0 & 30.6 & 539 . & 4.5 & .0 & .00\end{array}$

$\begin{array}{lllllllll}113 & 66.9 & 34.0 & 33.8 & 483 & 6.0 & .0 & .00\end{array}$

$\begin{array}{llllllll}114 & 59.0 & 37.0 & 35.2 & 652 . & 12.5 & .0 & .00\end{array}$

$\begin{array}{lllllllll}115 & 53.1 & 30.9 & 28.6 & 483 & 14.3 & .0 & .00\end{array}$

$\begin{array}{llllllll}116 & 48.0 & 25.0 & 19.9 & 683 & 6.3 & 6.0 & .00\end{array}$

$\begin{array}{lllllllll}117 & 48.0 & 21.0 & 15.3 & 658 . & 7.8 & .0 & .00\end{array}$

$\begin{array}{lllllllll}118 & 59.0 & 21.0 & 16.7 & 649 . & 6.3 & .0 & .00\end{array}$

$\begin{array}{lllllllll}119 & 46.9 & 32.0 & 29.8 & 698 . & 6.5 & .0 & .06\end{array}$

$\begin{array}{lllllllll}120 & 54.0 & 26.1 & 26.6 & 451 . & 4.0 & .0 & .00\end{array}$

$\begin{array}{lllllllll}121 & 62.1 & 28.9 & 25.3 & 141 . & 13.9 & .0 & .03\end{array}$

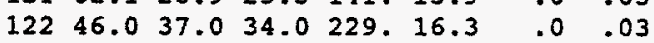

$\begin{array}{llllllll}123 & 45.0 & 34.0 & 32.5 & 279 . & 5.8 & .0 & .01\end{array}$

$\begin{array}{llllllll}124 & 53.1 & 28.0 & 30.4 & 594 . & 4.0 & .0 & .00\end{array}$

$\begin{array}{lllllllll}125 & 64.9 & 24.1 & 29.7 & 464 . & 7.4 & .0 & .00\end{array}$

$\begin{array}{llllllll}126 & 57.0 & 45.0 & 43.0 & 573 & 6.9 & .0 & .22\end{array}$

$\begin{array}{llllllll}127 & 64.0 & 44.1 & 38.8 & 725 . & 7.8 & .0 & .00\end{array}$

$\begin{array}{llllllll}128 & 60.1 & 44.1 & 42.3 & 439 . & 8.9 & .0 & .47\end{array}$

$\begin{array}{llllllll}129 & 48.9 & 39.9 & 37.6 & 708 . & 5.8 & .0 & .44\end{array}$

$\begin{array}{lllllllll}130 & 45.0 & 39.9 & 37.0 & 666 & 5.8 & .0 & .32\end{array}$

$\begin{array}{llllllll}131 & 55.9 & 39.0 & 38.7 & 350 . & 2.9 & .0 & .17\end{array}$

$\begin{array}{lllllllll}132 & 57.0 & 34.0 & 37.4 & 733 . & 4.3 & .0 & .00\end{array}$

$\begin{array}{llllllll}133 & 64.9 & 39.0 & 36.3 & 743 . & 5.8 & .0 & .00\end{array}$

$\begin{array}{llllllll}134 & 64.0 & 41.0 & 40.8 & 436 . & 7.8 & .0 & .02\end{array}$ 
Day Temp. Dew Solar wind Cloud Precip Max. Min. Pt Rad Speed Cover

$\begin{array}{lllllllllll}135 & 68.0 & 42.1 & 35.8 & 726 & 5.8 & .0 & .00\end{array}$

$\begin{array}{llllllllll}136 & 72.0 & 36.0 & 35.8 & 637 . & 4.5 & .0 & .00\end{array}$

$\begin{array}{lllllllll}137 & 71.1 & 45.0 & 42.1 & 416 . & 9.4 & .0 & .02\end{array}$

$\begin{array}{llllllll}138 & 64.0 & 35.1 & 38.5 & 328 . & 11.6 & .0 & .01\end{array}$

$\begin{array}{lllllllllllll}139 & 70.0 & 28.9 & 30.2 & 758 . & 6.5 & .0 & .00\end{array}$

$\begin{array}{lllllllllll}140 & 69.1 & 36.0 & 32.7 & 579 . & 6.3 & .0 & .00\end{array}$

$\begin{array}{llllllllll}141 & 78.1 & 35.1 & 32.2 & 666 . & 5.1 & .0 & .00\end{array}$

$\begin{array}{llllllll}142 & 78.1 & 37.0 & 36.9 & 752 . & 6.5 & .0 & .21\end{array}$

$\begin{array}{lllllllllll}143 & 75.0 & 46.0 & 40.3 & 767 & 6.7 & .0 & .00\end{array}$

$\begin{array}{lllllllll}144 & 77.0 & 37.0 & 34.5 & 657 . & 8.5 & .0 & .00\end{array}$

$\begin{array}{llllllllll}145 & 72.0 & 46.9 & 35.8 & 721.16 .1 & .0 & .00\end{array}$

$\begin{array}{llllllllll}146 & 63.0 & 43.0 & 26.2 & 538 . & 9.2 & .0 & .00\end{array}$

$\begin{array}{llllllllll}147 & 63.0 & 28.9 & 25.9 & 641 . & 6.0 & .0 & .00\end{array}$

$\begin{array}{lllllllll}148 & 66.9 & 25.0 & 25.5 & 553 . & 4.9 & .0 & .00\end{array}$

$\begin{array}{llllllllll}149 & 64.9 & 34.0 & 30.2 & 633 & 10.1 & .0 & .00\end{array}$

$\begin{array}{lllllllll}150 & 63.0 & 42.1 & 38.5 & 779 . & 9.8 & .0 & .08\end{array}$

$\begin{array}{llllllllll}151 & 71.1 & 41.0 & 37.0 & 611.15 .2 & .0 & .00\end{array}$

$\begin{array}{llllllllll}152 & 78.1 & 39.0 & 39.0 & 726 . & 5.4 & .0 & .00\end{array}$

$\begin{array}{llllllllll}153 & 81.0 & 39.9 & 43.7 & 590 . & 6.5 & .0 & .05\end{array}$

$\begin{array}{llllllll}154 & 80.1 & 43.0 & 48.6 & 657 . & 6.9 & .0 & .00\end{array}$

$\begin{array}{lllllllll}155 & 73.9 & 46.0 & 50.2 & 366.6 .9 & .0 & .61\end{array}$

$\begin{array}{llllllll}156 & 51.1 & 45.0 & 43.0 & 266.10 .7 & .0 & .41\end{array}$

$\begin{array}{llllllll}157 & 73.9 & 43.0 & 46.6 & 590 . & 8.9 & .0 & .00\end{array}$

$\begin{array}{lllllllll}158 & 69.1 & 44.1 & 41.0 & 425 . & 15.2 & .0 & .00\end{array}$

$\begin{array}{llllllllll}159 & 73.9 & 37.0 & 42.8 & 681 . & 6.3 & .0 & .00\end{array}$

$\begin{array}{lllllllll}160 & 79.0 & 42.1 & 45.1 & 595 . & 3.6 & .0 & .00\end{array}$

$\begin{array}{lllllllll}161 & 84.9 & 43.0 & 43.5 & 475 . & 4.9 & .0 & .00\end{array}$

$\begin{array}{llllllllll}162 & 86.0 & 43.0 & 44.6 & 485 & 13.0 & .0 & .00\end{array}$

$\begin{array}{lllllllll}163 & 80.1 & 51.1 & 42.1 & 645.14 .1 & .0 & .00\end{array}$

$\begin{array}{llllllllll}164 & 73.0 & 51.1 & 40.3 & 793 . & 15.9 & .0 & .00\end{array}$

$\begin{array}{lllllllll}165 & 64.0 & 42.1 & 37.4 & 687 & 17.0 & .0 & .00\end{array}$

$\begin{array}{lllllllll}166 & 75.9 & 32.0 & 37.9 & 771 . & 6.9 & .0 & .00\end{array}$

$\begin{array}{llllllll}16781.0 & 37.0 & 35.2 & 628.14 .1 & .0 & .00\end{array}$

$\begin{array}{llllllllll}168 & 73.0 & 48.0 & 26.6 & 680 . & 15.4 & .0 & .00\end{array}$

$\begin{array}{llllllllll}169 & 84.0 & 37.0 & 30.9 & 598 . & 6.3 & .0 & .00\end{array}$

$\begin{array}{lllllllll}170 & 84.9 & 60.1 & 40.1 & 612.11 .6 & .0 & .00\end{array}$

$\begin{array}{lllllllll}171 & 75.9 & 48.0 & 37.2 & 538.11 .4 & .0 & .00\end{array}$

$\begin{array}{llllllllll}172 & 80.1 & 41.0 & 36.7 & 794 . & 4.7 & .0 & .00\end{array}$

$\begin{array}{llllllllll}173 & 81.0 & 46.9 & 34.5 & 794 . & 9.6 & .0 & .00\end{array}$

$\begin{array}{llllllll}174 & 86.0 & 48.9 & 41.2 & 692 & 9.6 & .0 & .00\end{array}$

$\begin{array}{lllllllll}175 & 80.1 & 50.0 & 40.8 & 793 . & 7.4 & .0 & .00\end{array}$

$\begin{array}{lllllllll}176 & 73.9 & 45.0 & 40.8 & 691 & 7.2 & .0 & .01\end{array}$

$\begin{array}{llllllll}177 & 70.0 & 37.0 & 37.2 & 773 . & 11.4 & .0 & .00\end{array}$

$\begin{array}{lllllllll}178 & 72.0 & 35.1 & 41.5 & 713 . & 8.3 & .0 & .06\end{array}$

$\begin{array}{llllllll}179 & 73.9 & 51.1 & 43.2 & 791 . & 5.1 & .0 & .01\end{array}$

$\begin{array}{lllllllllll}180 & 75.0 & 46.9 & 42.4 & 619 . & 13.0 & .0 & .00\end{array}$

$\begin{array}{llllllllll}181 & 73.9 & 46.0 & 43.5 & 790.12 .5 & .0 & .00\end{array}$

$\begin{array}{lllllllllll}182 & 82.9 & 36.0 & 37.4 & 789 & 5.4 & .0 & .00\end{array}$

$\begin{array}{lllllllll}183 & 89.1 & 44.1 & 39.7 & 764 . & 5.6 & .0 & .00\end{array}$

$\begin{array}{lllllllll}184 & 93.9 & 45.0 & 37.4 & 611.6 .0 & .0 & .00\end{array}$

$\begin{array}{lllllllll}185 & 97.0 & 46.0 & 36.1 & 670.10 .5 & .0 & .00\end{array}$

$\begin{array}{lllllllll}186 & 95.0 & 53.1 & 34.9 & 540.15 .0 & .0 & .00\end{array}$

$\begin{array}{llllllll}187 & 91.9 & 55.9 & 34.0 & 783.12 .5 & .0 & .00\end{array}$

$\begin{array}{lllllllll}188 & 91.0 & 48.9 & 31.3 & 686 . & 9.2 & .0 & .00\end{array}$

$\begin{array}{lllllllll}189 & 93.9 & 46.9 & 32.7 & 570 . & 8.5 & .0 & .00\end{array}$

$\begin{array}{llllllllll}190 & 90.0 & 53.1 & 45.1 & 638 . & 9.6 & .0 & .00\end{array}$

$\begin{array}{lllllllll}191 & 86.0 & 54.0 & 39.2 & 709.10 .1 & .0 & .00\end{array}$

$\begin{array}{llllllllll}192 & 88.0 & 43.0 & 32.9 & 776 . & 5.8 & .0 & .00\end{array}$

$\begin{array}{llllllllll}193 & 93.9 & 45.0 & 38.1 & 775 . & 5.6 & .0 & .00\end{array}$
Day Temp. Dew Solar wind Cloud Precip Max. Min. Pt Rad Speed Cover

$\begin{array}{lllllllllllllll}194 & 95.0 & 51.1 & 41.4 & 753 & 7.8 & .0 & .00\end{array}$

$\begin{array}{llllllllll}195 & 93.9 & 62.1 & 43.0 & 760.10 .1 & .0 & .00\end{array}$

$\begin{array}{llllllllll}196 & 95.0 & 52.0 & 39.9 & 714 & 7.8 & .0 & .00\end{array}$

$\begin{array}{llllllll}197 & 93.9 & 51.1 & 36.3 & 767 . & 9.4 & .0 & .00\end{array}$

$\begin{array}{llllllll}198 & 88.0 & 46.9 & 37.6 & 709.12 .3 & .0 & .00\end{array}$

$19987.1 \quad 52.0 \quad 37.4 \quad 458.13 .9 \quad .0 \cdot .00$

$\begin{array}{llllllllll}200 & 87.1 & 48.9 & 40.6 & 589.10 .1 & .0 & .00\end{array}$

$\begin{array}{lllllllll}201 & 87.1 & 51.1 & 48.4 & 653 & 7.2 & .0 & .00\end{array}$

$\begin{array}{llllllllll}202 & 88.0 & 46.0 & 47.3 & 512 & 6.3 & .0 & .00\end{array}$

$\begin{array}{llllllllll}203 & 91.0 & 46.9 & 46.6 & 701 . & 6.5 & .0 & .00\end{array}$

$\begin{array}{lllllllll}204 & 89.1 & 55.0 & 50.4 & 441 . & 8.5 & .0 & .06\end{array}$

$\begin{array}{llllllll}205 & 87.1 & 54.0 & 52.9 & 482 . & 8.1 & .0 & .04\end{array}$

$\begin{array}{llllllll}206 & 78.1 & 52.0 & 51.8 & 723 . & 8.1 & .0 & .40\end{array}$

$\begin{array}{lllllllll}207 & 84.9 & 46.0 & 46.9 & 670 . & 5.8 & .0 & .00\end{array}$

$\begin{array}{llllllllllll}208 & 90.0 & 46.9 & 44.1 & 493 . & 3.8 & .0 & .00\end{array}$

$\begin{array}{llllllllll}209 & 95.0 & 46.9 & 44.1 & 560 . & 3.8 & .0 & .00\end{array}$

$\begin{array}{lllllllll}210 & 96.1 & 50.0 & 41.4 & 628 . & 1.8 & .0 & .03\end{array}$

$\begin{array}{lllllllll}211.95 .0 & 48.0 & 44.4 & 605 . & 5.6 & .0 & .00\end{array}$

$\begin{array}{llllllllll}212 & 91.9 & 53.1 & 45.1 & 730.7 .8 & .0 & .00\end{array}$

$\begin{array}{llllllll}213 & 88.0 & 57.0 & 37.2 & 727 & 13.0 & .0 & .00\end{array}$

$\begin{array}{llllllll}214 & 89.1 & 42.1 & 31.6 & 657 & 5.8 & .0 & .00\end{array}$

$\begin{array}{llllllllll}215 & 90.0 & 48.9 & 34.0 & 665 . & 6.5 & .0 & .00\end{array}$

$\begin{array}{lllllllllll}216 & 84.9 & 59.0 & 40.8 & 626 . & 7.6 & .0 & .00\end{array}$

$\begin{array}{lllllllll}217 & 87.1 & 57.0 & 47.8 & 561 . & 7.4 & .0 & .00\end{array}$

$\begin{array}{llllllllll}218 & 90.0 & 48.9 & 44.1 & 228 . & 7.4 & .0 & .03\end{array}$

$\begin{array}{lllllllll}219 & 91.9 & 46.9 & 39.6 & 537 . & 7.4 & .0 & .00\end{array}$

$\begin{array}{lllllllll}220 & 95.0 & 45.0 & 32.9 & 549 . & 5.1 & .0 & .00\end{array}$

$\begin{array}{lllllllllll}221 & 95.0 & 45.0 & 31.8 & 459 . & 5.4 & .0 & .00\end{array}$

$\begin{array}{llllllllll}222 & 91.0 & 50.0 & 39.4 & 434 . & 9.6 & .0 & .00\end{array}$

$22391.0 \quad 55.0 \quad 34.7 \quad 433.8 .7 .000$

$22490.054 .0 \quad 28.6 \quad 465.10 .3 \quad .0 \quad .00$

$\begin{array}{lllllllll}225 & 91.9 & 46.0 & 31.6 & 448.10 .3 & .0 & .00\end{array}$

$\begin{array}{llllllll}226 & 90.0 & 64.0 & 37.6 & 453 & 12.5 & .0 & .00\end{array}$

$22784.0 \quad 55.947 .8651 .6 .7 \quad .0 \quad .00$

$\begin{array}{llllllllll}228 & 82.0 & 48.9 & 52.5 & 454 & 6.5 & 6.0 & .11\end{array}$

$\begin{array}{lllllllllll}229 & 88.0 & 45.0 & 46.2 & 670 . & 5.1 & .0 & .00\end{array}$

$\begin{array}{llllllll}230 & 93.0 & 50.0 & 43.9 & 666 . & 6.9 & .0 & .00\end{array}$

$\begin{array}{lllllllll}231 & 88.0 & 57.9 & 50.0 & 500 . & 7.8 & .0 & .03\end{array}$

$\begin{array}{llllllll}232 & 91.0 & 44.1 & 48.4 & 471 . & 5.4 & .0 & .00\end{array}$

$\begin{array}{lllllllll}233 & 95.0 & 46.9 & 43.5 & 611 . & 5.6 & .0 & .00\end{array}$

$\begin{array}{lllllllll}234 & 95.0 & 45.0 & 41.0 & 537 . & 5.8 & .0 & .00\end{array}$

$\begin{array}{llllllllll}235 & 96.1 & 55.9 & 37.9 & 601 & 10.3 & .0 & .02\end{array}$

$\begin{array}{lllllllll}236 & 93.9 & 54.0 & 32.4 & 543 . & 9.6 & .0 & .00\end{array}$

$\begin{array}{llllllll}237 & 91.9 & 55.9 & 45.5 & 190 & 7.4 & .0 & .01\end{array}$

$\begin{array}{llllllllll}238 & 84.9 & 54.0 & 54.1 & 632 . & 8.7 & .0 & .00\end{array}$

$\begin{array}{llllllllll}239 & 90.0 & 59.0 & 53.2 & 508 . & 9.2 & .0 & .58\end{array}$

$\begin{array}{lllllllll}240 & 75.9 & 51.1 & 46.4 & 456 . & 9.4 & .0 & .00\end{array}$

$\begin{array}{lllllllll}241 & 87.1 & 42.1 & 39.6 & 618,5.1 & .0 & .00\end{array}$

$\begin{array}{llllllll}242 & 93.9 & 44.1 & 37.8 & 614 . & 5.8 & .0 & .00\end{array}$

$\begin{array}{lllllllll}243 & 93.0 & 46.9 & 40.3 & 573 . & 8.3 & .0 & .00\end{array}$

$\begin{array}{llllllll}244 & 90.0 & 54.0 & 44.6 & 502 . & 9.2 & .0 & .00\end{array}$

$\begin{array}{llllllll}245 & 87.1 & 50.0 & 40.1 & 577.11 .0 & .0 & .00\end{array}$

$\begin{array}{lllllll}24684.9 & 45.0 & 37.2 & 545.4 & 4.5 & .0 & .00\end{array}$

$\begin{array}{lllllllll}24788.0 & 43.0 & 36.1 & 587 . & 4.7 & .0 & .00\end{array}$

$\begin{array}{llllllllll}248 & 89.1 & 42.1 & 35.6 & 586 . & 4.5 & .0 & .00\end{array}$

$\begin{array}{llllllllll}249 & 91.9 & 42.1 & 37.9 & 544 . & 6.3 & .0 & .00\end{array}$

$\begin{array}{llllllllll}250 & 84.0 & 53.1 & 54.1 & 398 . & 5.8 & .0 & .22\end{array}$

$\begin{array}{llllllllll}25173.0 & 54.0 & 50.4 & 194 . & 9.4 & .0 & .02\end{array}$

$\begin{array}{llllllll}252 & 69.1 & 46.9 & 48.7 & 273 & 8.1 & 8.0 & .48\end{array}$ 
Day Temp. Dew Solar wind Cloud Precip Max. Min. Pt Rad Speed Cover

$\begin{array}{llllllllll}253 & 63.0 & 50.0 & 50.4 & 359 & 8.3 & .0 & .16\end{array}$

$\begin{array}{llllllll}254 & 62.1 & 45.0 & 45.7 & 297 . & 4.5 & .0 & .10\end{array}$

$\begin{array}{lllllllllll}255 & 70.0 & 37.0 & 42.4 & 464 . & 3.4 & .0 & .00\end{array}$

$\begin{array}{lllllllll}256 & 73.9 & 37.9 & 43.2 & 521 & 8.3 & .0 & .00\end{array}$

$\begin{array}{lllllllll}257 & 57.9 & 41.0 & 33.1 & 349.10 .7 & .0 & .00\end{array}$

$\begin{array}{llllllllll}258 & 66.0 & 30.0 & 30.4 & 536 . & 4.5 & .0 & .00\end{array}$

$\begin{array}{llllllllll}259 & 75.0 & 30.9 & 33.8 & 451 . & 5.4 & .0 & .00\end{array}$

$\begin{array}{lllllllll}260 & 72.0 & 37.9 & 36.0 & 244 . & 8.7 & .0 & .00\end{array}$

$\begin{array}{llllllllll}261 & 71.1 & 39.0 & 27.9 & 444 . & 7.4 & .0 & .00\end{array}$

$\begin{array}{lllllllll}262 & 82.0 & 35.1 & 30.0 & 455 . & 4.5 & .0 & .00\end{array}$

$26384.034 .0 \quad 31.8384 .7 .4 \quad .0 \quad .00$

$\begin{array}{lllllllll}264 & 70.0 & 45.0 & 23.5 & 495.14 .1 & .0 & .00\end{array}$

$\begin{array}{lllllllllll}265 & 66.0 & 32.0 & 19.2 & 501 . & 6.0 & .0 & .00\end{array}$

$\begin{array}{lllllllll}266 & 73.0 & 30.9 & 22.6 & 446 . & 4.0 & .0 & .00\end{array}$

$\begin{array}{lllllllll}267 & 79.0 & 32.0 & 27.5 & 393 . & 4.7 & .0 & .00\end{array}$

$\begin{array}{llllllll}268 & 84.0 & 32.0 & 29.8 & 485 . & 4.5 & .0 & .00\end{array}$

$\begin{array}{llllllllll}269 & 84.9 & 32.0 & 27.7 & 480 & 3.8 & .0 & .00\end{array}$

$\begin{array}{lllllllll}270 & 86.0 & 34.0 & 29.8 & 475 . & 4.5 & .0 & .00\end{array}$

$\begin{array}{lllllllll}271 & 73.0 & 54.0 & 48.0 & 298 . & 7.8 & .0 & .10\end{array}$

$\begin{array}{lllllllll}272 & 72.0 & 46.0 & 47.3 & 465 . & 4.5 & .0 & .00\end{array}$

$\begin{array}{lllllllllll}273 & 78.1 & 35.1 & 40.1 & 368 & 6.3 & .0 & .00\end{array}$

$\begin{array}{lllllllll}274 & 82.0 & 36.0 & 35.6 & 199 & 10.3 & .0 & .00\end{array}$

$\begin{array}{llllllll}275 & 75.9 & 39.0 & 28.6 & 298 . & 9.2 & .0 & .00\end{array}$

$\begin{array}{lllllllll}276 & 70.0 & 35.1 & 18.7 & 239 & 10.5 & .0 & .00\end{array}$

$\begin{array}{llllllllll}277 & 61.0 & 19.9 & 18.5 & 343 . & 4.5 & .0 & .00\end{array}$

$\begin{array}{llllllll}278 & 69.1 & 19.0 & 13.8 & 324 . & 3.6 & .0 & .00\end{array}$

$\begin{array}{llllllllll}279 & 77.0 & 23.0 & 16.9 & 412 . & 4.7 & .0 & .00\end{array}$

$\begin{array}{llllllll}280 & 75.9 & 32.0 & 22.3 & 418 . & 5.6 & .0 & .00\end{array}$

$\begin{array}{lllllllllll}281 & 77.0 & 30.0 & 24.4 & 419 . & 5.1 & .0 & .00\end{array}$

$\begin{array}{lllllllll}282 & 79.0 & 27.0 & 23.7 & 366 . & 4.3 & .0 & .00\end{array}$

$\begin{array}{lllllllll}283 & 84.0 & 33.1 & 25.5 & 208 . & 4.5 & .0 & .00\end{array}$

$28482.932 .026 .8163 .44 .9 \quad .0 \quad .00$

$\begin{array}{llllllllll}285 & 81.0 & 30.9 & 24.3 & 267 . & 9.8 & .0 & .00\end{array}$

$\begin{array}{lllllllll}286 & 71.1 & 39.0 & 22.8 & 325 & 7.2 & .0 & .00\end{array}$

$\begin{array}{llllllll}287 & 77.0 & 32.0 & 23.9 & 364 . & 5.6 & .0 & .00\end{array}$

$\begin{array}{lllllllll}288 & 79.0 & 28.9 & 27.1 & 377 . & 5.4 & .0 & .00\end{array}$

$\begin{array}{lllllllll}289 & 75.9 & 28.9 & 27.3 & 222 & 13.4 & .0 & .00\end{array}$

$\begin{array}{llllllllll}290 & 64.9 & 39.0 & 28.4 & 241.20 .1 & .0 & .00\end{array}$

$\begin{array}{llllllllll}291 & 55.0 & 19.0 & 17.2 & 317 & 4.7 & .0 & .00\end{array}$

$\begin{array}{lllllllllll}292 & 57.0 & 26.1 & 16.9 & 235 . & 2.7 & .0 & .00\end{array}$

$\begin{array}{llllllll}293 & 64.0 & 21.0 & 22.6 & 363 . & 4.5 & .0 & .00\end{array}$

$\begin{array}{lllllllllll}294 & 66.9 & 25.0 & 33.3 & 357 . & 16.3 & .0 & .00\end{array}$

$\begin{array}{lllllllll}295 & 57.9 & 43.0 & 37.2 & 208.14 .3 & .0 & .03\end{array}$

$\begin{array}{lllllllll}296 & 45.0 & 25.0 & 30.9 & 277 . & 12.3 & .0 & .00\end{array}$

$\begin{array}{lllllllll}297 & 43.0 & 16.0 & 21.9 & 287 . & 8.9 & .0 & .00\end{array}$

$\begin{array}{llllllll}298 & 39.9 & 30.9 & 32.9 & 152 . & 9.2 & .0 & .03\end{array}$

$\begin{array}{llllllll}299 & 46.0 & 37.0 & 40.1 & 67 . & 13.2 & .0 & .22\end{array}$

$\begin{array}{llllllll}300 & 39.9 & 12.9 & 32.2 & 66 . & 9.8 & .0 & .00\end{array}$

$\begin{array}{lllllllll}301 & 34.0 & 5.0 & 18.3 & 102 . & 4.0 & .0 & .00\end{array}$

$\begin{array}{llllllllll}302 & 30.0 & 16.0 & 16.7 & 141 . & 12.3 & .0 & .00\end{array}$

$\begin{array}{llllllllll}303 & 30.0 & 1.0 & 12.2 & 249 . & 7.2 & .0 & .00\end{array}$

$\begin{array}{llllllll}304 & 28.9 & 21.0 & 21.2 & 185 & 4.3 & .0 & .00\end{array}$

$\begin{array}{lllllllll}305 & 27.0 & 9.0 & 14.5 & 117 . & 11.4 & .0 & .00\end{array}$

$\begin{array}{llllllll}306 & 28.0 & -2.0 & 1.4 & 242 . & 5.4 & .0 & .00\end{array}$

$\begin{array}{lllllllll}307 & 23.0 & -2.0 & 6.1 & 221 . & 4.0 & .0 & .00\end{array}$

$\begin{array}{lllllllll}308 & 28.0 & 10.0 & 13.5 & 153 . & 3.1 & .0 & .00\end{array}$

$\begin{array}{llllllllll}309 & 37.9 & 21.0 & 26.1 & 264 . & 3.8 & .0 & .00\end{array}$

$\begin{array}{llllllllll}310 & 36.0 & 23.0 & 29.7 & 294 . & 3.6 & .0 & .00\end{array}$

$\begin{array}{llllllll}311 & 41.0 & 24.1 & 28.9 & 290 . & 4.3 & .0 & .03\end{array}$
Day Temp. Dew Solar Wind Cloud Precip Max. Min. Pt Rad speed Cover

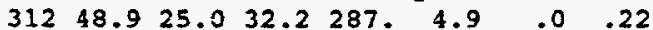

$\begin{array}{llllllll}313 & 54.0 & 36.0 & 38.7 & 57 . & 5.1 & .0 & .03\end{array}$

$\begin{array}{lllllllll}314 & 46.928 .9 & 34.3 & 280 & 2.9 & .0 & .00\end{array}$

$\begin{array}{lllllllllll}315 & 45.0 & 25.0 & 30.4 & 220 & 2.5 & .0 & .00\end{array}$

$\begin{array}{llllllllll}316 & 55.0 & 21.0 & 31.3 & 274 . & 4.9 & .0 & .00\end{array}$

$\begin{array}{lllllllll}317 & 45.0 & 37.0 & 37.8 & 158 . & 8.5 & .0 & .18\end{array}$

$\begin{array}{llllllll}318 & 42.1 & 30.9 & 22.8 & 268 & 15.0 & .0 & .00\end{array}$

$\begin{array}{llllllllll}319 & 44.1 & 19.0 & 17.8 & 225 . & 9.8 & .0 & .00\end{array}$

$\begin{array}{llllllllll}320 & 43.0 & 12.0 & 19.0 & 256 . & 3.8 & .0 & .00\end{array}$

$\begin{array}{llllllll}321 & 34.0 & 17.1 & 28.2 & 52 . & 4.0 & .0 & .00\end{array}$

$\begin{array}{llllllllll}322 & 37.9 & 21.9 & 27.5 & 93 . & 6.7 & .0 & .00\end{array}$

$\begin{array}{llllllll}323 & 34.0 & 9.0 & 20.8 & 58 . & 3.6 & .0 & .00\end{array}$

$\begin{array}{llllllll}324 & 39.9 & 21.0 & 29.7 & 204 . & 8.3 & .0 & .00\end{array}$

$\begin{array}{llllllll}325 & 39.9 & 21.9 & 21.6 & 153 . & 9.8 & .0 & .00\end{array}$

$\begin{array}{llllllllll}326 & 35.1 & 10.0 & 12.4 & 246 . & 4.7 & .0 & .00\end{array}$

$\begin{array}{lllllllll}327 & 24.1 & .0 & 10.9 & 112 . & 4.3 & .0 & .00\end{array}$

$\begin{array}{llllllll}328 & 28.0 & 17.1 & 21.2 & 48 . & 3.4 & .0 & .00\end{array}$

$\begin{array}{llllllll}329 & 30.0 & 21.9 & 25.7 & 86 . & 2.2 & .0 & .00\end{array}$

$\begin{array}{lllllllll}330 & 36.0 & 12.9 & 25.7 & 48 . & 4.3 & .0 & .00\end{array}$

$\begin{array}{llllllll}331 & 37.0 & 23.0 & 29.5 & 47 . & 9.6 & .0 & .00\end{array}$

$\begin{array}{llllllll}332 & 32.0 & 12.0 & 18.5 & 188 . & 8.1 & .0 & .00\end{array}$

$\begin{array}{llllllll}333 & 30.9 & 12.9 & 14.9 & 69 . & 13.9 & .0 & .00\end{array}$

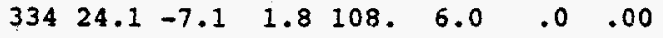

$\begin{array}{llllllll}335 & 23.0 & -8.0 & 3.6 & 160 . & 4.7 & .0 & .00\end{array}$

$\begin{array}{llllllll}336 & 37.0 & 8.1 & 12.9 & 155 . & 3.8 & .0 & .00\end{array}$

$\begin{array}{llllllllll}337 & 28.9 & 3.0 & 14.7 & 108 . & 3.6 & .0 & .00\end{array}$

$\begin{array}{llllllllll}338 & 35.1 & 10.0 & 18.9 & 224 . & 3.1 & .0 & .00\end{array}$

$\begin{array}{llllllllll}339 & 36.0 & 7.0 & 16.7 & 208 . & 2.9 & .0 & .00\end{array}$

$\begin{array}{llllllll}340 & 45.0 & 24.1 & 27.9 & 133 . & 9.2 & .0 & .15\end{array}$

$\begin{array}{lllllllll}341 & 46.9 & 28.9 & 30.9 & 123 & 10.1 & .0 & .35\end{array}$

$\begin{array}{llllllll}342 & 32.0 & 21.0 & 23.5 & 219 . & 8.1 & .0 & .00\end{array}$

$\begin{array}{llllllllllll}343 & 30.9 & 17.1 & 23.0 & 218 . & 3.1 & .0 & .00\end{array}$

$\begin{array}{llllllll}344 & 35.1 & 17.1 & 20.7 & 217 . & 4.0 & .0 & .00\end{array}$

$\begin{array}{lllllllllllll}345 & 21.9 & 15.1 & 19.4 & 204 & 2.2 & .0 & .00\end{array}$

$\begin{array}{lllllllll}346 & 33.1 & 18.0 & 21.7 & 197 . & 8.9 & .0 & .00\end{array}$

$\begin{array}{lllllllll}347 & 32.0 & 5.0 & 13.1 & 168 . & 6.9 & .0 & .00\end{array}$

$\begin{array}{llllllll}348 & 26.1 & 1.0 & 7.3 & 136 . & 3.8 & .0 & .00\end{array}$

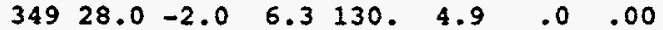

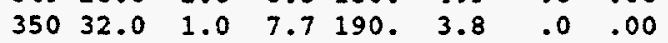

$\begin{array}{llllllll}351 & 35.1 & 1.0 & 9.3 & 143 . & 4.7 & .0 & .00\end{array}$

$\begin{array}{llllllllll}352 & 30.0 & 7.0 & 18.1 & 142 . & 2.9 & .0 & .00\end{array}$

$\begin{array}{llllllll}353 & 36.0 & 7.0 & 19.9 & 186 . & 5.1 & .0 & .00\end{array}$

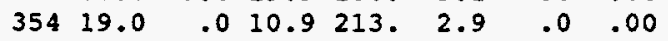

$\begin{array}{llllllll}355 & 24.1 & 1.0 & 9.3 & 213 & 4.9 & .0 & .00\end{array}$

$\begin{array}{llllllll}356 & 30.9 & .0 & 1.2 & 164 . & 3.8 & .0 & .00\end{array}$

$\begin{array}{llllllllll}357 & 30.9 & 1.0 & 12.6 & 124 . & 4.7 & .0 & .00\end{array}$

$\begin{array}{lllllllll}358 & 35.1 & 3.0 & 11.5 & 185 . & 4.3 & .0 & .00\end{array}$

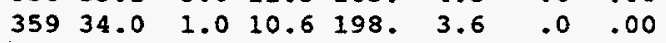

$\begin{array}{llllllllll}360 & 34.0 & 1.0 & 10.6 & 215 . & 4.3 & .0 & .00\end{array}$

$\begin{array}{llllllll}361 & 33.1 & 1.9 & 11.8 & 189 . & 4.7 & .0 & .00\end{array}$

$\begin{array}{llllllllll}362 & 36.0 & 1.9 & 11.8 & 216 . & 4.0 & .0 & .00\end{array}$

$\begin{array}{llllllll}363 & 33.1 & 21.0 & 23.2 & 217 . & 4.0 & .0 & .00\end{array}$

$\begin{array}{lllllllll}364 & 35.1 & 12.9 & 20.3 & 207 . & 3.6 & .0 & .00\end{array}$

$\begin{array}{lllllllll}365 & 37.0 & 8.1 & 21.2 & 164 . & 2.9 & .0 & .00\end{array}$ 
Year 1992

Day Temp. Dew Solar Wind Cloud Precip Max. Min. Pt Rad Speed Cover

$\begin{array}{llllllllll}126.1 & 12.0 & 21.2 & 170 . & 2.2 & .0 & .00\end{array}$

$\begin{array}{llllllll}2 & 30.0 & 6.1 & 17.2 & 177 . & 2.5 & .0 & .00\end{array}$

$\begin{array}{llllllll}3 & 32.0 & -.9 & 9.3 & 222 . & 3.8 & .0 & .00\end{array}$

$\begin{array}{llllllll}4 & 33.1 & 10.9 & 21.2 & 103 . & 4.7 & .0 & .00\end{array}$

$\begin{array}{llllllll}5 & 32.0 & 18.0 & 24.3 & 148 . & 5.6 & .0 & .00\end{array}$

$\begin{array}{lllllllll}6 & 36.0 & 25.0 & 28.8 & 143 . & 4.7 & .0 & .00\end{array}$

$\begin{array}{llllllll}732.0 & 19.9 & 26.6 & 183 . & 9.6 & .0 & .00\end{array}$

$\begin{array}{lllllllllll}8 & 25.0 & 12.9 & 21.0 & 164 . & 6.5 & .0 & .00\end{array}$

$\begin{array}{lllllllllll}9 & 25.0 & 7.0 & 14.2 & 196 . & 3.8 & .0 & .00\end{array}$

$\begin{array}{llllllll}10 & 28.9 & 1.0 & 7.3 & 138 . & 4.7 & .0 & .00\end{array}$

$\begin{array}{lllllllll}11 & 33.1 & -.9 & 9.0 & 143 . & 4.0 & .0 & .00\end{array}$

$\begin{array}{llllllll}12 & 35.1 & -2.0 & 6.3 & 153 . & 4.5 & .0 & .00\end{array}$

$\begin{array}{llllllll}13 & 23.0 & 3.9 & 14.9 & 70 . & 2.2 & .0 & .00\end{array}$

$\begin{array}{llllllllll}14 & 28.0 & 5.0 & 18.3 & 196 . & 7.2 & .0 & .00\end{array}$

$\begin{array}{lllllllll}15 & 21.9 & -5.1 & 5.4 & 189 . & 4.5 & .0 & .00\end{array}$

$\begin{array}{llllllll}16 & 27.0 & 3.9 & 16.0 & 141 . & 3.4 & .0 & .00\end{array}$

$\begin{array}{llllllll}17 & 35.1 & 1.0 & 12.0 & 98 . & 3.8 & .0 & .00\end{array}$

$\begin{array}{llllllllll}18 & 28.0 & -.9 & 6.1 & 120 . & 3.4 & .0 & .00\end{array}$

$\begin{array}{llllllllll}19 & 30.0 & -6.0 & 3.2 & 151 . & 4.7 & .0 & .00\end{array}$

$\begin{array}{llllllllll}20 & 32.0 & -5.1 & 3.2 & 224 . & 4.9 & .0 & .00\end{array}$

$\begin{array}{llllllll}21 & 28.9 & -7.1 & 2.1 & 211 . & 3.8 & .0 & .00\end{array}$

$\begin{array}{lllllllll}22 & 25.0 & -2.0 & 5.7 & 159 . & 4.0 & .0 & .00\end{array}$

$\begin{array}{lllllllll}23 & 39.0 & 1.9 & 14.0 & 193 . & 3.8 & .0 & .00\end{array}$

$\begin{array}{llllllllllll}24 & 48.0 & 10.0 & 18.1 & 144 & 6.5 & .0 & .00\end{array}$

$\begin{array}{lllllllll}25 & 45.0 & 12.9 & 21.4 & 234 . & 5.4 & .0 & .00\end{array}$

$\begin{array}{llllllll}26 & 37.9 & 8.1 & 18.0 & 232 . & 4.0 & .0 & .00\end{array}$

$\begin{array}{lllllllll}27 & 42.1 & 9.0 & 16.9 & 276 . & 3.6 & .0 & .00\end{array}$

$\begin{array}{llllllllll}28 & 43.0 & 15.1 & 24.8 & 279 . & 7.4 & .0 & .00\end{array}$

$\begin{array}{lllllllll}29 & 39.9 & 15.1 & 25.0 & 256 . & 3.4 & .0 & .00\end{array}$

$\begin{array}{lllllllllll}30 & 39.0 & 12.9 & 19.9 & 162 . & 3.8 & .0 & .00\end{array}$

$\begin{array}{llllllllll}31 & 45.0 & 7.0 & 14.9 & 128 . & 4.5 & .0 & .00\end{array}$

$\begin{array}{llllllllllllll}32 & 50.0 & 9.0 & 16.9 & 197 . & 4.3 & .0 & .00\end{array}$

$\begin{array}{llllllllll}33 & 42.1 & 14.0 & 19.4 & 226 . & 3.6 & .0 & .00\end{array}$

$\begin{array}{llllllllll}34 & 46.0 & 10.9 & 17.1 & 214 . & 5.6 & .0 & .00\end{array}$

$\begin{array}{llllllllllll}35 & 44.1 & 9.0 & 12.9 & 172 & 5.1 & .0 & .00\end{array}$

$\begin{array}{lllllllll}36 & 41.0 & 3.9 & 11.5 & 213 . & 4.3 & .0 & .00\end{array}$

$\begin{array}{lllllllll}37 & 37.9 & 5.0 & 12.6 & 273 & 5.4 & .0 & .00\end{array}$

$\begin{array}{lllllllll}38 & 44.1 & 6.1 & 13.5 & 315 . & 4.5 & .0 & .00\end{array}$

$\begin{array}{llllllllll}39 & 46.0 & 21.0 & 24.1 & 238 . & 4.7 & .0 & .00\end{array}$

$\begin{array}{llllllllll}40 & 42.1 & 12.9 & 23.4 & 171 . & 4.5 & .0 & .00\end{array}$

$\begin{array}{llllllllll}41 & 43.0 & 23.0 & 30.7 & 256 . & 4.7 & .0 & .00\end{array}$

$\begin{array}{llllllllll}42 & 48.9 & 28.9 & 33.6 & 332 & 3.8 & .0 & .00\end{array}$

$\begin{array}{lllllllll}43 & 45.0 & 32.0 & 32.9 & 310.04 .9 & .0 & .00\end{array}$

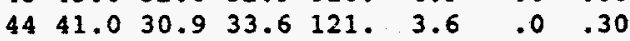

$\begin{array}{llllllllll}45 & 43.0 & 19.9 & 28.8 & 327 . & 6.3 & .0 & .00\end{array}$

$\begin{array}{llllllll}46 & 44.1 & 26.1 & 29.5 & 303 . & 4.7 & .0 & .00\end{array}$

$\begin{array}{llllllll}47 & 37.0 & 28.9 & 28.6 & 203 . & 10.7 & .0 & .00\end{array}$

$\begin{array}{llllllll}48 & 39.9 & 21.0 & 21.2 & 246 . & 6.9 & .0 & .00\end{array}$

$\begin{array}{llllllll}49 & 41.0 & 23.0 & 11.8 & 135 . & 5.6 & .0 & .00\end{array}$

$\begin{array}{llllllllll}50 & 43.0 & 32.0 & 32.9 & 312 . & 12.5 & .0 & .10\end{array}$

$\begin{array}{lllllllll}51 & 51.1 & 37.9 & 37.9 & 188 . & 14.3 & .0 & .00\end{array}$

$\begin{array}{lllllllll}52 & 43.0 & 32.0 & 34.0 & 376 . & 8.1 & .0 & .00\end{array}$

$\begin{array}{lllllllll}53 & 48.9 & 30.0 & 32.2 & 198 . & 7.4 & .0 & .00\end{array}$

$\begin{array}{llllllllll}54 & 48.0 & 28.0 & 21.4 & 255 . & 7.2 & .0 & .00\end{array}$

$\begin{array}{llllllllllll}55 & 37.9 & 24.1 & 27.1 & 143 . & 3.1 & .0 & .00\end{array}$

$\begin{array}{lllllllllll}56 & 50.0 & 21.0 & 28.0 & 202 . & 3.1 & .0 & .00\end{array}$

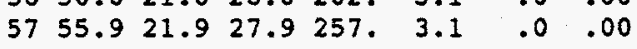

Day Temp. Dew Solar Wind Cloud Precip Max. Min. Pt Rad Speed Cover

$\begin{array}{llllllllll}58 & 59.0 & 23.0 & 29.3 & 322 . & 4.0 & .0 & .00\end{array}$

$\begin{array}{llllllll}59 & 60.1 & 21.9 & 29.7 & 249 . & 4.0 & .0 & .00\end{array}$

$\begin{array}{llllllllll}60 & 59.0 & 25.0 & 27.5 & 323 & 5.4 & .0 & .00\end{array}$

$\begin{array}{llllllllll}61 & 54.0 & 33.1 & 32.5 & 397 . & 4.9 & .0 & .00\end{array}$

$\begin{array}{llllllll}62 & 62.1 & 37.9 & 29.7 & 253 . & 5.6 & .0 & .00\end{array}$

$\begin{array}{llllllllll}63 & 55.9 & 32.0 & 34.7 & 435 & 5.1 & .0 & .00\end{array}$

$\begin{array}{llllllll}64 & 53.1 & 30.9 & 33.4 & 88 . & 4.7 & .0 & .10\end{array}$

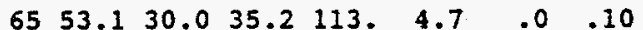

$\begin{array}{llllllll}66 & 43.0 & 33.1 & 35.6 & 379 . & 4.7 & .0 & .10\end{array}$

$\begin{array}{llllllll}67 & 54.0 & 27.0 & 27.5 & 405 . & 11.0 & .0 & .00\end{array}$

$\begin{array}{llllllll}68 & 54.0 & 26.1 & 23.7 & 399 . & 6.9 & .0 & .00\end{array}$

$\begin{array}{lllllllll}69 & 57.0 & 19.9 & 25.3 & 345 . & 4.5 & .0 & .00\end{array}$

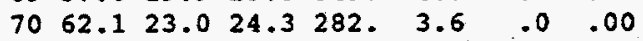

$\begin{array}{llllllllll}71 & 64.9 & 19.0 & 24.8 & 157 . & 3.6 & .0 & .00\end{array}$

$\begin{array}{llllllllll}72 & 64.9 & 19.9 & 24.6 & 465 & 4.0 & .0 & .00\end{array}$

$\begin{array}{lllllllll}73 & 66.0 & 21.9 & 26.6 & 401 . & 4.9 & .0 & .00\end{array}$

$\begin{array}{llllllll}74 & 63.0 & 30.0 & 27.7 & 338 & 5.8 & .0 & .00\end{array}$

$\begin{array}{lllllllllll}75 & 52.0 & 25.0 & 30.9 & 107 . & 6.3 & .0 & .00\end{array}$

$\begin{array}{lllllllllll}76 & 46.9 & 33.1 & 34.3 & 283 & 5.1 & .0 & .00\end{array}$

$\begin{array}{llllllllllll}77 & 46.0 & 30.9 & 31.1 & 485 . & 6.0 & .0 & .00\end{array}$

$\begin{array}{lllllllllll}78 & 53.1 & 24.1 & 26.2 & 307 . & 6.0 & .0 & .00\end{array}$

$\begin{array}{llllllllllll}79 & 57.9 & 26.1 & 19.8 & 202 . & 9.6 & .0 & .00\end{array}$

$\begin{array}{lllllllll}80 & 51.1 & 26.1 & 14.0 & 479 . & 13.4 & .0 & .00\end{array}$

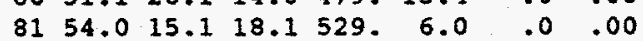

$\begin{array}{lllllllll}82 & 57.0 & 30.9 & 28.0 & 534 . & 4.7 & .0 & .00\end{array}$

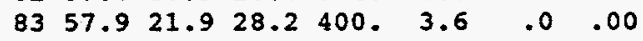

$\begin{array}{lllllllllll}84 & 59.0 & 18.0 & 21.2 & 438, & 3.6 & .0 & .00\end{array}$

$\begin{array}{llllllllll}85 & 57.9 & 23.0 & 26.1 & 271 . & 6.5 & .0 & .00\end{array}$

$\begin{array}{llllllllllll}86 & 57.9 & 36.0 & 33.8 & 436 . & 10.7 & .0 & .00\end{array}$

$\begin{array}{llllllllll}87 & 57.9 & 24.1 & 26.6 & 542 . & 4.3 & .0 & .00\end{array}$

$\begin{array}{lllllllllll}88 & 62.1 & 19.0 & 28.2 & 471 . & 5.6 & .0 & .00\end{array}$

$\begin{array}{lllllllll}89 & 63.0 & 27.0 & 32.5 & 417 . & 4.7 & .0 & .00\end{array}$

$\begin{array}{lllllllll}90 & 62.1 & 23.0 & 22.6 & 337 . & 11.2 & .0 & .00\end{array}$

$\begin{array}{llllllllll}91 & 68.0 & 21.0 & 21.7 & 372 . & 4.3 & .0 & .00\end{array}$

$\begin{array}{llllllllll}92 & 72.0 & 25.0 & 24.8 & 436 . & 5.6 & .0 & .00\end{array}$

$\begin{array}{lllllllllll}93 & 75.0 & 25.0 & 23.2 & 520 . & 8.5 & .0 & .00\end{array}$

$\begin{array}{lllllllll}94 & 66.0 & 37.0 & 25.5 & 550 . & 13.6 & .0 & .00\end{array}$ $95 \quad 51.128 .0 \quad 13.6 \quad 300.17 .9 \quad .0 \quad .00$ $\begin{array}{llllllllll}96 & 50.0 & 19.0 & 7.7 & 385.15 .4 & .0 & .00\end{array}$ $\begin{array}{llllllllll}97 & 57.0 & 9.0 & 12.0 & 249 . & 9.6 & .0 & .00\end{array}$ $\begin{array}{llllllll}98 & 61.0 & 39.0 & 24.8 & 394 . & 16.3 & .0 & .00\end{array}$ $9963.0 \quad 41.0 \quad 33.4 \quad 482.23 .0 \quad .0 \quad .00$ $\begin{array}{llllllll}100 & 60.1 & 41.0 & 34.9 & 584.21 .5 & .0 & .00\end{array}$

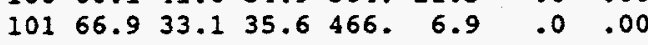
$\begin{array}{lllllllll}102 & 69.1 & 33.1 & 33.3 & 568 . & 6.0 & .0 & .00\end{array}$ $\begin{array}{llllllll}103 & 69.1 & 37.9 & 37.8 & 379.12 .3 & .0 & .00\end{array}$ $\begin{array}{lllllllll}104 & 71.1 & 34.0 & 34.2 & 394.6 & 6.3 & .0 & .00\end{array}$ $\begin{array}{lllllllll}105 & 70.0 & 43.0 & 39.4 & 504 . & 5.4 & .0 & .00\end{array}$ $\begin{array}{lllllllll}106 & 70.0 & 33.1 & 35.8 & 592 & 10.5 & .0 & .00\end{array}$

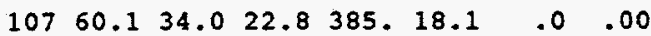
$\begin{array}{lllllll}10857.0 & 33.1 & 23.0 & 512.13 .6 & .0 & .00\end{array}$ $\begin{array}{lllllllll}109 & 57.9 & 23.0 & 21.7 & 620 . & 6.7 & .0 & .00\end{array}$ $11064.921 .022 .8 \quad 620.4 .9 \quad .0 \quad .00$ $\begin{array}{llllllllll}111 & 62.1 & 39.0 & 31.1 & 539 . & 9.8 & .0 & .00\end{array}$ $\begin{array}{llllllll}112 & 51.1 & 30.9 & 32.7 & 483 . & 13.9 & .0 & .00\end{array}$ $\begin{array}{llllllllll}113 & 52.0 & 21.9 & 17.2 & 652 . & 7.2 & .0 & .00\end{array}$

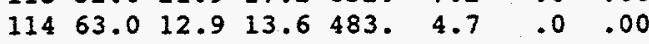
$\begin{array}{llllllll}115 & 73.9 & 21.9 & 17.2 & 683 . & 4.7 & .0 & .00\end{array}$ $\begin{array}{lllllllllll}116 & 82.0 & 27.0 & 22.8 & 658 & 6.5 & .0 & .00\end{array}$ 
Day Temp. Dew Solar wind Cloud Precip Max. Min. Pt Rad Speed Cover

$\begin{array}{lllllll}117 & 78.1 & 41.0 & 23.5 & 649.12 .3 & .0 & .00\end{array}$

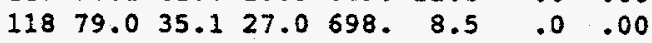

$\begin{array}{llllllll}119 & 86.0 & 33.1 & 28.9 & 451.0 & 9.4 & .0 & .00\end{array}$

$\begin{array}{llllllll}120 & 64.9 & 48.9 & 25.7 & 337 . & 18.6 & .0 & .00\end{array}$

$\begin{array}{llllllllll}121 & 64.9 & 42.1 & 27.1 & 459 & 7.2 & .0 & .00\end{array}$

$\begin{array}{llllllll}122 & 73.0 & 21.9 & 16.5 & 491 . & 5.8 & .0 & .00\end{array}$

$\begin{array}{lllllllllll}123 & 79.0 & 28.9 & 19.2 & 594 . & 4.7 & .0 & .00\end{array}$

$\begin{array}{llllllllllll}124 & 82.9 & 30.0 & 21.0 & 464 & 5.1 & .0 & .00\end{array}$

$\begin{array}{llllllllllll}125 & 84.9 & 32.0 & 21.4 & 674 . & 4.9 & .0 & .00\end{array}$

$\begin{array}{llllllllll}126 & 89.1 & 34.0 & 21.2 & 725 . & 6.3 & .0 & .00\end{array}$

$\begin{array}{llllllllll}127 & 87.1 & 43.0 & 29.1 & 595 . & 5.1 & .0 & .00\end{array}$

$\begin{array}{lllllllllll}128 & 77.0 & 46.0 & 33.1 & 731 . & 10.7 & .0 & .00\end{array}$

$\begin{array}{llllllllll}129 & 57.9 & 30.0 & 32.0 & 734.0 & 9.8 & .0 & .00\end{array}$

$\begin{array}{llllllll}130 & 69.1 & 24.1 & 25.9 & 546.15 .4 & .0 & .00\end{array}$

$\begin{array}{llllllllll}131 & 68.0 & 39.0 & 20.8 & 733.22 .6 & .0 & .00\end{array}$

$\begin{array}{llllllllll}132 & 70.0 & 21.9 & 12.7 & 743 . & 8.9 & .0 & .00\end{array}$

$\begin{array}{lllllllllllll}133 & 80.1 & 39.0 & 23.9 & 601 & 8.5 & .0 & .00\end{array}$

$\begin{array}{lllllllll}134 & 82.9 & 37.0 & 30.6 & 726 . & 8.1 & .0 & .00\end{array}$

$\begin{array}{llllllll}135 & 68.0 & 48.0 & 44.2 & 493 . & 6.3 & .0 & .30\end{array}$

$\begin{array}{lllllllllll}136 & 77.0 & 35.1 & 32.5 & 593 . & 6.3 & .0 & .00\end{array}$

$\begin{array}{llllllll}137 & 84.9 & 37.9 & 32.7 & 543 . & 6.0 & .0 & .00\end{array}$

$\begin{array}{lllllllll}138 & 84.9 & 45.0 & 33.4 & 758 . & 8.9 & .0 & .00\end{array}$

$\begin{array}{lllllllll}139 & 84.9 & 43.0 & 28.8 & 579 . & 9.6 & .0 & .00\end{array}$

$\begin{array}{lllllllll}140 & 73.9 & 50.0 & 37.6 & 666 . & 14.3 & .0 & .00\end{array}$

$\begin{array}{lllllllllll}141 & 68.0 & 44.1 & 34.7 & 765 & 7.6 & .0 & .00\end{array}$

$\begin{array}{llllllll}142 & 79.0 & 36.0 & 36.1 & 767 . & 5.1 & .0 & .00\end{array}$

$\begin{array}{llllllllll}143 & 84.9 & 41.0 & 33.3 & 657 . & 5.4 & .0 & .00\end{array}$

$\begin{array}{lllllllll}144 & 88.0 & 41.0 & 34.0 & 721 . & 5.8 & .0 & .00\end{array}$

$\begin{array}{llllllllll}145 & 87.1 & 52.0 & 38.5 & 538 . & 8.5 & .0 & .00\end{array}$

$\begin{array}{llllllll}146 & 81.0 & 52.0 & 40.6 & 641 . & 11.4 & .0 & .00\end{array}$

$\begin{array}{lllllllll}147 & 75.0 & 46.0 & 33.4 & 553 . & 5.8 & .0 & .00\end{array}$

$\begin{array}{llllllll}148 & 78.1 & 42.1 & 33.6 & 633 & 6.9 & .0 & .00\end{array}$

$\begin{array}{llllllllll}149 & 73.0 & 46.0 & 39.2 & 779 . & 7.6 & .0 & .00\end{array}$

$\begin{array}{lllllllll}150 & 77.0 & 44.1 & 35.8 & 611 . & 8.7 & .0 & .00\end{array}$

$\begin{array}{lllllllll}151 & 77.0 & 50.0 & 32.5 & 726.10 .5 & .0 & .00\end{array}$

$\begin{array}{llllllllll}152 & 84.0 & 39.0 & 30.6 & 709 . & 5.6 & .0 & .00\end{array}$

$\begin{array}{lllllllllll}153 & 84.9 & 46.9 & 39.0 & 657 & 6.0 & .0 & .00\end{array}$

$\begin{array}{llllllllll}154 & 84.0 & 41.0 & 33.1 & 582 . & 8.9 & .0 & .00\end{array}$

$\begin{array}{llllllllll}155 & 82.9 & 39.9 & 20.7 & 525.13 .4 & .0 & .00\end{array}$

$\begin{array}{llllllllll}156 & 72.0 & 43.0 & 30.0 & 590 . & 8.1 & .0 & .00\end{array}$

$\begin{array}{lllllllll}157 & 78.1 & 42.1 & 30.4 & 425 & 6.9 & .0 & .00\end{array}$

$\begin{array}{llllllllll}158 & 84.9 & 39.0 & 27.3 & 681 . & 5.8 & .0 & .00\end{array}$

$\begin{array}{llllllllllll}159 & 86.0 & 45.0 & 31.6 & 595 . & 6.5 & .0 & .00\end{array}$

$\begin{array}{lllllllllll}160 & 88.0 & 42.1 & 33.3 & 475 . & 7.4 & .0 & .00\end{array}$

$\begin{array}{lllllllll}161 & 86.0 & 51.1 & 43.0 & 190 . & 6.0 & .0 & .20\end{array}$

$\begin{array}{llllllll}162 & 84.0 & 54.0 & 46.0 & 645 . & 7.2 & .0 & .00\end{array}$

$\begin{array}{lllllllll}163 & 86.0 & 41.0 & 38.3 & 793.16 .3 & .0 & .00\end{array}$

$\begin{array}{lllllllll}164 & 62.1 & 39.9 & 32.2 & 687 . & 10.5 & .0 & .00\end{array}$

$\begin{array}{llllllll}165 & 69.1 & 42.1 & 38.8 & 692.10 .1 & .0 & .40\end{array}$

$\begin{array}{lllllllll}166 & 63.0 & 48.9 & 44.1 & 438.11 .0 & .0 & .40\end{array}$

$\begin{array}{lllllllll}167 & 59.0 & 46.0 & 48.0 & 529.12 .8 & .0 & .20\end{array}$

$\begin{array}{lllllllllll}168 & 72.0 & 48.0 & 48.9 & 598 . & 4.0 & .0 & .00\end{array}$

$\begin{array}{llllllllll}169 & 82.0 & 51.1 & 45.7 & 612 & 6.5 & .0 & .00\end{array}$

$\begin{array}{lllllllllll}170 & 84.9 & 55.0 & 42.6 & 538 . & 6.9 & .0 & .00\end{array}$

$\begin{array}{lllllllllll}171 & 86.0 & 55.0 & 44.1 & 794 . & 7.2 & .0 & .00\end{array}$

$\begin{array}{lllllllll}172 & 90.0 & 48.9 & 41.4 & 794 . & 4.7 & .0 & .00\end{array}$

$\begin{array}{llllllllll}173 & 93.9 & 53.1 & 44.2 & 692 . & 5.6 & .0 & .00\end{array}$

$\begin{array}{lllllllll}174 & 97.0 & 57.0 & 45.7 & 793 & 6.3 & .0 & .00\end{array}$

$\begin{array}{lllllllllll}175 & 96.1 & 53.1 & 46.4 & 691 . & 7.8 & .0 & .10\end{array}$
Day Temp. Dew Solar Wind Cloud Precip Max. Min. Pt Rad Speed Cover

$\begin{array}{llllllllll}176 & 78.1 & 59.0 & 55.0 & 695 . & 9.6 & .0 & .10\end{array}$

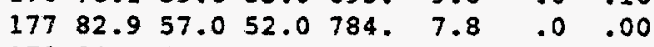

$\begin{array}{llllllll}178 & 84.0 & 55.9 & 54.1 & 791 . & 7.4 & .0 & .00\end{array}$

$\begin{array}{llllllll}179 & 89.1 & 48.0 & 49.6 & 619 & 8.7 & .0 & .00\end{array}$

$\begin{array}{llllllll}180 & 72.0 & 51.1 & 46.2 & 774.11 .6 & .0 & .10\end{array}$

$\begin{array}{lllllllll}181 & 66.9 & 46.9 & 42.3 & 731 . & 12.1 & .0 & .10\end{array}$

$\begin{array}{lllllllll}182 & 69.1 & 37.9 & 41.0 & 764 . & 6.0 & .0 & .00\end{array}$

$\begin{array}{lllllllllll}183 & 73.9 & 50.0 & 43.0 & 611 . & 5.6 & .0 & .00\end{array}$

$\begin{array}{llllllllll}184 & 84.0 & 48.0 & 41.4 & 670 . & 7.4 & .0 & .00\end{array}$

$\begin{array}{llllllll}185 & 90.0 & 57.0 & 41.0 & 540.11 .0 & .0 & .00\end{array}$

$\begin{array}{llllllll}186 & 88.0 & 45.0 & 34.2 & 783 . & 10.3 & .0 & .00\end{array}$

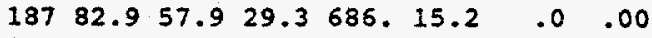

$\begin{array}{llllllllll}188 & 79.0 & 50.0 & 33.4 & 570.16 .6 & .0 & .00\end{array}$

$\begin{array}{llllllll}189 & 82.0 & 43.0 & 29.1 & 638.11 .9 & .0 & .00\end{array}$

$\begin{array}{llllllllll}190 & 79.0 & 39.9 & 35.6 & 709 . & 6.9 & .0 & .00\end{array}$

$\begin{array}{llllllllll}191 & 82.9 & 43.0 & 35.1 & 776 . & 8.5 & .0 & .00\end{array}$

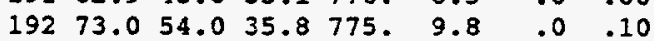

$\begin{array}{llllllll}193 & 73.9 & 53.1 & 35.8 & 670 . & 5.4 & .0 & .10\end{array}$

$\begin{array}{llllllll}194 & 86.0 & 45.0 & 35.8 & 760 . & 8.9 & .0 & .00\end{array}$

$\begin{array}{lllllllll}195 & 89.1 & 52.0 & 35.8 & 714 . & 16.3 & .0 & .00\end{array}$

$\begin{array}{llllllll}196 & 86.0 & 45.0 & 35.8 & 767 . & 5.8 & .0 & .00\end{array}$

$\begin{array}{lllllllll}197 & 87.1 & 53.1 & 35.8 & 709 . & 7.2 & .0 & .00\end{array}$

$\begin{array}{llllllll}198 & 91.9 & 48.9 & 36.7 & 458 & 6.0 & .0 & .00\end{array}$

$\begin{array}{llllllllll}199 & 91.0 & 50.0 & 39.0 & 589 . & 8.1 & .0 & .00\end{array}$

$\begin{array}{lllllllll}200 & 88.0 & 57.0 & 45.0 & 653 . & 9.2 & .0 & .00\end{array}$

$\begin{array}{lllllllll}201 & 88.0 & 45.0 & 48.4 & 512.11 .4 & .0 & .00\end{array}$

$\begin{array}{llllllll}202 & 81.0 & 46.9 & 46.2 & 701 . & 8.5 & .0 & .00\end{array}$

$\begin{array}{llllllll}203 & 88.0 & 48.9 & 43.9 & 611 . & 7.6 & .0 & .00\end{array}$

$\begin{array}{llllllll}204 & 80.1 & 53.1 & 31.5 & 634.13 .2 & .0 & .00\end{array}$

$\begin{array}{llllllll}205 & 84.0 & 48.9 & 28.8 & 747 . & 8.7 & .0 & .00\end{array}$

$\begin{array}{llllllll}206 & 86.0 & 43.0 & 29.1 & 670 . & 6.9 & .0 & .00\end{array}$

$\begin{array}{lllllllllll}207 & 93.0 & 43.0 & 29.7 & 493 . & 5.6 & .0 & .00\end{array}$

$\begin{array}{llllllllll}208 & 95.0 & 46.9 & 31.5 & 560 . & 6.3 & .0 & .00\end{array}$

$\begin{array}{lllllllllll}209 & 93.9 & 50.0 & 38.7 & 715 & 6.0 & .0 & .00\end{array}$

$\begin{array}{llllllll}210 & 91.9 & 45.0 & 31.5 & 605 . & 5.4 & .0 & .00\end{array}$

$\begin{array}{llllllll}211 & 93.0 & 52.0 & 36.7 & 730 . & 6.3 & .0 & .00\end{array}$

$\begin{array}{lllllllll}212 & 95.0 & 48.9 & 35.6 & 727 & 6.5 & .0 & .00\end{array}$

$\begin{array}{lllllll}213100.0 & 52.0 & 36.5 & 657 . & 6.0 & .0 & .00\end{array}$

$214100.948 .936 .7665 .8 .1 \quad .0 \quad .00$

$\begin{array}{llllllll}215 & 96.1 & 59.0 & 36.5 & 626.11 .2 & .0 & .00\end{array}$

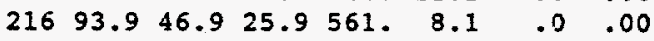

$\begin{array}{llllllll}217 & 93.0 & 51.1 & 25.7 & 465.11 .9 & .0 & .00\end{array}$

$\begin{array}{lllllllll}218 & 91.0 & 48.0 & 34.3 & 537 . & 13.2 & .0 & .00\end{array}$

$\begin{array}{lllllllll}219 & 91.9 & 51.1 & 33.6 & 549.14 .5 & .0 & .00\end{array}$

$\begin{array}{llllllll}220 & 89.1 & 55.9 & 39.0 & 459.15 .0 & .0 & .00\end{array}$

$\begin{array}{lllllllll}221 & 91.9 & 53.1 & 35.8 & 434.11 .6 & .0 & .00\end{array}$

$\begin{array}{llllllll}222 & 98.1 & 45.0 & 31.6 & 433 . & 5.4 & .0 & .00\end{array}$

$22397.050 .034 .3465,6.9 \quad .0 \quad .00$

$\begin{array}{llllllllll}224 & 99.0 & 55.0 & 32.9 & 448 . & 6.9 & .0 & .00\end{array}$

$\begin{array}{llllllll}225 & 99.0 & 53.1 & 33.6 & 453 . & 5.6 & .0 & .00\end{array}$

$\begin{array}{llllllll}226 & 98.1 & 53.1 & 36.5 & 651 . & 4.7 & .0 & .00\end{array}$

$\begin{array}{llllllll}227 & 84.9 & 53.1 & 44.1 & 588 . & 6.9 & .0 & .00\end{array}$

$\begin{array}{llllllll}228 & 88.0 & 57.0 & 50.5 & 670 & 5.6 & .0 & .00\end{array}$

$\begin{array}{llllllllll}229 & 89.1 & 57.9 & 50.5 & 666 . & 6.9 & .0 & .00\end{array}$

$\begin{array}{llllllllll}230 & 93.0 & 48.0 & 44.6 & 612 & 5.4 & .0 & .00\end{array}$

$\begin{array}{llllllll}231 & 96.1 & 48.9 & 42.4 & 471 . & 7.2 & .0 & .00\end{array}$

$\begin{array}{llllllll}232 & 91.9 & 46.0 & 44.1 & 611 . & 7.6 & .0 & .00\end{array}$

$\begin{array}{lllllllll}233 & 90.0 & 51.1 & 37.4 & 537 . & 9.2 & .0 & .00\end{array}$

$\begin{array}{llllllllll}234 & 75.9 & 57.0 & 27.9 & 645 . & 17.7 & .0 & .00\end{array}$ 


\begin{tabular}{|c|c|c|c|c|c|c|c|}
\hline Day & $\begin{array}{r}\text { Te } \\
\text { Max. }\end{array}$ & Min. & $\begin{array}{c}\text { Dew } s \\
\text { Pt }\end{array}$ & $\begin{array}{l}\text { Solar } \\
\text { Rad }\end{array}$ & $\begin{array}{l}\text { Wind } \\
\text { Speed }\end{array}$ & $\begin{array}{l}\text { Cloud } \\
\text { Cover }\end{array}$ & Precl \\
\hline 235 & 68.0 & 42.1 & 27.0 & 543 & 12.8 & .0 & .00 \\
\hline 236 & 69.1 & 30.9 & 7.3 & 406 . & 6.3 & .0 & .00 \\
\hline 237 & 68.0 & 26.1 & 19.0 & 632. & .7 & .0 & .00 \\
\hline 238 & 75.9 & 24.1 & 9.1 & 608 & 6.0 & .0 & .00 \\
\hline 239 & 86.0 & 30.0 & 13.6 & 456 & 7.8 & .0 & .00 \\
\hline 240 & 87.1 & 50.0 & 22.3 & 618. & 15.9 & .0 & .00 \\
\hline 241 & 82.9 & 39.9 & 25.3 & 614. & 7.2 & .0 & .00 \\
\hline 242 & 86.0 & 37.0 & 27.7 & 573 & 7.6 & .0 & .00 \\
\hline 243 & 69.1 & 46.9 & 49.6 & 357. & 6.0 & .0 & .10 \\
\hline 244 & 79.0 & 37.9 & 45.1 & 473 & 6.0 & .0 & .10 \\
\hline 245 & 82.9 & 39.9 & 36.3 & 545. & 9.6 & .0 & .00 \\
\hline 246 & 84.0 & 45.0 & 39.9 & 491. & 7.6 & .0 & .20 \\
\hline 247 & 68.0 & 48.9 & 47.1 & 492. & 10.3 & .0 & .10 \\
\hline 248 & 68.0 & 37.9 & 37.4 & 430. & 13.9 & .0 & .10 \\
\hline 249 & 63.0 & 43.0 & 37.9 & 398. & 13.2 & .0 & .10 \\
\hline 250 & 64.0 & 28.0 & 24.1 & 381. & 4.9 & .0 & .00 \\
\hline 251 & 75.9 & 39.9 & 26.6 & 433. & 13.2 & .0 & .00 \\
\hline 252 & 75.9 & 35.1 & 32.0 & 490. & 5.4 & .0 & .00 \\
\hline 253 & 82.0 & 34.0 & 28.9 & 446. & 4.7 & .0 & .00 \\
\hline 254 & 79.0 & 48.9 & 34.3 & 464. & 5.6 & .0 & .00 \\
\hline 255 & 71.1 & 43.0 & 34.0 & 521. & 14.8 & .0 & .00 \\
\hline 256 & 62.1 & 34.0 & 14.2 & 349. & 17.2 & .0 & .00 \\
\hline 257 & 72.0 & 21.9 & 15.6 & 536. & 4.9 & .0 & .00 \\
\hline 258 & 77.0 & 32.0 & 18.5 & 451. & 10.3 & .0 & .00 \\
\hline 259 & 80.1 & 39.0 & 21.7 & 244. & 13.4 & .0 & .00 \\
\hline 260 & 80.1 & 43.0 & 25.2 & 444. & 13.4 & .0 & .00 \\
\hline 261 & 79.0 & 30.9 & 24.3 & 455. & 5.4 & .0 & .00 \\
\hline 262 & 75.0 & 32.0 & 24.6 & 384 . & 8.1 & .0 & .00 \\
\hline 263 & 78.1 & 36.0 & 32.7 & 495. & 10.3 & .0 & .00 \\
\hline 264 & 80.1 & 39.9 & 39.6 & 501. & 4.9 & .0 & .00 \\
\hline 265 & 88.0 & 37.0 & 35.1 & 446. & 6.3 & .0 & .00 \\
\hline 266 & 86.0 & 45.0 & 37.6 & 393. & 9.6 & .0 & .00 \\
\hline 267 & 70.0 & 43.0 & 31.8 & 485 & 17.7 & .0 & .00 \\
\hline 268 & 64.9 & 37.0 & 26.2 & 480. & 9.2 & .0 & .00 \\
\hline 269 & 68.0 & 24.1 & 23.7 & 475 . & $7 \cdot 4$ & .0 & .00 \\
\hline 270 & 77.0 & 30.0 & 22.5 & 425 & 7.2 & .0 & .00 \\
\hline 271 & 81.0 & 24.1 & 19.0 & 465. & 5.1 & .0 & .00 \\
\hline 272 & 86.0 & 28.9 & 21.7 & 368 & 4.0 & .0 & .00 \\
\hline 273 & 88.0 & 28.9 & 21.9 & 199. & 4.7 & .0 & .00 \\
\hline 274 & 87.1 & 36.0 & 22.6 & 298. & 4.9 & .0 & .00 \\
\hline 275 & 84.0 & 43.0 & 26.2 & 239. & 9.2 & .0 & .00 \\
\hline 276 & 57.9 & 44.1 & 42.4 & 200. & 11.9 & .0 & .20 \\
\hline 277 & 59.0 & 37.9 & 43.2 & 324 . & 6.9 & .0 & .00 \\
\hline 278 & 63.0 & 36.0 & 39.2 & 412 . & 3.6 & .0 & .00 \\
\hline 279 & 57.9 & 30.0 & 27.1 & 418. & 8.1 & .0 & .00 \\
\hline 280 & 57.9 & 18.0 & 19.0 & 419. & 4.5 & .0 & .00 \\
\hline 281 & 55.0 & 32.0 & 20.5 & 366 & 4.0 & .0 & .00 \\
\hline 282 & 64.0 & 28.9 & 25.9 & 208 . & 7.2 & .0 & .00 \\
\hline 283 & 68.0 & 28.0 & 28.4 & 163. & 4.0 & .0 & .00 \\
\hline 284 & 73.9 & 26.1 & 29.5 & 267 . & $4 \cdot 5$ & .0 & .00 \\
\hline 285 & 78.1 & 30.9 & 26.8 & 325 . & $11 \cdot 2$ & .0 & .00 \\
\hline 286 & 70.0 & 37.9 & 26.6 & 364 & 15.7 & .0 & .00 \\
\hline 287 & 57.0 & 23.0 & 18.0 & 377 . & 11.2 & .0 & .00 \\
\hline 288 & 52.0 & 19.0 & 10.2 & 222 & 6.5 & .0 & .00 \\
\hline 289 & 62.1 & 23.0 & 10.0 & 241 & 7.2 & .0 & .00 \\
\hline 290 & 64.9 & 30.0 & 20.7 & 317 & 6.9 & .0 & .00 \\
\hline 291 & 66.0 & 23.0 & 22.6 & 235 & 4.9 & .0 & .00 \\
\hline 292 & 71.1 & 27.0 & 24.1 & 363. & 4.9 & .0 & .00 \\
\hline 293 & 75.9 & 23.0 & 24.1 & 357. & 4.7 & .0 & .00 \\
\hline
\end{tabular}

Day Temp. Dew Solar wind Cloud Precip Max. Min. Pt Rad Speed Cover

$\begin{array}{llllllllll}294 & 73.9 & 27.0 & 27.1 & 340 . & 8.7 & .0 & .00\end{array}$

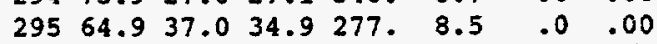

$\begin{array}{lllllllll}296 & 66.0 & 19.9 & 24.6 & 287 . & 5.4 & .0 & .00\end{array}$

$\begin{array}{lllllllll}297 & 75.0 & 25.0 & 26.4 & 287 & 5.6 & .0 & .00\end{array}$

$\begin{array}{llllllll}298 & 73.0 & 30.0 & 29.8 & 111 . & 4.9 & .0 & .00\end{array}$

$\begin{array}{llllllllll}299 & 68.0 & 28.9 & 36.0 & 173 . & 7.4 & .0 & .00\end{array}$

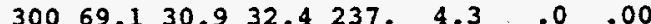

$\begin{array}{llllllll}301 & 64.0 & 33.1 & 35.6 & 65 . & 5.1 & .0 & .10\end{array}$

$\begin{array}{llllllll}302 & 48.9 & 39.9 & 43.3 & 114 . & 10.1 & .0 & .10\end{array}$

$\begin{array}{llllllll}303 & 51.1 & 34.0 & 37.6 & 185.12 .3 & .0 & .00\end{array}$

$\begin{array}{lllllllll}304 & 50.0 & 27.0 & 29.8 & 252 . & 8.5 & .0 & .00\end{array}$

$\begin{array}{llllllllll}305 & 48.9 & 33.1 & 35.8 & 242 . & 11.2 & .0 & .00\end{array}$

$\begin{array}{llllllll}306 & 46.9 & 30.0 & 3.4 & 221 & 12.3 & .0 & .00\end{array}$

$\begin{array}{llllllll}307 & 43.0 & 14.0 & 17.2 & 153 . & 6.9 & .0 & .00\end{array}$

$\begin{array}{lllllllllll}308 & 35.1 & 9.0 & 19.6 & 264 . & 4.0 & .0 & .00\end{array}$

$\begin{array}{lllllllll}309 & 42.1 & 19.9 & 28.0 & 294 . & 7.4 & .0 & .00\end{array}$

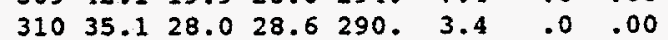

$\begin{array}{llllllll}311 & 51.1 & 27.0 & 30.9 & 287 . & 5.4 & .0 & .00\end{array}$

$\begin{array}{lllllll}312 & 37.0 & 28.9 & 28.9 & 183.13 .6 & .0 & .00\end{array}$

$\begin{array}{lllllllllll}313 & 39.9 & 17.1 & 24.8 & 280.10 .3 & .0 & .00\end{array}$

$\begin{array}{llllllllll}314 & 35.1 & 6.1 & 17.8 & 220 & 6.3 & .0 & .00\end{array}$

$\begin{array}{llllllllll}315 & 32.0 & 18.0 & 19.6 & 274 . & 4.3 & .0 & .00\end{array}$

$\begin{array}{llllllllll}316 & 33.1 & 18.0 & 20.7 & 271 . & 2.5 & .0 & .00\end{array}$

$\begin{array}{lllllllll}317 & 33.1 & 19.9 & 24.4 & 268 . & 3.6 & .0 & .00\end{array}$

$\begin{array}{lllllllllll}318 & 46.0 & 19.0 & 26.2 & 225 & 4.0 & .0 & .00\end{array}$

$\begin{array}{lllllllll}319 & 48.9 & 14.0 & 24.1 & 256 . & 4.0 & .0 & .00\end{array}$

$\begin{array}{llllllll}320 & 50.0 & 16.0 & 23.7 & 156 . & 3.6 & .0 & .00\end{array}$

$\begin{array}{lllllllllll}321 & 46.9 & 21.9 & 27.9 & 236 . & 3.6 & .0 & .00\end{array}$

$\begin{array}{llllllll}322 & 37.0 & 32.0 & 32.0 & 58 . & 3.8 & .0 & .00\end{array}$

$\begin{array}{lllllllll}323 & 37.0 & 30.0 & 30.4 & 204 . & 4.0 & .0 & .00\end{array}$

$\begin{array}{lllllllll}324 & 37.9 & 17.1 & 19.2 & 153 & 13.2 & .0 & .00\end{array}$

$\begin{array}{llllllll}325 & 27.0 & 12.0 & 17.1 & 246 . & 3.4 & .0 & .00\end{array}$

$\begin{array}{llllllll}326 & 33.1 & 3.0 & 20.8 & 112 . & 4.3 & .0 & .00\end{array}$

$\begin{array}{lllllllll}327 & 32.0 & -2.9 & 11.5 & 168 . & 5.8 & .0 & .00\end{array}$

$\begin{array}{lllllll}328 & 25.0-11.9 & -3.1 & 86 . & 3.6 & .0 & .00\end{array}$

$\begin{array}{lllllll}329 & 21.0-16.1 & -7.2 & 120 . & 4.3 & .0 & .00\end{array}$

$33021.0-17.0 \quad-5.8155 .4 .5 \quad .0 \quad .00$

$\begin{array}{lllllll}331 & 21.9-15.0 & 1.2 & 188 . & 3.6 & .0 & .00\end{array}$

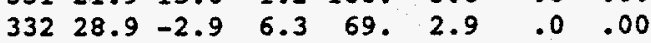

$\begin{array}{lllllllll}333 & 17.1 & -6.0 & 4.8 & 108 . & 3.4 & .0 & .00\end{array}$

$\begin{array}{lllllllll}334 & 28.0 & 12.9 & 16.7 & 160 . & 3.4 & .0 & .00\end{array}$

$\begin{array}{llllllllll}335 & 21.9 & 1.9 & 13.8 & 155 . & 6.0 & .0 & .00\end{array}$

$\begin{array}{lllllllll}336 & 30.9 & 19.0 & 23.7 & 45 . & 3.4 & .0 & .00\end{array}$

$\begin{array}{lllllll}337 & 26.1-16.1 & 5.4 & 224 & 9.4 & .0 & .00\end{array}$

$\begin{array}{llllll}338 & 6.1-27.9-18.4 & 208 . & 4.9 & .0 & .00\end{array}$

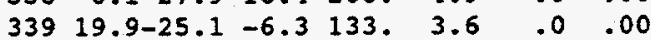

$\begin{array}{lllllll}340 & 15.1-16.1 & -4.2 & 123 . & 4.7 & .0 & .00\end{array}$

$\begin{array}{lllllll}341 & 24.1-15.0 & 7.7 & 86 . & 5.6 & .0 & .00\end{array}$

$\begin{array}{llllllll}342 & 35.1 & 24.1 & 27.9 & 71 . & 11.9 & .0 & .00\end{array}$

$\begin{array}{llllllllllll}343 & 35.1 & 26.1 & 28.6 & 217 . & 17.7 & .0 & .00\end{array}$

$\begin{array}{llllllllll}344 & 28.9 & 12.0 & 19.0 & 204 . & 2.9 & .0 & .00\end{array}$

$\begin{array}{lllllllll}345 & 36.0 & 14.0 & 27.9 & 48 . & 10.1 & .0 & .00\end{array}$

$\begin{array}{llllllllll}346 & 30.9 & -9.9 & 8.4 & 168 . & 7.4 & .0 & .00\end{array}$

$\begin{array}{lllllllll}347 & 24.1-13.0 & 2.3 & 136 . & 7.4 & .0 & .00\end{array}$

$\begin{array}{lllllllll}348 & 15.1 & 5.0 & 9.1 & 130 . & 7.4 & .0 & .00\end{array}$

$\begin{array}{llllllll}349 & 28.0-11.0 & 4.1 & 190 . & 4.7 & .0 & .00\end{array}$

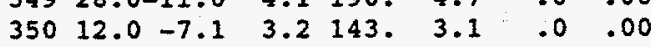

$\begin{array}{lllllllll}351 & 17.1 & 7.0 & 12.0 & 142 . & 5.6 & .0 & .00\end{array}$

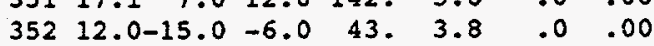


Day Temp. Dew Solar wind Cloud Precip Max. Min. Pt Rad Speed Cover

$\begin{array}{rrrrrrrr}353 & 10.9 & -6.0 & -.9 & 213 . & 2.9 & .0 & .00 \\ 354 & 17.1 & 1.0 & 8.2 & 213 . & 3.1 & .0 & .00 \\ 355 & 30.0 & 10.9 & 17.4 & 164 . & 8.3 & .0 & .00 \\ 356 & 27.0 & 9.0 & 20.3 & 124 . & 19.9 & .0 & .00 \\ 357 & 33.1 & 18.0 & 23.2 & 185 . & 9.8 & .0 & .00 \\ 358 & 30.0 & 10.0 & 18.7 & 198 . & 4.7 & .0 & .00 \\ 359 & 21.9 & -.9 & 13.1 & 215 . & 1.6 & .0 & .00 \\ 360 & 19.0 & -2.9 & 4.8 & 189 . & 1.6 & .0 & .00 \\ 361 & 35.1 & 6.1 & 21.2 & 216 . & 10.5 & .0 & .00 \\ 362 & 33.1 & 3.9 & 14.7 & 217 . & 4.3 & .0 & .00 \\ 363 & 34.0 & 26.1 & 30.0 & 53 . & 9.6 & .0 & .00 \\ 364 & 26.1 & 10.0 & 17.6 & 164 . & 11.2 & .0 & .00 \\ 365 & 18.0-11.0 & 6.1 & 63 . & 4.9 & .0 & .00\end{array}$

Year 1993

Day Temp. Dew Solar wind Cloud Precip Max. Min. Pt Rad Speed Cover

$\begin{array}{lllllllllll}1 & 30.9 & 17.1 & 23.7 & 170 . & 5.1 & .0 & .00\end{array}$

$\begin{array}{llllllll}2 & 30.9 & -2.9 & 10.0 & 177 . & 13.0 & .0 & .00\end{array}$

$\begin{array}{llllllll} & 6.1 & -9.9 & -5.1 & 222 . & 1.8 & .0 & .00\end{array}$

$412.9-20.0-5.1103 .2 .9 \quad .0 \quad .00$

$59.0-18.0-17.3148 .2 .7 \quad .0 \quad .00$

$6 \quad 6.1-14.1-9.4 \quad 143,3.8 \quad .0 \quad .00$

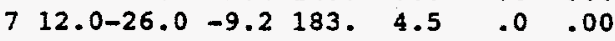

$\begin{array}{lllllllll}8 & 23.0 & 10.9 & 16.0 & 46 . & 4.5 & .0 & .00\end{array}$

$\begin{array}{llllllll}9 & 19.0 & -5.1 & 8.4 & 196 . & 8.3 & .0 & .00\end{array}$

$\begin{array}{llllllll}10 & 21.0 & .0 & 9.1 & 138 . & 4.3 & .0 & .00\end{array}$

$\begin{array}{llllllll}11 & 24.1 & 10.9 & 15.1 & 47 . & 18.1 & .0 & .00\end{array}$

$\begin{array}{lllllll}12 & 15.1-18.0 & -.9 & 153 . & 4.9 & .0 & .00\end{array}$

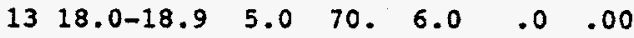

$\begin{array}{llllllll}14 & 28.0 & 17.1 & 23.7 & 60 . & 4.0 & .0 & .00\end{array}$

$\begin{array}{llllllll}15 & 30.0 & 10.0 & 21.2 & 189 . & 9.6 & .0 & .00\end{array}$

$\begin{array}{llllllll}16 & 30.9 & 17.1 & 22.6 & 49 . & 3.1 & .0 & .00\end{array}$

$\begin{array}{lllllllll}17 & 27.0 & -2.9 & 13.3 & 98 . & 5.6 & .0 & .00\end{array}$

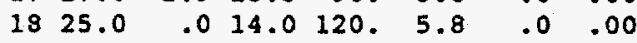

$\begin{array}{llllllllll}19 & 30.0 & 7.0 & 18.7 & 151 . & 8.3 & .0 & .00\end{array}$

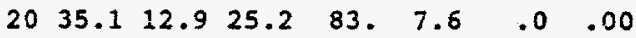

$\begin{array}{llllllll}21 & 34.0 & 21.0 & 24.6 & 75 . & 14.1 & .0 & .00\end{array}$

$\begin{array}{llllllll}22 & 35.1 & 14.0 & 26.6 & 52 . & 17.9 & .0 & .00\end{array}$

$\begin{array}{llllllll}23 & 17.1 & -2.9 & 2.1 & 193 . & 4.9 & .0 & .00\end{array}$

$\begin{array}{lllllllll}24 & 18.0 & -9.0 & 3.2 & 144 . & 3.8 & .0 & .00\end{array}$

$\begin{array}{llllllllll}25 & 21.0 & -2.9 & 7.9 & 234 . & 3.8 & .0 & .00\end{array}$

$\begin{array}{llllllll}26 & 19.9 & -5.1 & .9 & 232 . & 1.6 & .0 & .00\end{array}$

$\begin{array}{lllllll}27 & 19.0-11.9 & -2.7 & 276 . & 1.8 & .0 & .00\end{array}$

$\begin{array}{llllllll}28 & 23.0 & -8.0 & 5.4 & 279 . & 2.5 & .0 & .00\end{array}$

$\begin{array}{llllllll}29 & 21.0 & -6.0 & 5.5 & 256 . & 2.7 & .0 & .00\end{array}$

$\begin{array}{lllllll}30 & 16.0-11.9 & -3.6 & 162 . & 2.9 & .0 & .00\end{array}$

$\begin{array}{lllllll}31 & 23.0-11.0 & .7 & 128 . & 3.4 & .0 & .00\end{array}$

$\begin{array}{lllllllll}32 & 16.0 & -8.0 & -.2 & 197 . & 4.0 & .0 & .00\end{array}$

$\begin{array}{llllllll}33 & 19.9 & -9.0 & -.8 & 226 . & 3.4 & .0 & .00\end{array}$

$\begin{array}{lllllll}34 & 12.9-14.1 & -5.8 & 214 . & 2.7 & .0 & .00\end{array}$

$\begin{array}{lllllll}35 & 25.0-11.9 & -4.7 & 172 . & 2.5 & .0 & .00\end{array}$

$\begin{array}{lllllll}36 & 21.0-14.1 & -3.8 & 213 . & 3.1 & .0 & .00\end{array}$

$\begin{array}{lllllllll}37 & 25.0 & -9.9 & 10.0 & 273 . & 2.9 & .0 & .00\end{array}$

$\begin{array}{llllllll}38 & 33.1 & 3.9 & 18.1 & 315 & 3.1 & .0 & .00\end{array}$

$\begin{array}{llllllll}39 & 28.9 & .0 & 7.0 & 238 . & 3.6 & .0 & .00\end{array}$

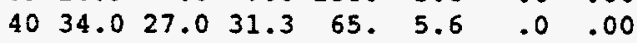

Day Temp. Dew Solar wind Cloud Precip Max. Min. Pt Rad Speed Cover

$\begin{array}{llllllllll}41 & 32.0 & 28.0 & 31.1 & 122 . & 5.8 & .0 & .00\end{array}$

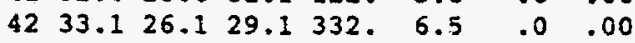

$4328.017 .122 .3 \quad 310.14 .1 \quad .0 \quad .00$

$\begin{array}{llllllll}44 & 24.1 & 12.0 & 17.1 & 256 . & 2.7 & .0 & .00\end{array}$

$\begin{array}{lllllllll}45 & 25.0 & 6.1 & 14.0 & 327 . & 4.3 & .0 & .00\end{array}$

$\begin{array}{lllllllll}46 & 15.1 & 5.0 & 10.4 & 168.13 .0 & .0 & .00\end{array}$

$\begin{array}{lllllll}47 & 7.0-24.0 & -8.7 & 203.10 .1 & .0 & .00\end{array}$

$48 \quad 10.0-27.0-24.5246 .3 .1 \quad .0 \quad .00$

$\begin{array}{llllllll}49 & 24.1 & 9.0 & 17.2 & 135 . & 5.6 & .0 & .00\end{array}$

$\begin{array}{llllllll}50 & 37.0 & 23.0 & 30.4 & 178 . & 7.8 & .0 & .00\end{array}$

$\begin{array}{llllllll}51 & 33.1 & 10.9 & 25.0 & 74 . & 22.4 & .0 & .00\end{array}$

$\begin{array}{llllllll}52 & 21.9 & 12.9 & 18.7 & 376 . & 19.5 & .0 & .00\end{array}$

$\begin{array}{lllllllll}53 & 21.9 & 3.0 & 11.1 & 198 . & 11.6 & .0 & .00\end{array}$

$\begin{array}{llllllllll}54 & 21.0 & .0 & 12.6 & 112 & 7.4 & .0 & .00\end{array}$

$\begin{array}{llllllllllll}55 & 26.1 & 10.0 & 18.3 & 143 & 5.4 & .0 & .00\end{array}$

$\begin{array}{lllllllll}56 & 25.0 & 1.0 & 12.9 & 202 . & 5.4 & .0 & .00\end{array}$

$\begin{array}{lllllll}57 & 12.9-16.1 & -5.8 & 257 . & 5.4 & .0 & .00\end{array}$

58 10.9-23.1-13.9 322. $5.4 \quad .0 \quad .00$

$\begin{array}{lllllll}59 & 21.0-22.0 & -8.0 & 249 . & 5.4 & .0 & .00\end{array}$

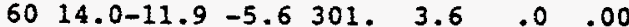

$\begin{array}{llllllllll}61 & 19.0 & -9.9 & -3.1 & 323 . & 4.0 & .0 & .00\end{array}$

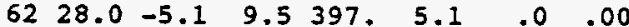

$\begin{array}{llllllll}63 & 21.9 & -2.9 & 9.7 & 253 . & 4.0 & .0 & .00\end{array}$

$\begin{array}{lllllllll}64 & 30.9 & 9.0 & 19.0 & 435 . & 4.0 & .0 & .00\end{array}$

$\begin{array}{lllllllll}65 & 30.0 & 21.9 & 25.2 & 205 . & 4.9 & .0 & .00\end{array}$

$\begin{array}{llllllll}66 & 34.0 & 21.9 & 27.5 & 272 & 3.6 & .0 & .00\end{array}$

$\begin{array}{llllllllll}67 & 35.1 & 27.0 & 29.1 & 451 . & 3.1 & .0 & .00\end{array}$

$\begin{array}{lllllllllll}68 & 35.1 & 27.0 & 29.7 & 405 . & 5.8 & .0 & .00\end{array}$

$\begin{array}{lllllllll}69 & 34.0 & 23.0 & 25.7 & 399 . & 4.7 & .0 & .00\end{array}$

$\begin{array}{llllllll}70 & 30.0 & 12.0 & 16.9 & 345 . & 6.3 & .0 & .00\end{array}$

$\begin{array}{llllllllll}71 & 19.9 & -.9 & 7.0 & 282 . & 6.0 & .0 & .00\end{array}$

$\begin{array}{llllllll}72 & 32.0 & 9.0 & 12.6 & 157 . & 5.1 & .0 & .00\end{array}$

$\begin{array}{llllllllllll}73 & 33.1 & 10.0 & 21.4 & 465 . & 4.0 & .0 & .00\end{array}$

$\begin{array}{llllllll}74 & 39.9 & 19.0 & 30.2 & 401.23 .0 & .0 & .00\end{array}$

$\begin{array}{llllllllll}75 & 39.0 & 30.9 & 32.4 & 338 & 12.5 & .0 & .18\end{array}$

$\begin{array}{llllllll}76 & 41.0 & 32.0 & 33.4 & 99 . & 3.6 & .0 & .37\end{array}$

$\begin{array}{llllllllllll}77 & 42.1 & 28.9 & 33.6 & 283 & 5.8 & .0 & .21\end{array}$

$\begin{array}{lllllllll}78 & 41.0 & 28.0 & 30.0 & 485 . & 4.7 & .0 & .15\end{array}$

$\begin{array}{llllllll}79 & 42.1 & 26.1 & 29.8 & 307 . & 9.2 & .0 & .13\end{array}$

$\begin{array}{lllllllll}80 & 41.0 & 24.1 & 24.8 & 202 . & 5.4 & .0 & .03\end{array}$

$\begin{array}{llllllll}81 & 41.0 & 15.1 & 23.0 & 479 . & 4.9 & .0 & .00\end{array}$

$\begin{array}{lllllllllll}82 & 46.0 & 15.1 & 25.7 & 529 . & 4.3 & .0 & .00\end{array}$

$\begin{array}{llllllll}83 & 43.0 & 24.1 & 32.0 & 434 . & 5.4 & .0 & .19\end{array}$

$\begin{array}{lllllllll}84 & 45.0 & 34.0 & 37.4 & 245 . & 6.9 & .0 & .75\end{array}$

$\begin{array}{llllllll}85 & 51.1 & 33.1 & 39.0 & 296 . & 7.2 & .0 & .71\end{array}$

$\begin{array}{lllllllll}86 & 52.0 & 30.0 & 36.3 & 271 . & 6.0 & .0 & .54\end{array}$

$\begin{array}{lllllllllll}87 & 51.1 & 35.1 & 38.7 & 436 . & 6.7 & .0 & .67\end{array}$

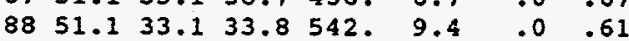

$\begin{array}{llllllllll}89 & 52.0 & 30.0 & 28.9 & 471.05 & 5.8 & 0 & .07\end{array}$

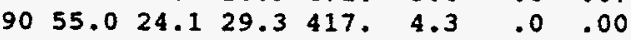

$\begin{array}{lllllllll}91 & 53.1 & 28.0 & 31.8 & 337 . & 11.2 & .0 & .00\end{array}$

$\begin{array}{llllllll}92 & 48.9 & 30.9 & 32.0 & 184 . & 7.6 & .0 & .20\end{array}$

$\begin{array}{lllllllll}93 & 48.9 & 27.0 & 33.4 & 436 . & 3.8 & .0 & .00\end{array}$

$\begin{array}{llllllllllll}94 & 48.0 & 34.0 & 38.7 & 396 . & 10.3 & .0 & .20\end{array}$

$\begin{array}{lllllllll}95 & 50.0 & 30.9 & 29.8 & 550.12 .1 & .0 & .00\end{array}$

$\begin{array}{llllllll}96 & 48.9 & 26.1 & 23.5 & 300 . & 4.5 & .0 & .00\end{array}$

$9755.919 .924 .8 \quad 385.05 .4 \quad .0 \quad .00$

$\begin{array}{llllllll}98 & 59.0 & 28.9 & 30.6 & 249 . & 8.5 & .0 & .00\end{array}$

$9952.0 \quad 30.931 .6394 .17 .7 \quad .0 \quad .00$ 
Day

Temp. Dew Solar wind Cloud Precip Max. Min. Pt Rad Speed Cover

$\begin{array}{lllllllll}100 & 48.9 & 23.0 & 29.5 & 326 . & 11.2 & .0 & .10\end{array}$

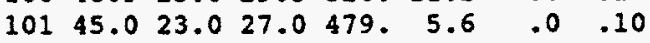

$\begin{array}{llllllll}102 & 45.0 & 23.0 & 29.3 & 297 . & 4.7 & .0 & .20\end{array}$

$\begin{array}{llllllll}103 & 52.0 & 18.0 & 24.4 & 568 . & 5.6 & .0 & .00\end{array}$

$\begin{array}{lllllllll}104 & 51.1 & 23.0 & 25.9 & 379 . & 7.8 & .0 & .00\end{array}$

$\begin{array}{llllllll}105 & 55.0 & 19.9 & 30.2 & 394 . & 8.3 & .0 & .00\end{array}$

$\begin{array}{lllllllll}106 & 59.0 & 33.1 & 28.8 & 504 . & 8.7 & .0 & .00\end{array}$

$\begin{array}{llllllll}107 & 60.1 & 36.0 & 30.7 & 592 . & 11.4 & .0 & .00\end{array}$

$\begin{array}{lllllllll}108 & 50.0 & 32.0 & 30.0 & 155 . & 17.2 & .0 & .10\end{array}$

$\begin{array}{llllllll}109 & 54.0 & 25.0 & 20.8 & 512 . & 6.7 & .0 & .00\end{array}$

$\begin{array}{lllllllll}110 & 57.0 & 19.9 & 22.8 & 620 & 6.3 & .0 & .00\end{array}$

$\begin{array}{lllllllll}111 & 68.0 & 28.9 & 22.6 & 620.11 .6 & .0 & .00\end{array}$

$\begin{array}{llllllll}112 & 53.1 & 39.9 & 36.9 & 385 . & 10.5 & .0 & .10\end{array}$

$\begin{array}{llllllllll}113 & 55.9 & 33.1 & 27.7 & 483 & 14.1 & .0 & .00\end{array}$

$\begin{array}{llllllll}114 & 53.1 & 34.0 & 34.7 & 560 & 8.9 & .0 & .10\end{array}$

$\begin{array}{lllllllll}115 & 55.9 & 30.0 & 32.5 & 483 & 7.4 & .0 & .00\end{array}$

$\begin{array}{llllllll}116 & 57.9 & 33.1 & 29.8 & 607 . & 14.5 & .0 & .20\end{array}$

$\begin{array}{llllllll}117 & 57.0 & 21.0 & 22.6 & 564 . & 6.3 & .0 & .10\end{array}$

$\begin{array}{llllllll}118 & 64.0 & 24.1 & 24.1 & 649 . & 8.7 & .0 & .00\end{array}$

$\begin{array}{llllllllll}119 & 57.9 & 36.0 & 34.2 & 698.11 .2 & .0 & .00\end{array}$

$\begin{array}{llllllll}120 & 54.0 & 30.0 & 34.5 & 451 . & 6.7 & .0 & .00\end{array}$

$\begin{array}{lllllllll}121 & 62.1 & 28.9 & 29.7 & 337 . & 7.8 & .0 & .00\end{array}$

$\begin{array}{llllllll}122 & 56.9 & 44.1 & 34.0 & 459 . & 14.3 & .0 & .00\end{array}$

$\begin{array}{llllllll}123 & 62.1 & 33.1 & 39.2 & 279 & 9.6 & .0 & 50\end{array}$

$\begin{array}{lllllllll}124 & 46.0 & 34.0 & 36.3 & 446 . & 8.3 & .0 & .40\end{array}$

$\begin{array}{lllllllll}125 & 48.9 & 35.1 & 41.2 & 229 & 9.6 & .0 & .10\end{array}$

$\begin{array}{lllllllll}126 & 46.0 & 37.0 & 41.7 & 573 . & 6.7 & .0 & .30\end{array}$

$\begin{array}{llllllll}127 & 53.1 & 34.0 & 35.4 & 690 . & 12.8 & .0 & .30\end{array}$

$\begin{array}{lllllllll}128 & 50.0 & 28.9 & 31.8 & 439 & 5.6 & .0 & .10\end{array}$

$\begin{array}{lllllllllll}129 & 60.1 & 25.0 & 30.6 & 731 . & 5.6 & .0 & .00\end{array}$

$\begin{array}{lllllllllll}130 & 72.0 & 32.0 & 35.4 & 734 . & 8.3 & .0 & .00\end{array}$

$\begin{array}{lllllllll}131 & 79.0 & 37.9 & 36.1 & 546 . & 8.3 & .0 & .00\end{array}$

$\begin{array}{llllllll}132 & 79.0 & 39.9 & 35.4 & 733 . & 8.7 & 0 & 00\end{array}$

$\begin{array}{lllllllllll}133 & 81.0 & 46.0 & 42.8743 . & 5.8 & .0 & .00\end{array}$

$13475.943 .0 \quad 44.8601 .7 .4 .00 .00$

$\begin{array}{llllllllll}135 & 78.1 & 44.1 & 46.4 & 645 & 6.3 & .0 & .10\end{array}$

$\begin{array}{llllllllll}136 & 73.9 & 44.1 & 47.1 & 493 & 6.3 & .0 & .20\end{array}$

$\begin{array}{lllllllll}137 & 75.9 & 37.9 & 45.0 & 593 . & 4.5 & .0 & .00\end{array}$

$\begin{array}{lllllllll}138 & 79.0 & 42.1 & 42.1 & 543 . & 8.1 & .0 & .00\end{array}$

$\begin{array}{lllllllll}139 & 80.1 & 46.9 & 46.6 & 758 . & 5.8 & .0 & .00\end{array}$

$\begin{array}{llllllll}140 & 82.0 & 46.9 & 46.4 & 579 . & 9.4 & .0 & .00\end{array}$

$\begin{array}{llllllll}141 & 70.0 & 51.1 & 45.5 & 533 . & 11.2 & .0 & .10\end{array}$

$\begin{array}{lllllllll}142 & 63.0 & 41.0 & 39.9 & 765 & 7.2 & .0 & .00\end{array}$

$\begin{array}{lllllllll}143 & 66.9 & 41.0 & 37.0 & 767 & 8.3 & .0 & .00\end{array}$

$\begin{array}{llllllll}14472.0 & 43.0 & 37.9 & 657, & 9.2 & .0 & .00\end{array}$

$\begin{array}{lllllllll}145 & 80.1 & 46.0 & 37.9 & 721 . & 10.3 & .0 & .00\end{array}$

$\begin{array}{llllllll}146 & 78.1 & 46.0 & 41.4 & 538 . & 8.5 & .0 & .00\end{array}$

$\begin{array}{lllllllll}147 & 78.1 & 45.0 & 38.8 & 641 . & 9.8 & .0 & .00\end{array}$

$\begin{array}{lllllllll}148 & 79.0 & 45.0 & 37.6 & 553 . & 9.8 & .0 & .00\end{array}$

$\begin{array}{llllllll}149 & 73.0 & 46.9 & 36.0 & 633 & 11.4 & .0 & .00\end{array}$

$\begin{array}{llllllll}150 & 77.0 & 34.0 & 35.8 & 779 . & 5.6 & .0 & .00\end{array}$

$\begin{array}{lllllllll}15179.0 & 51.1 & 39.9 & 611 & 12.3 & .0 & .00\end{array}$

$\begin{array}{lllllll}152 & 70.0 & 45.0 & 38.5 & 726.17 .0 & .0 & .00\end{array}$

$\begin{array}{llllllllll}153 & 66.0 & 34.0 & 39.6 & 590.10 .3 & .0 & .20\end{array}$

$\begin{array}{lllllllll}154 & 53.1 & 43.0 & 45.7 & 500 & 6.9 & .0 & .30\end{array}$

$\begin{array}{lllllllll}155 & 57.9 & 36.0 & 43.5 & 582 . & 5.6 & .0 & .00\end{array}$

$\begin{array}{llllllll}156 & 52.0 & 46.9 & 49.5 & 266.10 .1 & .0 & .80\end{array}$

$\begin{array}{lllllllll}157 & 55.0 & 43.0 & 46.0 & 379 . & 10.5 & .0 & .80\end{array}$

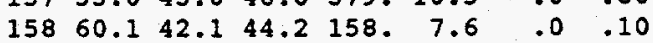

Day Temp: Dew Solar wind Cloud Precip Max. Min. Pt Rad Speed Cover

$\begin{array}{lllllllllll}159 & 61.0 & 41.0 & 43.0 & 537 . & 9.8 & .0 & .10\end{array}$

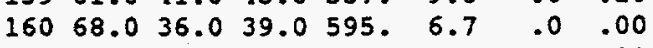

$\begin{array}{lllllllll}161 & 69.1 & 41.0 & 45.0 & 174 . & 8.5 & .0 & .10\end{array}$

$\begin{array}{lllllllll}162 & 68.0 & 39.9 & 39.2 & 485 & 12.8 & .0 & .00\end{array}$

$\begin{array}{lllllllll}163 & 59.0 & 32.0 & 31.6 & 645.11 .4 & .0 & .00\end{array}$

$\begin{array}{lllllllllll}164 & 68.0 & 28.9 & 32.5 & 793 . & 4.7 & .0 & .00\end{array}$

$\begin{array}{lllllllll}165 & 79.0 & 35.1 & 40.1 & 687.6 .3 & .0 & .00\end{array}$

$\begin{array}{llllllll}166 & 75.9 & 48.9 & 44.4 & 692 . & 11.4 & .0 & .10\end{array}$

$\begin{array}{llllllllll}167 & 68.0 & 37.9 & 43.2 & 438 . & 7.2 & .0 & .10\end{array}$

$\begin{array}{lllllllll}168 & 68.0 & 46.0 & 40.8 & 680.15 .2 & .0 & .00\end{array}$

$\begin{array}{llllllllllll}169 & 75.9 & 36.0 & 38.1 & 598 . & 6.5 & .0 & .00\end{array}$

$\begin{array}{llllllllll}170 & 82.0 & 43.0 & 45.1 & 612 . & 6.0 & .0 & .00\end{array}$

$\begin{array}{llllllll}171 & 86.0 & 45.0 & 47.1 & 538 . & 5.8 & .0 & .00\end{array}$

$\begin{array}{llllllll}172 & 77.0 & 43.0 & 48.4 & 788 . & 8.9 & .0 & .10\end{array}$

$\begin{array}{lllllllll}173 & 63.0 & 45.0 & 38.7 & 794.19 .5 & .0 & .00\end{array}$

$\begin{array}{lllllllll}174 & 61.0 & 37.0 & 27.9 & 692 . & 8.7 & .0 & .00\end{array}$

$\begin{array}{llllllll}175 & 71.1 & 34.0 & 34.5 & 793 & 8.5 & .0 & .00\end{array}$

$\begin{array}{llllllll}176 & 78.1 & 35.1 & 40.6 & 771 . & 5.8 & .0 & .00\end{array}$

$\begin{array}{llllllll}177 & 87.1 & 39.9 & 43.9 & 773 & 6.5 & .0 & .00\end{array}$

$\begin{array}{lllllllll}178 & 84.9 & 46.9 & 46.4 & 784 . & 9.4 & .0 & .00\end{array}$

$\begin{array}{llllllll}179 & 79.0 & 53.1 & 48.7 & 791.8 & 8.5 & .0 & .00\end{array}$

$\begin{array}{lllllllllll}180 & 68.0 & 44.1 & 40.1 & 619 & 8.7 & .0 & .00\end{array}$

$\begin{array}{llllllll}181 & 73.9 & 32.0 & 31.6 & 790 . & 9.2 & .0 & .00\end{array}$

$\begin{array}{lllllllll}182 & 78.1 & 36.0 & 34.2 & 789 . & 9.6 & .0 & .00\end{array}$

$\begin{array}{lllllllll}183 & 78.1 & 37.9 & 39.4 & 764.12 .1 & .0 & .00\end{array}$

$\begin{array}{llllllll}184 & 66.9 & 43.0 & 40.1 & 611.11 .6 & .0 & .00\end{array}$

$\begin{array}{lllllllll}185 & 69.1 & 45.0 & 41.9 & 518 . & 6.3 & .0 & .10\end{array}$

$\begin{array}{lllllllllll}186 & 72.0 & 42.1 & 40.5 & 540 . & 6.7 & .0 & .00\end{array}$

$\begin{array}{lllllllll}187 & 73.9 & 35.1 & 37.4 & 783 & 6.7 & .0 & .00\end{array}$

$\begin{array}{lllllll}188 & 73.9 & 34.0 & 33.8 & 686.11 .9 & .0 & .00\end{array}$

$\begin{array}{lllllllll}189 & 73.9 & 44.1 & 37.2 & 570 . & 8.7 & .0 & .00\end{array}$

$\begin{array}{lllllllll}190 & 82.9 & 33.1 & 36.0 & 638 . & 9.4 & .0 & .00\end{array}$

$\begin{array}{llllllll}191 & 80.1 & 43.0 & 34.2 & 709 . & 12.1 & .0 & .00\end{array}$

$\begin{array}{llllllll}192 & 82.9 & 37.9 & 34.2 & 776 . & 9.6 & .0 & .00\end{array}$

$\begin{array}{lllllllll}193 & 75.0 & 48.0 & 34.2 & 775.18 .8 & .0 & .00\end{array}$

$194 \quad 79.0 \quad 32.0 \quad 34.2 \quad 753.6 .7 \quad .0 \quad .00$

$\begin{array}{lllllllll}195 & 75.9 & 35.1 & 34.2 & 760.13 .2 & .0 & .00\end{array}$

$\begin{array}{lllllllll}196 & 73.9 & 52.0 & 32.4 & 714.9 .8 & .0 & .00\end{array}$

$19773.0 \quad 46.9 \quad 34.9767 .11 .6 \quad .0 \quad .00$

$\begin{array}{llllllll}198 & 77.0 & 36.0 & 36.0 & 709.11 .2 & .0 & .00\end{array}$

$\begin{array}{llllllllll}199 & 78.1 & 28.9 & 36.0 & 458 & 5.8 & .0 & .00\end{array}$

$\begin{array}{llllllllll}200 & 87.1 & 39.9 & 36.0 & 589 . & 7.6 & .0 & .00\end{array}$

$\begin{array}{llllllllll}201 & 77.0 & 48.0 & 37.2 & 653.14 .3 & .0 & .00\end{array}$

$\begin{array}{lllllllll}202 & 72.0 & 53.1 & 42.3 & 512 . & 9.2 & .0 & .00\end{array}$

$\begin{array}{lllllllll}203 & 64.0 & 41.0 & 42.8 & 701 . & 7.6 & .0 & .00\end{array}$

$20455.942 .148 .4611 .5 .6 \quad .0 \quad .00$

$\begin{array}{llllllllll}205 & 68.0 & 48.9 & 46.0 & 634 . & 10.3 & .0 & .00\end{array}$

$20675.0 \quad 46.0 \quad 41.5 \quad 747.88 .9 \quad .0 \quad .00$

$\begin{array}{lllllllll}207 & 71.1 & 46.0 & 45.0 & 670 & 9.8 & .0 & .00\end{array}$

$\begin{array}{lllllllllll}208 & 79.0 & 37.9 & 46.0 & 493 . & 4.9 & .0 & .00\end{array}$

$\begin{array}{llllllll}209 & 91.0 & 42.1 & 46.0 & 560 . & 8.1 & .0 & .00\end{array}$

$\begin{array}{llllllllll}210 & 84.0 & 50.0 & 47.1 & 715 . & 9.2 & .0 & .00\end{array}$

$\begin{array}{llllllll}211 & 84.9 & 54.0 & 36.7 & 605.14 .5 & .0 & .00\end{array}$

$\begin{array}{llllllllll}21286.0 & 44.1 & 36.7 & 730.7 .4 & .0 & .00\end{array}$

$\begin{array}{llllllll}213 & 87.1 & 42.1 & 39.4 & 727 . & 6.9 & .0 & .00\end{array}$

$\begin{array}{llllllll}214 & 84.9 & 44.1 & 40.6 & 657 . & 9.6 & .0 & .00\end{array}$

$21584.0 \quad 54.0 \quad 39.6 \quad 665.10 .5 \quad .0 \quad .00$

$\begin{array}{llllllll}216 & 84.0 & 48.9 & 48.2 & 626 . & 7.8 & .0 & .00\end{array}$

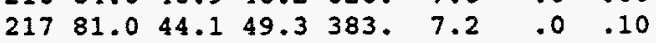


Day Temp. Dew Solar wind Cloud Precip

Max. Min. Pt Rad Speed Cover

$\begin{array}{llllllllll}218 & 84.9 & 48.0 & 47.1 & 465 . & 7.8 & .0 & .00\end{array}$

$\begin{array}{llllllllll}219 & 79.0 & 48.9 & 48.4 & 537 . & 9.2 & .0 & .00\end{array}$

$\begin{array}{lllllllll}220 & 82.9 & 39.9 & 37.0 & 549 . & 9.8 & .0 & .00\end{array}$

$\begin{array}{lllllllll}221 & 90.0 & 43.0 & 37.2 & 459 . & 9.6 & .0 & .00\end{array}$

$\begin{array}{lllllllll}222 & 88.0 & 52.0 & 43.3 & 187 . & 8.5 & .0 & .10\end{array}$

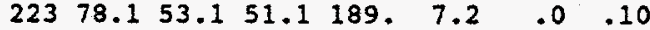

$\begin{array}{lllllllll}224 & 81.0 & 48.0 & 45.9 & 465 . & 8.9 & .0 & .00\end{array}$

$\begin{array}{llllllllll}225 & 79.0 & 46.0 & 44.2 & 448 . & 9.6 & .0 & .00\end{array}$

$\begin{array}{llllllllll}226 & 82.0 & 37.9 & 44.4 & 453 . & 7.2 & .0 & .00\end{array}$

$\begin{array}{llllllll}227 & 80.1 & 42.1 & 41.9 & 651 & 10.1 & .0 & .00\end{array}$

$\begin{array}{lllllll}228 & 66.9 & 46.9 & 43.9 & 454.11 .9 & .0 & .20\end{array}$

$\begin{array}{llllllll}229 & 75.0 & 37.9 & 39.9 & 670 . & 6.5 & .0 & .00\end{array}$

$\begin{array}{llllllllll}230 & 82.0 & 37.0 & 39.4 & 666 . & 6.3 & .0 & .00\end{array}$

$\begin{array}{lllllll}231 & 88.0 & 52.0 & 43.5 & 612.11 .0 & .0 & .00\end{array}$

$\begin{array}{lllllllll}232 & 81.0 & 55.9 & 48.0 & 471 . & 10.7 & .0 & .00\end{array}$

$\begin{array}{llllllll}233 & 72.0 & 48.0 & 50.7 & 501 . & 9.8 & .0 & .20\end{array}$

$\begin{array}{llllllllll}234 & 75.9 & 43.0 & 44.2 & 537 . & 6.0 & .0 & .00\end{array}$

$\begin{array}{llllllllll}235 & 86.0 & 43.0 & 40.1 & 645 . & 9.4 & .0 & .00\end{array}$

$\begin{array}{lllllllll}236 & 75.9 & 48.9 & 38.1 & 543 . & 16.6 & .0 & .00\end{array}$

$\begin{array}{lllllllllll}237 & 70.0 & 45.0 & 27.1 & 406 . & 6.9 & .0 & .00\end{array}$

$\begin{array}{lllllllllll}238 & 73.0 & 36.0 & 26.1 & 632 . & 6.3 & .0 & .00\end{array}$

$\begin{array}{llllllllll}239 & 79.0 & 28.9 & 26.6 & 608 . & 9.6 & .0 & .00\end{array}$

$\begin{array}{llllllll}240 & 81.0 & 35.1 & 27.9 & 456 . & 13.0 & .0 & .00\end{array}$

$24166.9 \quad 42.1 \quad 29.5 \quad 618.9 .2 \quad .0 \quad .00$

$\begin{array}{llllllllll}242 & 72.0 & 34.0 & 22.8 & 614 . & 7.6 & .0 & .00\end{array}$

$\begin{array}{llllllll}24381.0 & 26.1 & 20.1 & 573 & 9.4 & .0 & .00\end{array}$ 
Appendix B

UNSAT-H Simulation Input Data Decks 


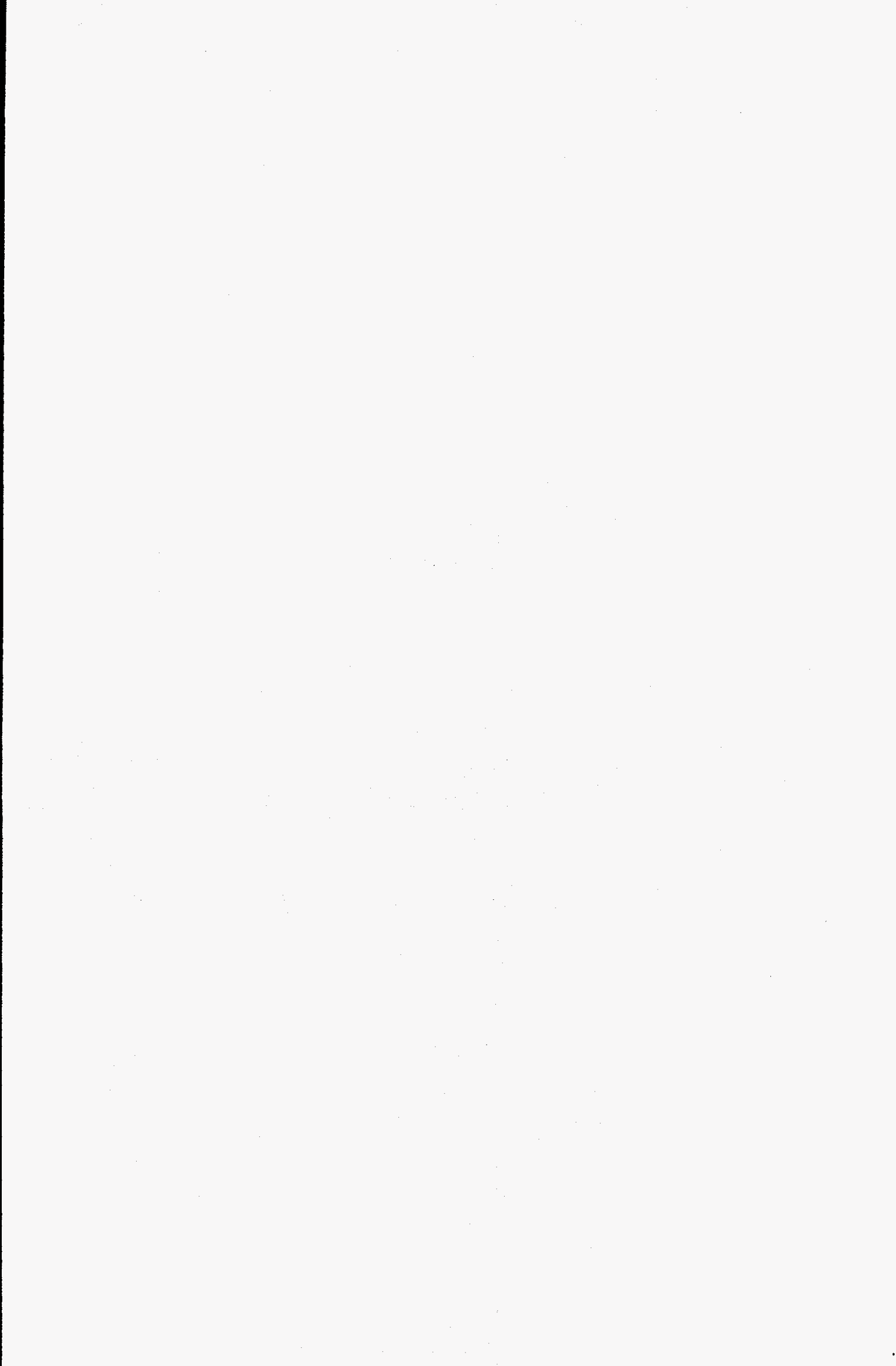




\section{UNSAT-H Simulation Input Data Decks}

This appendix contains the calibrated UNSAT-H input data decks for the NAT W02 and W06 simulation. It includes the ISNOW parameter set to 1 for the modification, which sets the potential evapotranspiration to zero during the winter periods as discussed in Section 4.2.5. The meteorological data set for the input deck are not included for brevity. The base meteorologic data for the period 1985 to 1990 can be found in Magnuson (1993), and data for 1991 to 1993 along with the water application amounts and dates for the increased spring snowmelt are attached in Appendix $A$.

\section{B.1 NAT W02 Input Deck}

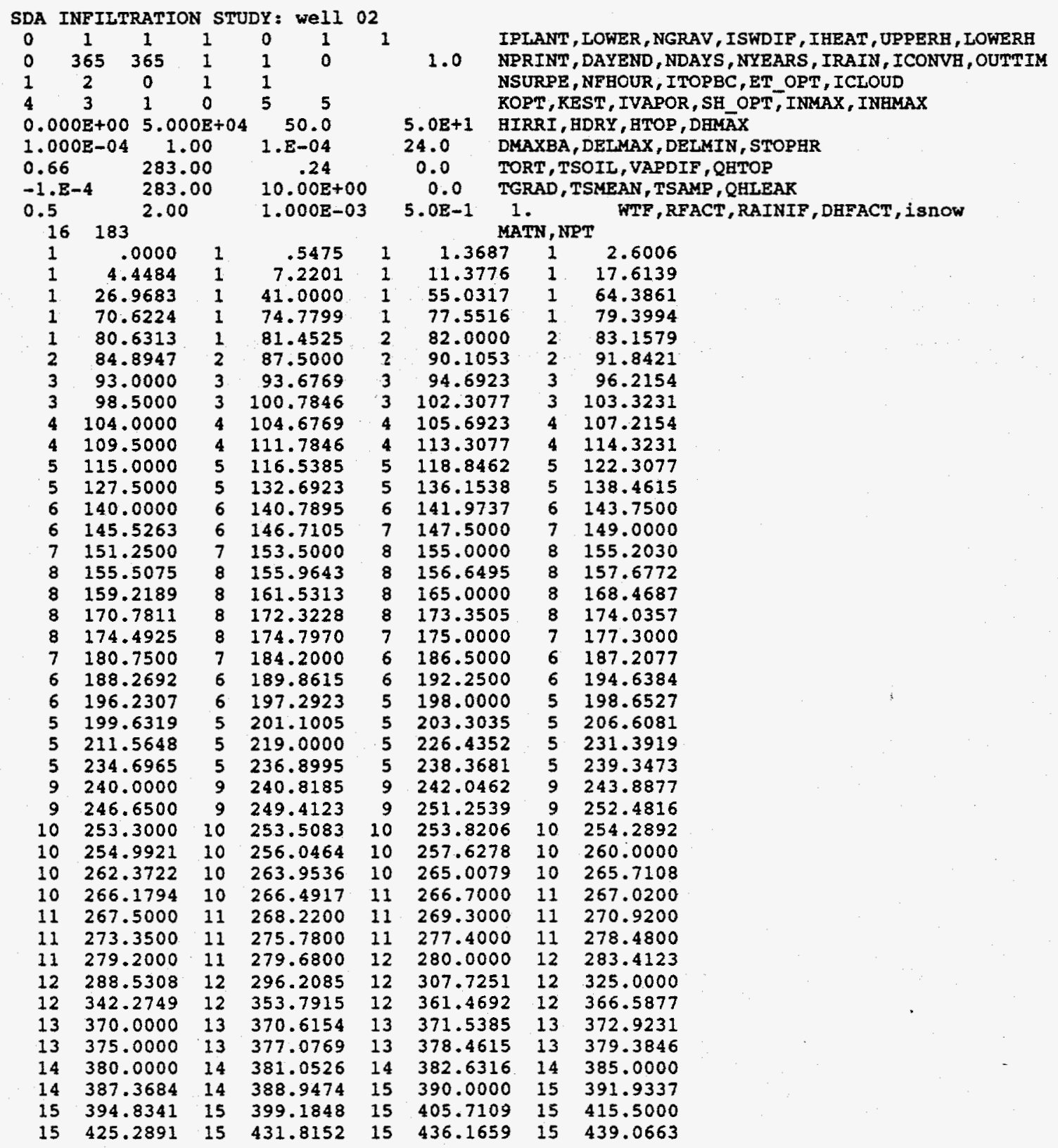




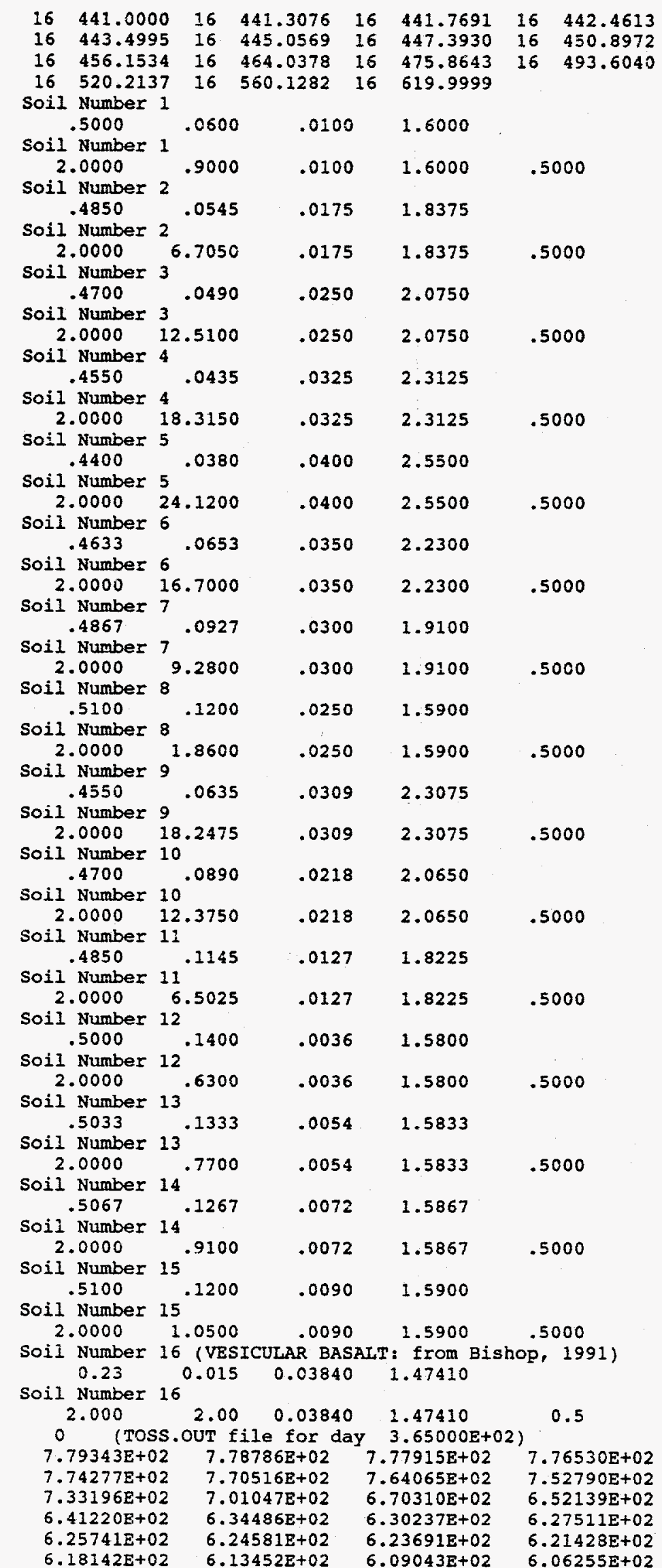

NDAY (UNSAT-H V2.01) Head Values 


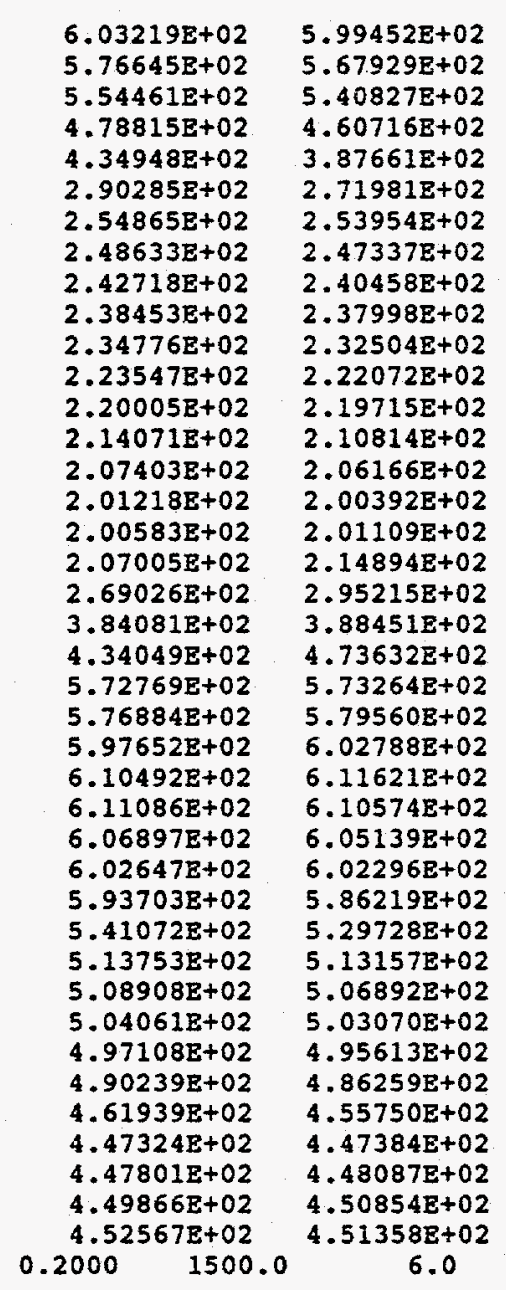

$\begin{array}{ll}5.94086 \mathrm{E}+02 & 5.86630 \mathrm{E}+02 \\ 5.62741 \mathrm{E}+02 & 5.59533 \mathrm{E}+02 \\ 5.23528 \mathrm{E}+02 & 5.02650 \mathrm{E}+02 \\ 4.50813 \mathrm{E}+02 & 4.44949 \mathrm{E}+02 \\ 3.50126 \mathrm{E}+02 & 3.18328 \mathrm{E}+02 \\ 2.62559 \mathrm{E}+02 & 2.57093 \mathrm{E}+02 \\ 2.52602 \mathrm{E}+02 & 2.50601 \mathrm{E}+02 \\ 2.46516 \mathrm{E}+02 & 2.44992 \mathrm{E}+02 \\ 2.38959 \mathrm{E}+02 & 2.38756 \mathrm{E}+02 \\ 2.37317 \mathrm{E}+02 & 2.36299 \mathrm{E}+02 \\ 2.29122 \mathrm{E}+02 & 2.25768 \mathrm{E}+02 \\ 2.21092 \mathrm{E}+02 & 2.20439 \mathrm{E}+02 \\ 2.19522 \mathrm{E}+02 & 2.17338 \mathrm{E}+02 \\ 2.08776 \mathrm{E}+02 & 2.08227 \mathrm{E}+02 \\ 2.04312 \mathrm{E}+02 & 2.02456 \mathrm{E}+02 \\ 2.00065 \mathrm{E}+02 & 2.00264 \mathrm{E}+02 \\ 2.02014 \mathrm{E}+02 & 2.03671 \mathrm{E}+02 \\ 2.29342 \mathrm{E}+02 & 2.47327 \mathrm{E}+02 \\ 3.27795 \mathrm{E}+02 & 3.71586 \mathrm{E}+02 \\ 3.95692 \mathrm{E}+02 & 4.08478 \mathrm{E}+02 \\ 5.16836 \mathrm{E}+02 & 5.63122 \mathrm{E}+02 \\ 5.74012 \mathrm{E}+02 & 5.75148 \mathrm{E}+02 \\ 5.83745 \mathrm{E}+02 & 5.90432 \mathrm{E}+02 \\ 6.06365 \mathrm{E}+02 & 6.08821 \mathrm{E}+02 \\ 6.11654 \mathrm{~B}+02 & 6.11427 \mathrm{E}+02 \\ 6.09803 \mathrm{E}+02 & 6.08644 \mathrm{E}+02 \\ 6.03961 \mathrm{E}+02 & 6.03173 \mathrm{E}+02 \\ 6.02003 \mathrm{E}+02 & 5.98685 \mathrm{E}+02 \\ 5.74970 \mathrm{E}+02 & 5.58048 \mathrm{E}+02 \\ 5.22153 \mathrm{E}+02 & 5.17098 \mathrm{E}+02 \\ 5.12263 \mathrm{E}+02 & 5.10921 \mathrm{E}+02 \\ 5.05548 \mathrm{E}+02 & 5.04651 \mathrm{E}+02 \\ 5.01582 \mathrm{E}+02 & 4.99347 \mathrm{E}+02 \\ 4.94635 \mathrm{E}+02 & 4.92880 \mathrm{E}+02 \\ 4.80248 \mathrm{E}+02 & 4.71144 \mathrm{E}+02 \\ 4.51601 \mathrm{E}+02 & 4.48827 \mathrm{E}+02 \\ 4.47473 \mathrm{E}+02 & 4.47606 \mathrm{E}+02 \\ 4.48500 \mathrm{E}+02 & 4.49080 \mathrm{E}+02 \\ 4.51923 \mathrm{E}+02 & 4.52704 \mathrm{E}+02 \\ 4.50354 \mathrm{E}+02 & \\ 845.0 & \\ & \end{array}$

\section{B.2 NAT W06 Input Deck}

\begin{tabular}{|c|c|c|c|c|c|c|c|c|c|}
\hline 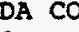 & VER E & BAI & & 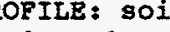 & & er & wo & $\mathrm{BA}$ & \\
\hline 0 & 1 & 1 & 1 & 1 & 1 & & IPLANT & LOWER , NGRAV, ISWDIF , IHEAT, UPPERH, LO & WWERH \\
\hline 0 & 65 & 365 & 1 & 0 & & 1.0 & NPRINT & DAYEND, NDAYS , NYEARS, IRAIN, ICONVH, O & JUTTIM \\
\hline 1 & 2 & 0 & 1 & 1 & & & NSURPE & NFHOUR, ITOPBC, ET_OPT, ICLOUD & \\
\hline 4 & 3 & 1 & 0 & 5 & & & ROPT, K & EST, IVAPOR, SH_OPT, INMAX, INHMAX & \\
\hline 0.000 & $\mathrm{E}+00$ & 2.50 & $O E+04$ & 50.0 & & $5.0 E+1$ & HIRRI, & HDRY, HTOP, DHMĀX & \\
\hline 1.000 & E-04 & 1. & & $1 . E-04$ & & 24.0 & DMAXBA & DELMAX, DELMIN, STOPHR & \\
\hline 0.66 & & 283. & & .24 & & 0.0 & TORT, T & SOIL, VAPDIF, QHTOP & \\
\hline$-1 . E-$ & & 283. & & $10.00 \mathrm{E}+00$ & & 0.0 & TGRAD, & ESMEAN, TSAMP, QHLEAK & \\
\hline 0.5 & & 2.00 & & $1.000 \mathrm{E}-03$ & & $5.0 \mathrm{E}-1$ & 1. & WTF, RFACT, RAINIF, DHFACT, isnow & \\
\hline 12 & 123 & & & & & & MATN, N & & \\
\hline 1 & & 0000 & 1 & .0583 & 1 & .1456 & 1 & .2767 & \\
\hline 1 & & 4733 & 1 & .7682 & 1 & 1.2106 & 1 & 1.8741 & \\
\hline 1 & & 8695 & 1 & 4.3625 & 1 & 6.6019 & 1 & 9.9612 & \\
\hline 1 & 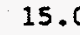 & 0000 & 1 & 20.0388 & 1 & 23.3981 & 1 & 25.6375 & \\
\hline 1 & 27.1 & 1305 & 1 & 28.1259 & 1 & 28.7894 & 1 & 29.2318 & \\
\hline 1 & 29.5 & 5267 & 1 & 29.7233 & 1 & 29.8544 & 1 & 29.9417 & \\
\hline 2 & 30.0 & 0000 & 2 & 31.4032 & 2 & 33.5079 & 2 & 36.6650 & \\
\hline 2 & 39.8 & 8221 & 2 & 41.9268 & 3 & 43.3300 & 3 & 44.7332 & \\
\hline 3 & 46.8 & 8379 & 3 & 49.9950 & 3 & 53.1521 & 3 & 55.2568 & \\
\hline 4 & 56. & 6600 & 4 & 58.0642 & 4 & 60.1705 & 4 & 63.3300 & \\
\hline 4 & 66. & 4895 & 4 & 68.5958 & 5 & 70.0000 & 5 & 70.7218 & \\
\hline 5 & 71.8 & 8045 & 5 & 73.4286 & 5 & 75.8647 & 5 & 79.5188 & \\
\hline 5 & 85. & 0000 & 5 & 90.4812 & 5 & 94.1353 & 5 & 96.5714 & \\
\hline 5 & 98.1 & 1955 & 5 & 99.2782 & 6 & 100.0000 & 6 & 101.0526 & \\
\hline 6 & 102. & 6316 & 6 & 105.0000 & 6 & 107.3684 & 6 & 108.9474 & \\
\hline 7 & 110. & 0000 & 7 & 111.0526 & 7 & 112.6316 & 7 & 115.0000 & - \\
\hline 7 & 117. & 3684 & 7 & 118.9474 & 8 & 120.0000 & 8 & 120.7105 & \\
\hline 8 & 121. & 7764 & 8 & 123.3751 & 8 & 125.7732 & 8 & 129.3703 & \\
\hline 8 & 134. & 7661 & 8 & 142.8596 & 8 & 155.0000 & 8 & 167.1404 & \\
\hline
\end{tabular}




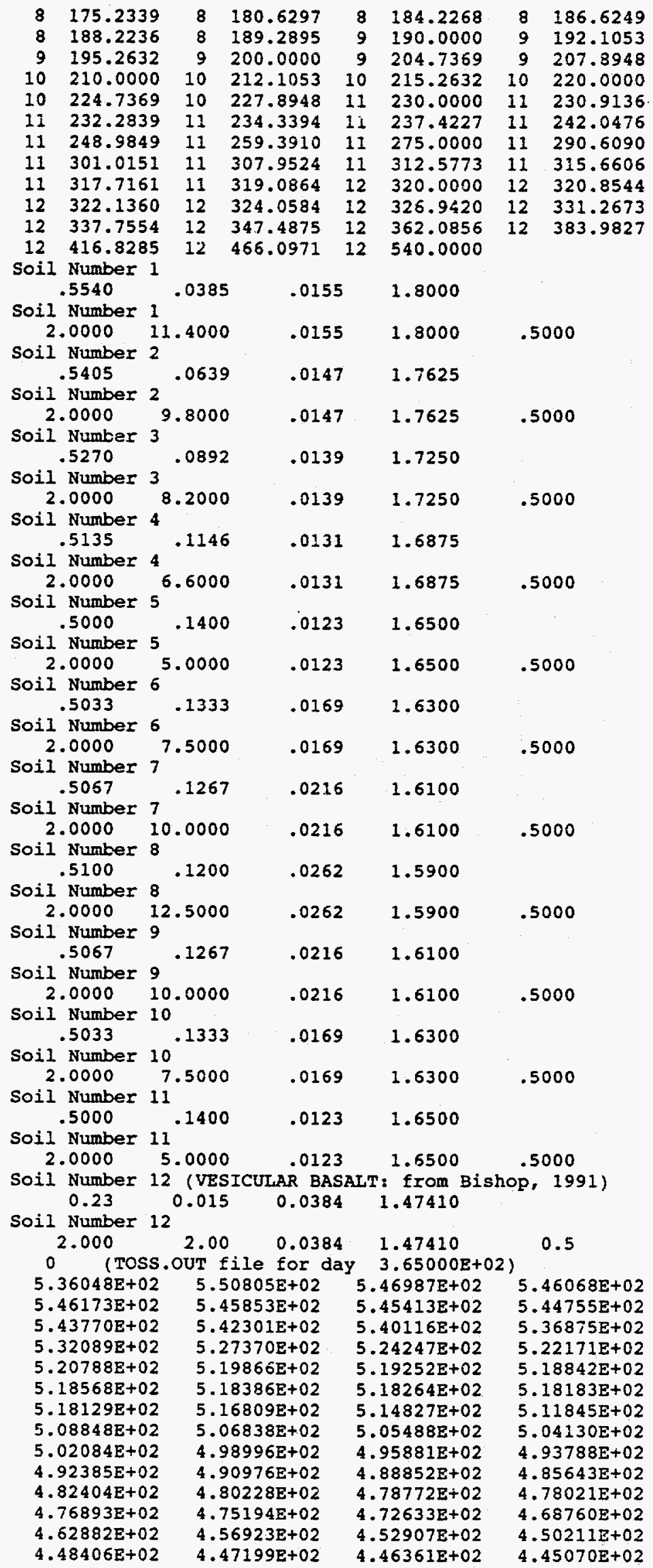

NDAY (UNSAT-H V2.01) Head Values 


\begin{tabular}{|c|c|c|c|}
\hline $4.43126 \mathrm{~B}+02$ & $4.40197 \mathrm{~B}+02$ & 4. $37250 \mathrm{E}+02$ & $4.35276 \mathrm{E}+02$ \\
\hline $\begin{array}{l}4.33881 E+02 \\
4.23350 E+02\end{array}$ & $4.21077 \mathrm{E}+02$ & $4.19466 \mathrm{E}+02$ & $4.18301 \mathrm{E}+02$ \\
\hline $4.16554 \mathrm{E}+02$ & $4.13932 \mathrm{E}+02$ & $4.10001 E+02$ & $4.04114 \mathrm{E}+02$ \\
\hline $3.95323 \mathrm{E}+02$ & $3.82289 \mathrm{E}+02$ & $3.63241 \mathrm{E}+02$ & $3.44986 \mathrm{E}+02$ \\
\hline $3.33305 \mathrm{E}+02$ & $3.25734 E+02$ & $3.20782 E+02$ & $3.17522 \mathrm{E}+02$ \\
\hline $3.15367 \mathrm{E}+02$ & $3.13938 \mathrm{E}+02$ & $3.13030 \mathrm{E}+02$ & $3.10450 \mathrm{E}+02$ \\
\hline $3.06610 \mathrm{E}+02$ & $3.00914 E+02$ & $2.95293 \mathrm{E}+02$ & $2.91585 \mathrm{E}+02$ \\
\hline $2.89207 \mathrm{E}+02$ & $2.86898 \mathrm{E}+02$ & $2.83450 \mathrm{E}+02$ & $2.78308 \mathrm{E}+02$ \\
\hline $2.73202 \mathrm{E}+02$ & $2.69817 \mathrm{E}+02$ & $2.67607 \mathrm{E}+02$ & $2.66661 E+02$ \\
\hline $2.65244 \mathrm{E}+02$ & $2.63121 E+02$ & $2.59941 \mathrm{~B}+02$ & $2.55185 \mathrm{E}+02$ \\
\hline $2.48075 \mathrm{~B}+02$ & $2.37463 \mathrm{E}+02$ & $2.21644 \mathrm{E}+02$ & $2.05918 \mathrm{E}+02$ \\
\hline $1.95473 E+02$ & $1.88524 \mathrm{E}+02$ & $1.83897 \mathrm{E}+02$ & $1.80813 \mathrm{E}+02$ \\
\hline $1.78759 \mathrm{E}+02$ & $1.77390 \mathrm{~B}+02$ & $1.76490 \mathrm{E}+02$ & $1.75866 \mathrm{E}+02$ \\
\hline $1.74948 \mathrm{E}+02$ & $1.73606 \mathrm{E}+02$ & $1.71672 \mathrm{E}+02$ & $1.68940 \mathrm{E}+02$ \\
\hline $1.65190 \mathrm{E}+02$ & $1.60252 \mathrm{E}+02$ & $1.54105 \mathrm{E}+02$ & $1.47005 E+02$ \\
\hline $1.39544 \mathrm{E}+02$ & $1.32618 \mathrm{E}+02$ & 1. $28942 \mathrm{E}+02$ & \\
\hline 1500.0 & 6.0 & 45.0 & \\
\hline
\end{tabular}


-
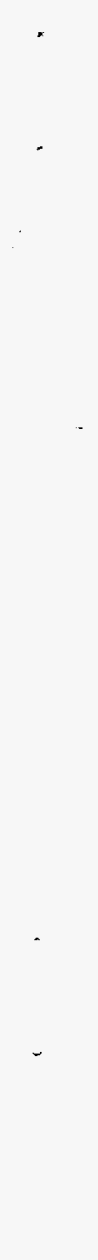

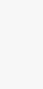

更

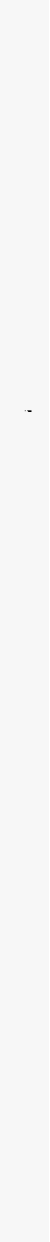




\section{Distribution List}

Off-Site

D. J. Alexander

U. S. Department of Energy

Forrestal Bldg., MS RW-23-2

Washington, DC 20585

R. G. Baca

Center for Nuclear Waste Repository Analyses

Southwest Research Institute

6220 Culebra Rd.

P. O. Drawer 28510

San Antonio, TX 78228-0516

W. Barrish

CGISS Dept. MG 206

Boise State University

Boise, ID 83725

J. S. Baldwin

Martin Marietta

Central Waste Management

Oak Ridge, TN 37831

\section{A. J. Baker}

Engineering Science and Mechanics

University of Tennessee

Knoxville, TN 37996-2030

A. K. Bhattacharyya

Department of Environmental Resources

Bureau of Radiation Protection

P. O. Box 2063

Harrisburg, PA 17120

K. H. Birdsell

Los Alamos National Laboratory

P. O. Box 2063

Harrisburg, PA 17120

T. N. Blandford

HydroGeoLogic, Inc.

1165 Herndon Pkwy, Suite 900

Herndon, VA, 22070

G. Bloomsburg

Agriculture Engineering Department

University of Idaho

Moscow, ID 83843

A. Bumb

Fluor Daniel, Inc.
100 Fluor Daniel Drive

Greenville, SC 296707

T. C. Chee

U. S. Department of Energy

Research and Management Division

DP-123, A237

Germantown, MD 20545

D. L. Chery, Jr.

U. S. Nuclear Regulatory Commission MS-4H3

Washington, DC 20555

J. N. Chung

Mechanical and Material Engineering

Washington State University

Pullman, WA 99164-2920

R. B. Codell

U. S. Nuclear Regulatory Commission

MS-4H3

Washington, DC 20555

J. R. Cook

Westinghouse Savannah River Company

Savannah River Laboratory

P. O. Box 616, Bldg. 773-43A

Aiken, SC 29802

J. C. Corey

Westinghouse Savannah River Site

P. O. Box A

Aiken, SC 29808

S. Cullen

Geraghty and Miller, Inc.

5425 Hollister Ave. Suite 100

Santa Barbara, CA 93111

M. Cunnane

Golder Associates, Inc.

4104 148th Avenue NE

Redmond, WA 98052 
P. A. Davis

Sandia National Laboratories

Division 6416

P. O. Box 5800

Albuquerque, NM 87185

P. Dickman

U. S. Department of Energy

Waste Management Project Office

P. O. Box 14100

Las Vegas, NV 89114

M. R. Dolenc

Reynolds Electrical and Engineering Co.

P. O. Box 98521

Las Vegas, NV 89193-8521

F. H. Dove

IT Corporation

5301 Central Ave, N. E., Suite 700

Albuquerque, NM 87108

R. R. Eaton

Sandia National Laboratories

Fluid Mechanics and Heat Transfer Div.

Albuquerque, NM 87185

M. Ebra

Westinghouse Savannah River Company

Environmental Restoration Program

P. O. Box 616

Aiken, SC 29802

A. 1. El-Kadi

Univ. of Hawaii at Manoa

Dept. of Geology and Geophysics

2525 Correa Road

Honolulu, HW 96822

C. G. Enfield

U. S. Environmental Protection Agency

Robert S. Kerr Environmental Lab

P. O. Box 1198

Ada, OK 74820

M. J. Fayer

Pacific Northwest Laboratory

P. O. Box 999, MS K6-77

Richland, WA 99352
J. 1. Finnie

Civil Engineering Department

University of Idaho

Moscow, ID 83843

R. A. Freeze

Department of Geological Sciences

University of British Columbia

Vancouver, BC V6T 2B4, Canada

G. W. Gee

Pacific Northwest Laboratory

P. O. Box 999, MS K6-77

Richland, WA 99352

T. C. Gunderson

Los Alamos National Laboratory

P. O. Box 1663, MS K491

Los Alamos, NM 87545

D. Hillel

Dept. of Plant and Soil Science

University of Massachusetts

12A Stockbridge Hall

Amberst, MA 01003

C. Y. Hung

U. S. Environmental Protection Agency

Office of Radiation Programs, ANR-460

401 M Street, S. W.

Washington, DC 20460

P. S. Huyakorn

HydroGeoLogic, Inc.

1165 Herndon Pkwy, Suite 900

Herndon, VA 22070

V. Ichimura

Chem-Nuclear Systems

P. O. Box 726

Barnwell, SC 29182

B. Izadi

Agricultural Engineering Dept.

Univ. of Idaho

Moscow, ID 83843 
T. L. Jones

Department of Agronomy and Horticulture New Mexico State University

Las Cruces, NM 88003-0003

W. A. Jury

Department of Soils

University of California at Riverside

Riverside, CA 90024

P. Kearl

Oak Ridge National Laboratory

Grand Junction Office

Grand Junction, CO 81502

K. Kersch

SAIC, Inc.

101 Convention Ctr. Drive, Suite 407

Las Vegas, NV 89109

C. T. Kincaid

Pacific Northwest Laboratory

P. O. Box 999, MS K6-77

Richland, WA 99352

R. G. Knowlton

Sandia National Laboratories

P. O. Box 5800, Div 6416

Albuquerque, NM 87185

C. P. Liou

Civil Engineering Department

University of Idaho

Moscow, ID 83843

J. T. McCord

Sandia National Laboratories

Division 6416

Albuquerque, NM 85185-5800

L. M. McDowell-Boyer

Oak Ridge National Laboratory

Grand Junction Office

Grand Junction, CO 81502

C. McLane

ENVIRON International Corp.

4350 N. Fairfax Dr., Suite 300

Arlington, VA 22203
D. B. Mclaughlin

Department of Civil Engineering

Massachusetts Institute of Technology

Room 48-329

Cambridge, MA 02139

S. A. Mizell

Desert Research Institute

P. O. Box 60220

Reno, NV 89506

D. J. Mulla

Soils Department

Washington State University

Pullman, WA 99164

S. P. Neuman

Dept. of Hydrology and Water Resources

University of Arizona

Tucson, AZ 85721

T. J. Nicholson

U. S. Nuclear Regulatory Commission

Division of Engineering Safety

MS NL-005

Washington, DC 20555

J. W. Hyhan

Los Alamos National Laboratory

P. O. Box 1663

Los Alamos, NM 87545

F. L. Parker

4400 Iroquois

Nashville, TN 37205

D. M. Peterson

INTERA Associates, Inc.

8100 Mountain Road NE, Suite 213

Albuquerque, NM

O. A. Plumb

Mechanical and Material Engineering

Washington State University

Pullman, WA 99164-2920

J. Pope

Westinghouse Savannah River Company

Environmental Restoration Program

P. O. Box 616

Aiken, SC 29802

R. W. Prindle 
Sandia National Laboratories

Division 6312

P. O. Box 5800

Albuquerque, NM 87185

\section{Reeves}

INTERA Associates, Inc.

6850 Austin Ctr. Blvd., Suite 300

Austin, TX 78731

\section{L. Rockhold}

Pacific Northwest Laboratory

P. O. Box 999, MS K6-77

Richland, WA 99352

V. C. Rogers

Rogers \& Associates Engineering Corp.

P. O. Box 330

Salt Lake City, UT 84110

A. K. Runchal

ACR, Inc.

1931 Stradella

Los Angeles, CA 90077

B. Sagar

Center for Nuclear Waste Repository Analyses

Southwest Research Institute

6220 Culebra Rd.

P. O. Drawer 28510

San Antonio, TX 78228-0516

S. G. Schmelling

U. S. Environmental Protection Agency

Robert S. Kerr Environmental Lab

P. O. Box 1198

Ada, OK 74820

M. Silberberg

U. S. Nuclear Regulatory Commission

Office Nuclear Regulatory Research

Washington, DC 20555

J. L. Smoot

Pacific Northwest Laboratory

P. O. Box 999, MS K6-77

Richland, WA 99352
C. J. Suen

Brookhaven National Laboratory

Nuclear Waste and Materials Technology Division:

Upton, Long Island, NY 11973

R. J. Starmer

ERM-Program Management Corp

7926 Jones Branch Drive, Suite 210

McLean, VA 22102

Technical Library

Los Alamos National Laboratory

P. O. Box 1663

Los Alamos, NM 87545

Technical Library

Oak Ridge National Laboratory

P. O. Box X

Oak Ridge, TN 37830

Technical Library

Savannah River Laboratory

P. O. Box 616

Aiken, SC 29802

B. Troutman

Dames and Moore, Inc.

1970 E. 17th St., Suite 111

Idaho Falls, ID 83401

B. J. Travis

Los Alamos National Laboratory

P. O. Box 1663

Los Alamos, NM 87545

S. W. Tyler

Water Resources Center

Desert Research Institute

P. O. Box 60220

Reno, NV 89506-0220

B. L. Roberts

EG\&G Rocky Flats, Inc.

P. O. Box 464

Golden, CO 80402-0464

M. T. van Genuchten

USDA-ARS, U. S. Salinity Laboratory

4500 Glenwood Drive

Riverside, CA 92501

P. van der Heijde 
International Groundwater Modeling Center Colorado School of Mines

Golden, CO 80401-1887

J. Wang

Lawrence Berkeley Laboratory

Earth Sciences Division

1 Cyclotron Road

Berkeley, CA 94720

A. W. Warrick

University of Arizona

Dept. of Soil and Water Science

Tuscon, AZ 85721

E. P. Weeks

U. S. Geological Survey

Federal Center, MS 413

Denver, CO 80225

M. Weinstein

U. S. Nuclear Regulatory Commission

MS NL/S-260

Washington, DC 20555

P. J. Wierenga

University of Arizona

Dept. of Soil and Water Science

Tucson, AZ 85721

D. C. Wiggert

Michigan State University

A120 Engineering Research Complex

East Lansing, Michigan 48824

J. L. Wilson

New Mexico Institute of Mining and Technology

Dept. of Geosciences

Socorro, NM 87801
Westinghouse Hanford Company

P. O. Box 1970

Richland, WA 99352

J. D. Davis, MS H4-54

R. Khaleel, MS H4-54

J. C. Sonnichsen, MS H4-54

A. Yu

Westinghouse Savannah River Company

Savannah River Laboratory

P. O. Box 616

Aiken, SC 29802

$\underline{\text { On-Site }}$

DOE-ID

M. C. Bennett

EG\&G Idaho, Inc.

R. C. Amett

J. M. Hubbell

J. A. Logan (10)

S. O. Magnuson

J. N. McCarthy

J. W. McConnell

R. L. Nitschke

H. D. Nguyen

R. R. Seitz

J. B. Sisson

C. S. Smith

A. J. Sondrup

INEL Technical Library

Westinghouse Idaho Nuclear Co., Inc.

T. R. Thomas

U. S. Geological Survey

L. J. Mann

L. D. Cecil 